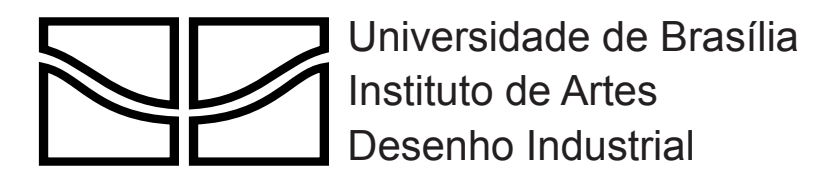

\title{
Objetos de Aprendizagem
}

\author{
Adriano de Oliveira Santos Ayub \\ Daniel Siqueira Carvalho \\ Ítalo Hauer Teixeira
}
Profa. Virgínia Tiradentes
Prof. Tiago Barros
Orientadores





\section{Resumo}

Este trabalho tem como objetivo enfatizar a necessidade da programação visual na utilização dos objetos de aprendizagem do RIVED (Rede Interativa Virtual de Educação). Para isto, realizou-se o estudo e análise da padronização visual dos atuais objetos de aprendizagem do RIVED, com foco no público alvo, e análise intrínseca da usabilidade de suas animações e simulações interativas. Uma vez definidos os pontos críticos, foi elaborada uma lista de pré-requisitos que suprisse as falhas observadas. Em seguida, foi proposto um padrão visual para os módulos e objetos de aprendizagem e criados dois novos objetos de aprendizagem nas áreas de Física e Artes, onde a programação visual foi tratada com o mesmo grau de importância que o design instrucional, o conteúdo e a usabilidade, visando a eficiência e a eficácia da comunicação e, conseqüentemente, o aprendizado. 


\begin{abstract}
This work is aimmed to emphasize the necessity of visual programming on the use of RIVED's (Virtual Interactive Net of Education) learning objects. For this, the study of visual standardization of current RIVED's learning objects were done, with focus on the aimmed public, and intrinsic analysis of the usability of its animations and interactive simulations. As the critical points were defined, it was elaborated a list of the prerequisite in order to resolve the observed problems. After that, a visual standard for the modules and learning objects were proposed and two new learning objects, in the areas of Physics and Arts, were created. The visual programming was considered of the same degree of importance as the instrucional design, the content and the usability. Hence, the efficiency and the effectiveness of the communication and, consequently, the learning were maximized.
\end{abstract}




\section{Sumário}

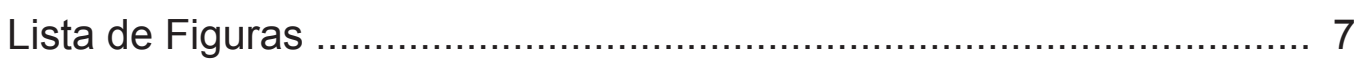

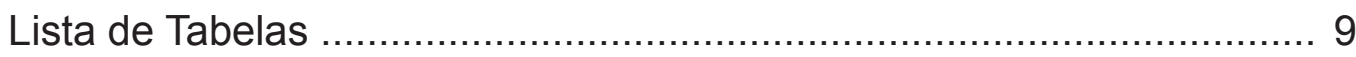

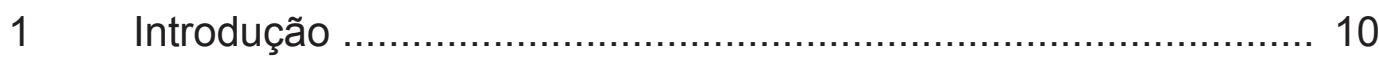

$2 \quad$ Análise e coleta de dados ..................................................... 11

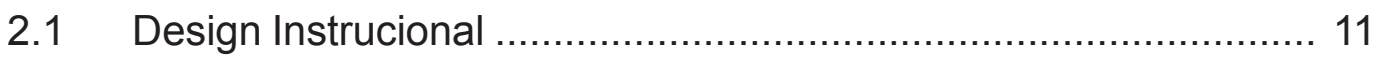

2.2 O programa RIVED ............................................................ 11

2.3 Padrão visual proposto pelo RIVED …………........................ 13

2.3.1 Análise do padrão HTML e elementos gráficos propostos ......... 16

2.4 Análise das animações .......................................................... 20

2.4.1 Ergonomia, ergonomia cognitiva e sistemas informatizados ....... 20

2.4.2 Análise de usabilidade intrínseca - Estudo de casos ................. 21

2.5 O design gráfico como facilitador do aprendizado ....................... 27

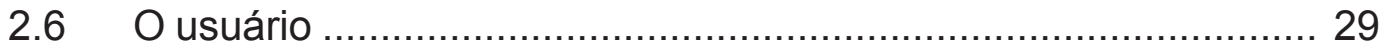

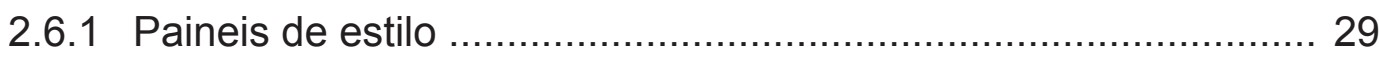

3 Definição do problema ............................................................... 33

3.1 Lista de pré-requisitos para a elaboração do projeto ................... 33

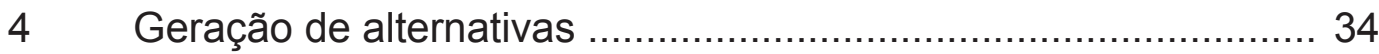

4.1 Alternativas para o padrão HTML …………............................ 34

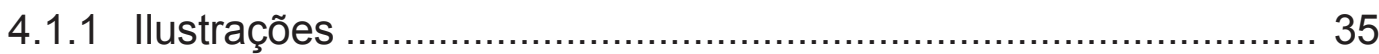

4.1.2 Aplicações no formato padrão …............................................. 37

4.2 Alternativas para os botões de navegação ................................. 52

5 Objeto 1 - Escala musical pitagórica ......................................... 54

5.1 Referências estéticas da Grécia Antiga ................................. 54

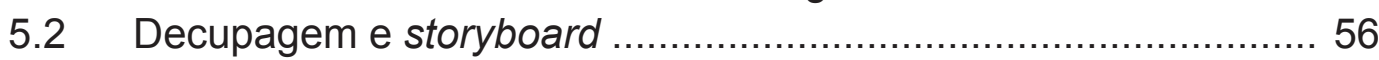

5.3 Concepção dos personagens ................................................ 58

5.3.1 Modelagem 3D do personagem Pitágoras ................................ 61

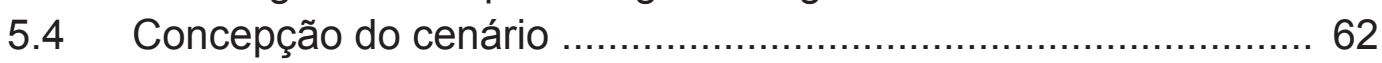

5.5 Som para a animação ............................................................. 64

5.6 Objeto de aprendizagem final aplicado ao padrão HTML ............ 65

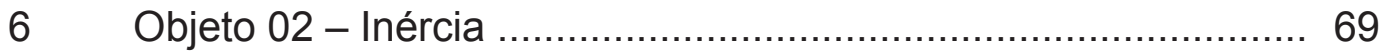

6.1 Pesquisa e concepção dos personagens …………………....... 69 


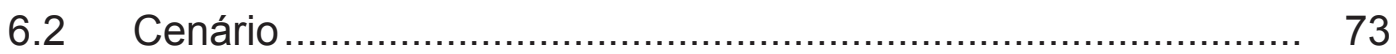

6.3 Objeto de aprendizagem final aplicado ao padrão HTML ......... 73

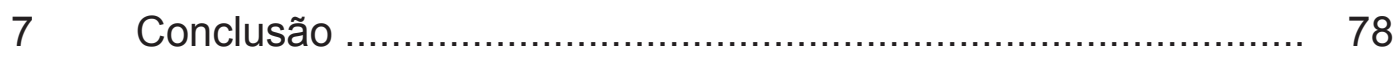

$8 \quad$ Referências bibliográficas …............................................... 79 


\section{Lista de Figuras}

Figura 2.1: Padrão cromático por disciplinas 13

Figura 2.2: Análise de área para o padrão RIVED 14

Figura 2.3: Análise de área para o padrão RIVED 14

Figura 2.4: Análise de área para o padrão RIVED 14

Figura 2.5: Elementos gráficos propostos $\quad 15$

Figura 2.6: Elementos gráficos propostos $\quad 15$

Figura 2.7: Elementos gráficos propostos $\quad 16$

Figura 2.8: Padrão do HTML proposto 17

Figura 2.9: Elementos gráficos propostos 18

Figura 2.10: Módulo analisado - grupo I 24

Figura 2.11: Módulo analisado - grupo II 24

Figura 2.12: Módulo analisado - grupo III 25

Figura 2.13: Gráfico de ocorrência de botões para navegação 26

Figura 2.14: Botões para navegação - estudo de similares 27

Figura 2.15: Painel de estilo para ambientes educacionais $\quad 30$

Figura 2.16: Painel de estilo estudantes $\quad 31$

Figura 4.1: Cores padrões para disciplinas $\quad 35$

Figura 4.2: Lápis e fita $\quad 35$

Figura 4.3: Lápis e fita 36

Figura 4.4: Mouse e lápis $\quad 36$

Figura 4.5: Ícones $\quad 37$

Figura 4.6: Lápis USB $\quad 37$

Figura 4.7: Proposta 1

Figura 4.8: Proposta 2

Figura 4.9: Proposta $3 \quad 40$

Figura 4.10: Proposta 4

Figura 4.11: Proposta 5

Figura 4.12: Proposta 6

Figura 4.13: Proposta $7 \quad 44$

Figura 4.14: Proposta $8 \quad 45$

Figura 4.15: Proposta $9 \quad 46$

Figura 4.16: Proposta $10 \quad 47$

Figura 4.17: Proposta $11 \quad 48$

Figura 4.18: Proposta $12 \quad 49$

Figura 4.19: Aplicação de cores da alternativa escolhida 52

Figura 4.20: Alternativas para botões de navegação 52

Figura 4.21: Alternativa selecionada 53

Figura 5.1: Painel de estilo baseado na cultura grega 55

Figura 5.2: Cena 1

Figura 5.3: Cena 2

Figura 5.4: Cena3 $\quad 57$

Figura 5.5: Cena 4

Figura 5.6: Geração de alternativas para os personagens 59 
Figura 5.7: Personagens digitalizados e com padrão cromático definido $\quad 59$

Figura 5.8: Animação 2D dos ferreiros $\quad 60$

Figura 5.9: Processo de modelagem subdivisão de polígonos 61

Figura 5.10: Testes de acabamento 62

Figura 5.11: Acabamento final $\quad 62$

Figura 5.12: Referência para cenário 63

Figura 5.13: Cenário final 63

Figura 5.14: Faixas multipistas $\quad 64$

Figura 5.15: Cena $1 \quad 65$

Figura 5.16: Cena $2 \quad 65$

Figura 5.17: Cena $3 \quad 66$

Figura 5.18: Cena $4 \quad 66$

Figura 5.19: Cena $5 \quad 67$

Figura 5.20: Cena 6 - erro 67

Figura 5.21: Cena 6 - acerto 68

Figura 6.1: Referência usada na concepção do personagem Aristóteles $\quad 70$

Figura 6.2: Rascunhos para o personagem Aristóteles $\quad 70$

Figura 6.3: Conceito do Personoagem Aristóteles $\quad 70$

Figura 6.4: Animação do personagem Aristóteles $\quad 70$

Figura 6.5: Referências usadas na concepção do personagem Galileu $\quad 71$

Figura 6.6: Rascunhos para o personagem Galileu $\quad 71$

Figura 6.7: Conceito do Personoagem Galileu $\quad 71$

Figura 6.8 - Animação do personagem Galileu 71

Figura 6.9: Referências usadas na concepção do personagem Newton 72

Figura 6.10: Rascunhos para o personagem Newton $\quad 72$

Figura 6.11: Conceito do Personoagem Newton 72

Figura 6.12: Animação do personagem Newton 12

Figura 6.13: Referência usada na concepção do cenário 73

Figura 6.14: Cenário desenvolvido para interagir com os personafens 2D 73

Figura 6.15: Tela $1 \quad 74$

Figura 6.16: Tela $2 \quad 74$

Figura 6.17: Tela $3 \quad 75$

Figura 6.18: Questão $1 \quad 76$

Figura 6.19: Questão $2 \quad 76$

Figura 6.20: Questão $3 \quad 77$

Figura 6.21: Questão $4 \quad 77$ 


\section{Lista de Tabelas}

Tabela 2.1: Análise do HTML - outubro $2006 \quad 17$

Tabela 2.2: Análise dos elementos gráficos propostos 19

Tabela 2.3: Análise quantitativa da incidência de padronização para os 19 objetos disponíveis no RIVED

Tabela 2.4: Critérios ergonômicos de usabilidade 22

Tabela 2.5: Representação por números dos elementos dispersos pelos 25 módulos de ensino 


\section{Introdução}

A implementação das novas tecnologias multimídias e simulações computadorizadas no ambiente educacional podem contribuir de forma efetiva com a aprendizagem. Disponibilizar esses recursos didáticos por meio da internet possibilita atender a demanda de professores e alunos.

O RIVED (Rede Interativa Virtual de Educação) é um programa da Secretaria de Educação a Distância - SEED, que tem por objetivo a produção de conteúdos pedagógicos digitais, na forma de objetos de aprendizagem. De acordo com o RIVED um objeto de aprendizagem é qualquer recurso que possa ser utilizado para dar suporte ao aprendizado. Tais objetos devem estimular o raciocínio e o pensamento crítico dos estudantes, associando o potencial da informática às novas abordagens pedagógicas. O RIVED promove a produção e publica na Internet os conteúdos digitais para acesso gratuito.

Por se tratar de um programa recente, os módulos e objetos produzidos pelo RIVED ainda não estão adequados do ponto de vista da programação visual. Desta forma, este projeto visa contribuir com a proposta educacional do RIVED por meio da intervenção no design dos padrões de módulos, e objetos de aprendizagem, além da criação de dois novos objetos de aprendizagem nas áreas de Física (inércia) e Artes (escala musical pitagórica).

Os conteúdos dos objetos foram propostos pelo físico Flávio Ambrosio Campos, especialista de área disciplinar do programa RIVED.

Levando em conta as diferenças individuais no aprendizado, a motivação para o estudo, a transformação do ambiente educacional tradicional para um ambiente virtual, a faixa etária do usuário e seu estilo de vida no contexto da sociedade atual, este projeto visa tornar os objetos de aprendizagem mais atrativos, lúdicos e que atinjam os anseios dos estudantes e educadores. 


\section{Análise e coleta de dados}

Para listar os pré-requisitos necessários à elaboração do presente projeto é importante entender o processo de criação dos objetos de aprendizagem. Alguns conceitos serão introduzidos para o entendimento deste processo (design instrucional e Ergonomia). É importante, também, conhecer o trabalho desenvolvido pelo programa RIVED, a metodologia adotada, o ponto de inserção do designer neste contexto, e o usuário final. Outro ponto fundamental de estudo é a análise dos padrões visuais propostos pelo RIVED e a análise intrínseca da usabilidade das animações e simulações.

\subsection{Design Instrucional}

É necessário o entendimento do conceito de design instrucional uma vez que servirá de ferramenta para elaboração do conteúdo dos objetos de aprendizagem.

O design instrucional descreve uma variedade de métodos de instrução (diferentes formas de facilitar o aprendizado e desenvolvimento humanos), e quando usar - ou não usar - cada um destes métodos com objetivo de proporcionar ao aprendiz uma experiência de aprendizado mais agradável e satisfatória.

Andrea Cristina Filatro em seu livro Design instrucional contextualizado: educação e tecnologia compreende design instrucional como:

"A ação intencional e sistemática de ensino que envolve o planejamento, o desenvolvimento e a utilização de métodos, técnicas, atividades, materiais, eventos e produtos educacionais em situações didáticas especificas, a fim de facilitar a aprendizagem humana a partir dos princípios de aprendizagem e instrução conhecidos."

Deve-se ressaltar que o design instrucional se distingue da ciência da informação uma vez que o usuário participa de forma ativa na construção de seu conhecimento e não apenas aos fluxos de acesso aos conteúdos.

\subsection{O programa RIVED}

O projeto RIVED (Rede Interativa Virtual de Educação), ainda em fase de implantação, é um projeto inovador - utiliza animações e simulações para exploração de fenômenos científicos e conceitos, muitas vezes inviáveis ou inexistentes nas escolas por questões econômicas e/ou de segurança, disponibilizados gratuitamente pela página do projeto RIVED na internet (http://rived.proinfo.mec.gov.br). 
Por ser ainda muito recente (criado em 2004), o conteúdo disponibilizado abrange uma pequena parte do exigido pelo ensino médio. Daí a possibilidade de apresentar novas fórmulas de concepção dos módulos de ensino.

Segundo informações coletadas na página do RIVED, os módulos são elaborados contando com o professor para facilitar e dar suporte aos alunos. Os professores desempenham papéis importantes na implementação de tecnologia nas salas de aula. Eles decidem sobre o como, quando, e como usar a tecnologia em sala. A reutilização dos objetos de aprendizagem oferece uma forma eficiente de facilitar a instrução. Os objetos de aprendizagem podem ser readaptados para satisfazer diferentes tipos de usuários (WILEY, 2000), eles podem ser parte de uma estratégia educacional, como sugerido no módulo, ou pode ser utilizado individualmente, de acordo com a necessidade do professor. Para encorajar o melhor uso dos objetos de aprendizagem, o guia do professor que acompanha os módulos, sugere várias atividades complementares, práticas de avaliação e material de referência.

O RIVED possui uma metodologia definida para a criação dos módulos, como segue (NASCIMENTO; MORGADO, 2003):

Design instrucional - Os especialistas das áreas disciplinares consultam o mapeamento de conteúdos e selecionam o tópico do novo módulo. A equipe pedagógica define os objetivos educacionais e elaboram as respectivas estratégias educacionais. $\mathrm{O}$ designer instrucional interage com os especialistas a fim de guiar sobre a seqüência instrucional e o nível cognitivo requerido nas atividades. Os objetivos e as atividades são descritos no documento intitulados: General Design (GD).

General design dos módulos - O documento, General design, elaborado é submetido às outras equipes para obter críticas e feedback. A revisão do GD pelas demais equipes consiste em comentários sobre:

a) o design do programa e a abordagem pedagógica;

b) questões referentes ao uso apropriado da tecnologia;

c) sugestões para diferentes atividades ou mídia;

d) chamar a atenção para materiais similares existentes;

e) adequação do modulo às variadas audiências.

Interação das equipes - Os especialistas de conteúdo revisam o design original após receber feedback das outras equipes. Passam a descrever as especificações para cada objeto de aprendizagem, na forma de scripts e roteiros de tela, para o grupo de técnicos desenvolver os produtos desejados.

Produção de objetos de aprendizagem - O grupo de técnicos produz os objetos de aprendizagem. Durante esta fase, os especialistas de conteúdo, o designer instrucional, e os técnicos interagem bastante para evitar erros. 
Guia do professor - Os especialistas em conteúdo criam o guia do professor para cada objeto de aprendizagem.

Módulos web - Os objetos de aprendizagem são organizados nos módulos e publicados na web.

Observa-se que a metodologia proposta não elege a programação visual e todo seu universo (usabilidade, tipografia, padronização, cores, hierarquia de informação, grades de construção, etc) como um fator relevante na construção de um objeto de aprendizagem. É importante ressaltar que os designers gráficos são incluídos no "grupo de técnicos que produzem os objetos de aprendizagem", implicando na baixa qualidade, do ponto de vista da programação visual, dos objetos produzidos pelo programa RIVED.

\subsection{Padrão visual proposto pelo RIVED}

Apesar da ausência da especificação do padrão na metodologia proposta, encontra-se no sítio do RIVED uma sugestão de padronização dos módulos, com a intenção de manter uma coerência visual entre os objetos. Essa coerência visual age como um facilitador de aprendizagem uma vez que o usuário não precisa re-aprender a usar a interface a cada objeto de aprendizagem utilizado.

Cada disciplina recebe uma cor de identificação (fig.2.1), nas barras do HTML:

. Física: azul (\#000099)

. Matemática: vermelho (\#990000)

. Química: laranja (\#FF0099)

. Biologia: verde (\#006633)

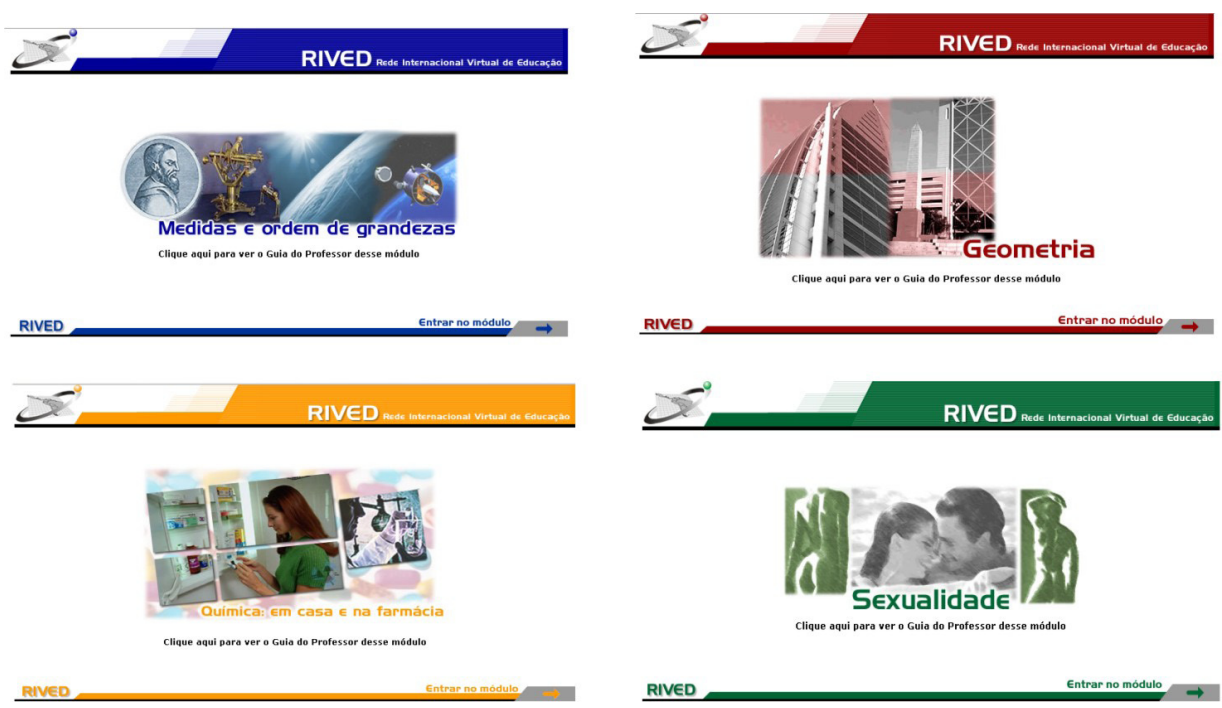

Figura 2.1 - Padrão cromático por disciplinas

São propostos tamanhos para o HTML (770px X 450px) e palco (área da animação) para as animações (700px X 400px). 


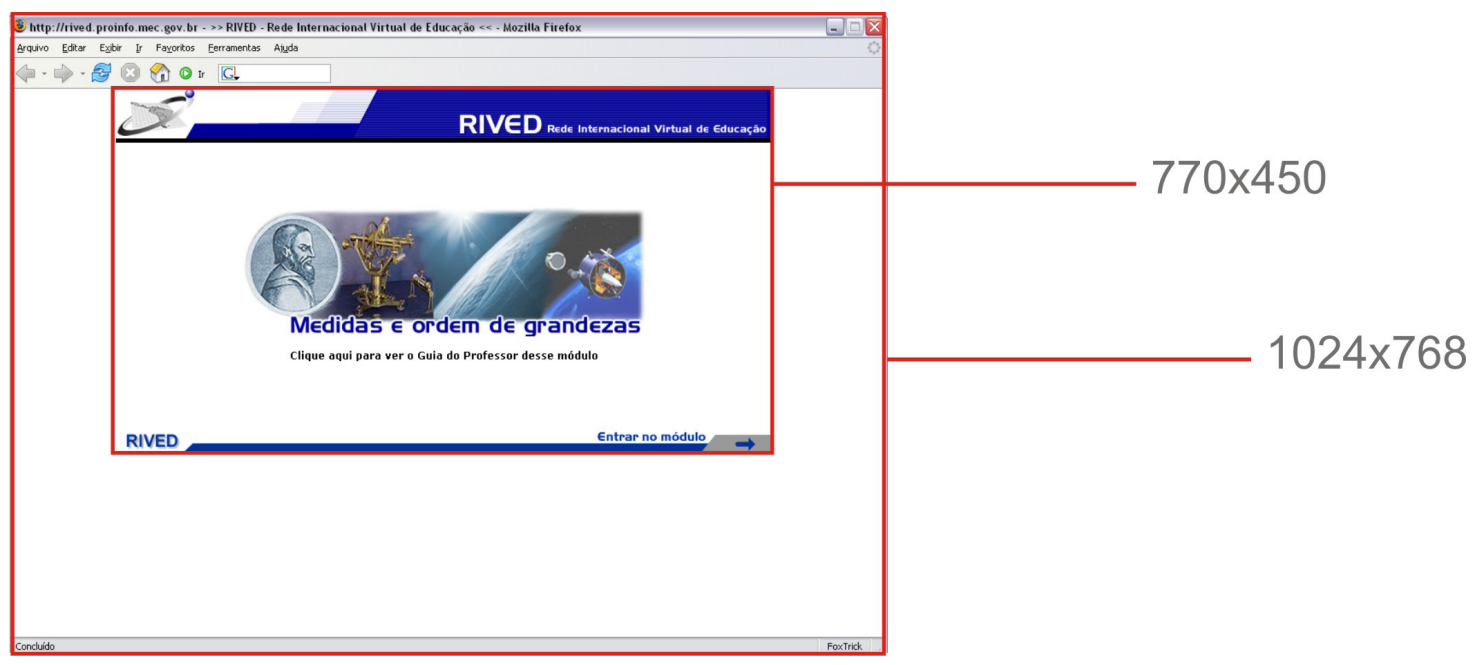

Figura 2.2 - Análise de área para o padrão RIVED

Fonte: http://rived.proinfo.mec.gov.br, outubro 2006

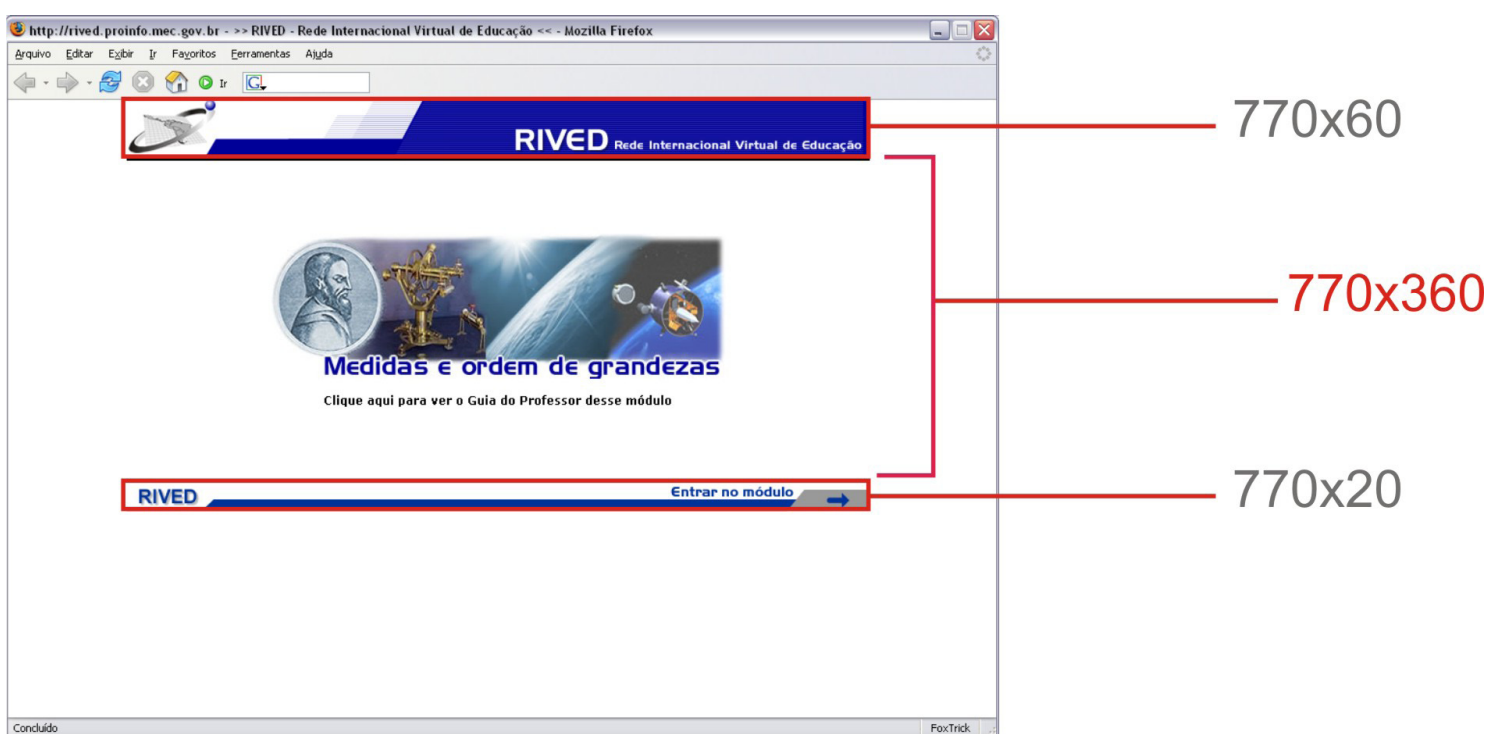

Figura 2.3 - Análise de área para o padrão RIVED

Fonte: http://rived.proinfo.mec.gov.br, outubro 2006

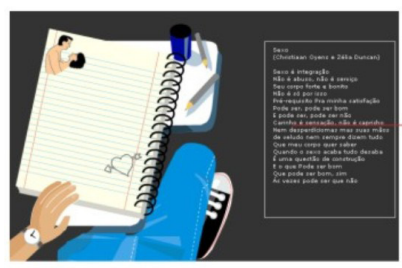

$770 \times 400$

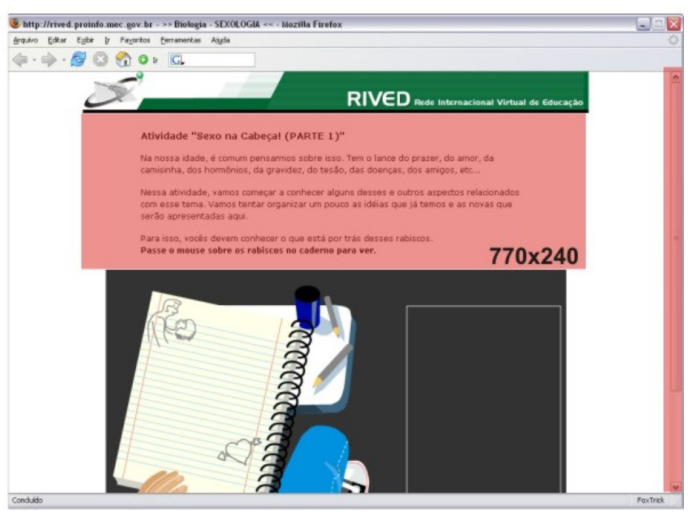

Figura 2.4 - Análise de área para o padrão RIVED Fonte: http://rived.proinfo.mec.gov.br, outubro 2006 
Tendo em vista que a altura máxima para visualização da página em um monitor $800 p x$ X 600px é prevista pelo padrão como sendo 450px, o somatório das dimensões das barras, superior e inferior, ocupam $80 \mathrm{px}$, observa-se que o padrão proposto gera naturalmente uma barra de rolagem, uma vez que o palco possui $400 \mathrm{px}$ de altura. Além disso, em vários módulos, os textos que dizem respeito ao conteúdo das atividades, também ocupam grandes áreas nas páginas e não existe um limite previsto para suas dimensões, acarretando novamente em barras de rolagens.

Alguns elementos gráficos recorrentes nos objetos são apresentados como idéias de padrões para todas atividades, botões de navegação (fig.2.5; fig.2.6), instruções implícitas e balões de fala. Aconselha-se, também, que as instruções abram no início da atividade (fig.2.7).

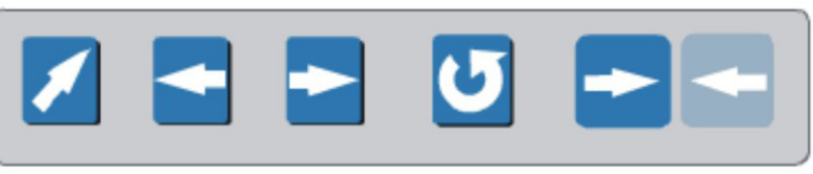

Figura 2.5 - Elementos gráficos propostos

Fonte: http://rived.proinfo.mec.gov.br, outubro 2006

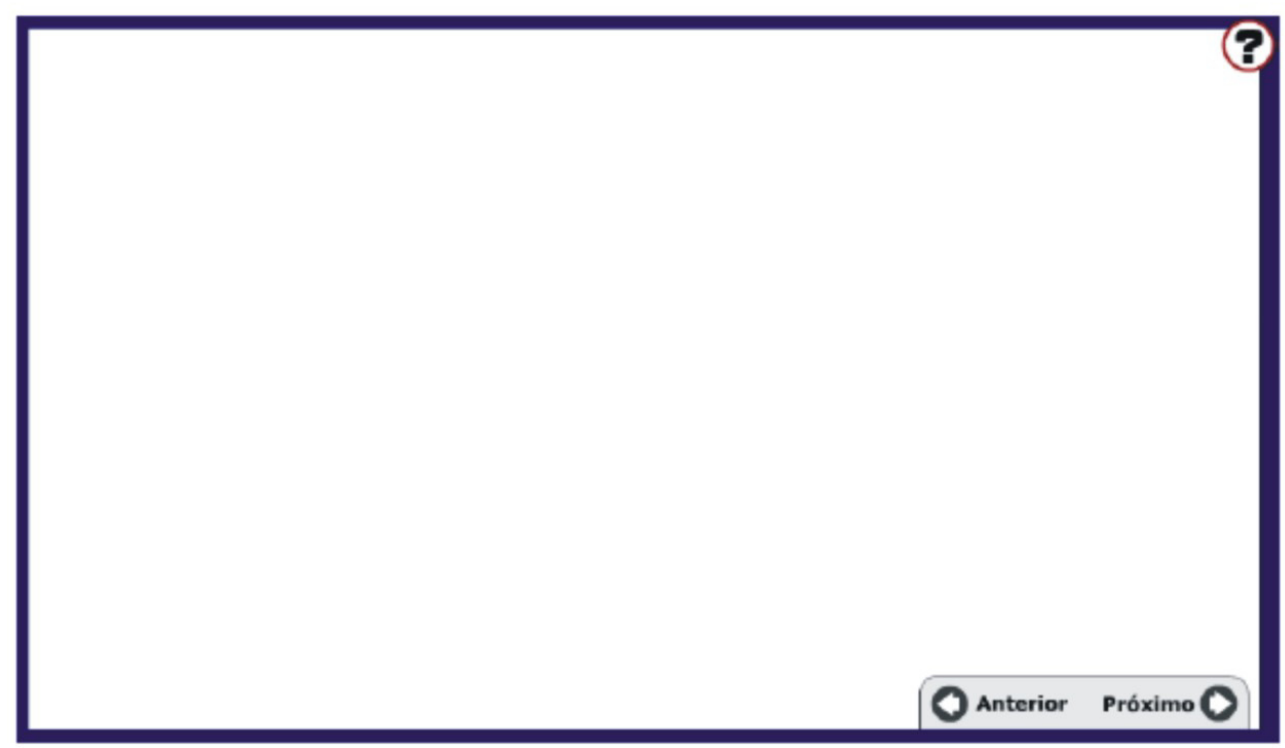

Botões de INICIAR / REINICIAR / PARAR / CONTINUAR / PAUSA.

\section{Cancelar}

\section{Pausa}

Reiniciar

Iniciar

Figura 2.6 - Elementos gráficos propostos

Fonte: http://rived.proinfo.mec.gov.br, outubro 2006 
:: INSTRUÇôES ::

1) nomon momono comonomom nomono monom momo mom nono momm nono nono nomo

2) nomon momono comonomom nomono monom momo mom nono momm nono nono nomo

3) nomon momono comonomom nomono monom momo mom nono momm nono nono nomo

4) nomon momono comonomom nomono monom momo mom nono momm nono nono nomo

5) nomon momono oomonomom nomono monom momo mom nom momm nono noiso nomo

Figura 2.7 - Elementos gráficos propostos

Fonte: http://rived.proinfo.mec.gov.br, outubro 2006

\subsubsection{Análise do padrão HTML e elementos gráficos propostos}

Para o presente projeto foi realizada uma análise do padrão HTML (fig.2.8) proposto pelo programa RIVED, adotando-se três critérios principais: funcional, semântico e formal.

O critério funcional diz respeito a algo relevante ou expressivo, que cumpre com alguma função dentro do contexto, links, informações para localização do usuário e ajuda, são exemplos de funcionalidade.

O critério semântico busca estabelecer um significado passível de interpretação entre a função exercida pelos comandos e as imagens referentes (signo).

O critério formal diz respeito à estética, visa tanto sua forma, cor, textura dimensões, como o movimento estético em que estão inseridos, por meio do qual possa detectar-se a intenção artística, o público a ser atingido e as origens culturais da manifestação estética.

A partir da conceituação descrita acima realizou-se uma análise dos pontos positivos e negativos do padrão para o HTML proposto (tab.2.1). 


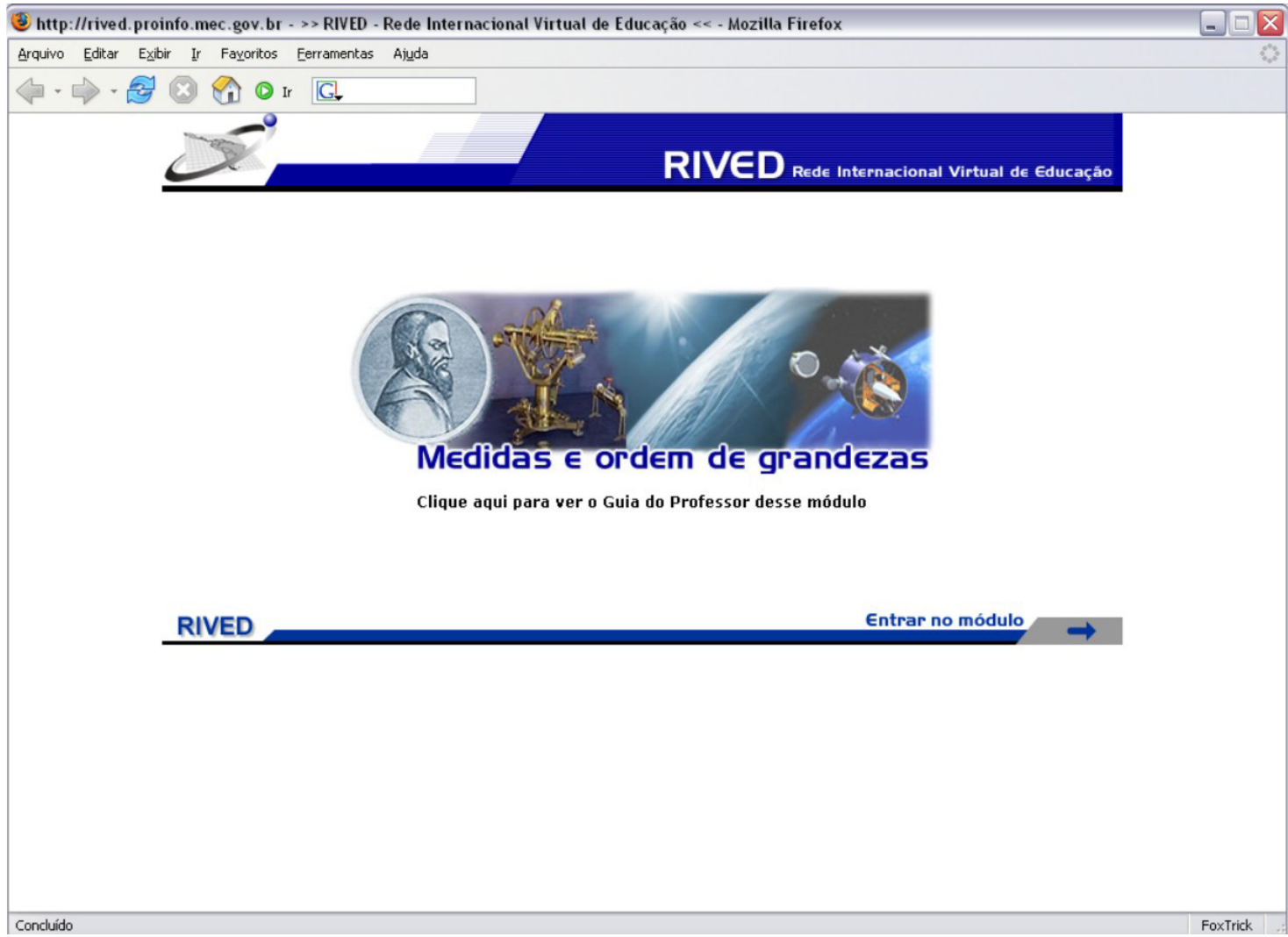

Figura 2.8 - Padrão do HTML proposto

Fonte: http://rived.proinfo.mec.gov.br, out 2006

Tabela 2.1 - Análise do HTML - outubro 2006

\begin{tabular}{|c|c|c|}
\hline Critérios & Pontos positivos & Pontos negativos \\
\hline Funcional & $\begin{array}{l}\text { Diferenciação entre as disciplinas; } \\
\text { Padronização de cor; } \\
\text {. Utilização da marca RIVED na barra } \\
\text { superior; } \\
\text {. Padronização das medidas; } \\
\text {. Padronização de fonte; } \\
\text {. Padronização de cor de fundo }\end{array}$ & $\begin{array}{l}\text {. Emprego de ilustrações para cada } \\
\text { conteúdo ocupando uma página } \\
\text { inteira; } \\
\text {. Utilização da marca RIVED na barra } \\
\text { inferior (informação repetida, já está } \\
\text { na barra superior); } \\
\text {. Não existe limite para o número de } \\
\text { atividades por módulo }\end{array}$ \\
\hline Semântico & $\begin{array}{l}\text { - Utilização das mesmas barras em } \\
\text { todos os módulos e respectivas } \\
\text { páginas }\end{array}$ & $\begin{array}{l}\text {. Pouca coerência visual entre o site } \\
\text { do RIVED e os módulos; } \\
\text {. Emprego da cor sem associar explici- } \\
\text { tamente a qual disciplina se refere }\end{array}$ \\
\hline Formal & . Limpeza visual & $\begin{array}{l}\text {. O layout não remete à educação; } \\
\text {. Falta harmonia no posicionamento } \\
\text { do símbolo, do nome RIVED e da assi- } \\
\text { natura por extenso; } \\
\text {. Solução de layout pouco criativa; } \\
\text {. Largura da barra superior; } \\
\text {. Barras inexpressivas }\end{array}$ \\
\hline
\end{tabular}

Fonte: http://rived.proinfo.mec.gov.br, 2006 
As padronizações (cor, medidas, fontes, e cor de fundo) são importantes pelo fato de manter uma coerência visual agindo como um facilitador de aprendizagem uma vez que o usuário não precisa re-aprender a usar a interface a cada objeto de aprendizagem utilizado.

O fato de não existir limite para o número de atividades por módulo é prejudicial uma vez que pode induzir a uma alta densidade informacional.

A barra superior não possui funcionalidade que justifique sua largura e afeta 0 espaço destinado às animações.

As barras superiores e inferiores não possuem nenhuma expressividade, isto é não remetem ao tema proposto pelo RIVED.
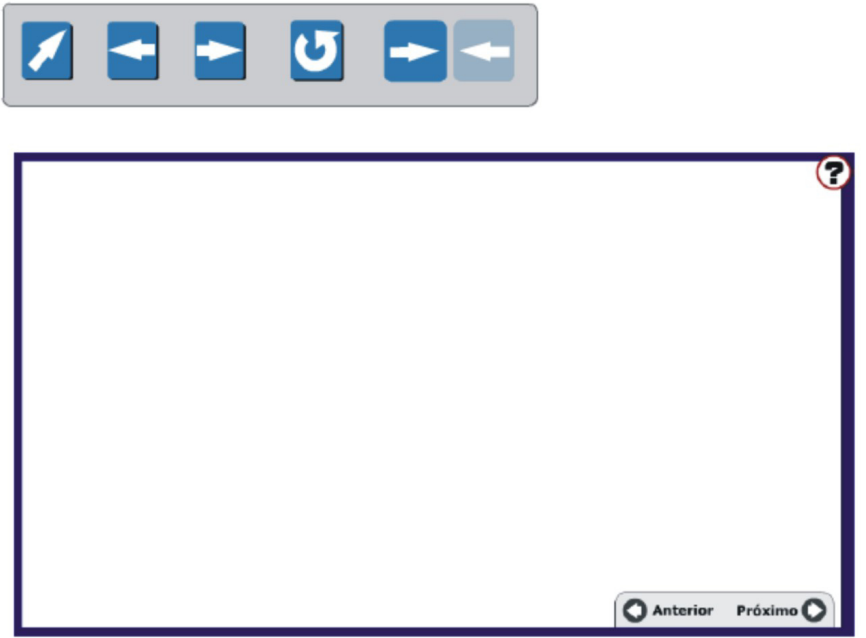

Botões de INICIAR / REINICIAR / PARAR / CONTINUAR / PAUSA.

$$
\text { Cancelar }
$$$$
\text { Pausa }
$$

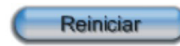

Iniciar

Figura 2.9 - Elementos gráficos propostos

Fonte: http://rived.proinfo.mec.gov.br, out 2006 
Tabela 2.2 - Análise dos elementos gráficos propostos - Outubro 2006

\begin{tabular}{|c|c|c|}
\hline Critérios & Pontos positivos & Pontos negativos \\
\hline Funcional & $\begin{array}{l}\text { Padronização de medida; } \\
\text { Padronização de fonte; } \\
\text {. Padronização dos botões de } \\
\text { navegação; } \\
\text {. Abertura automática das instruções; } \\
\text {. Padronização do botão de instruções; } \\
\text {. Instruções externas }\end{array}$ & $\begin{array}{l}\text { Padronização desnecessária do } \\
\text { balão de fala dos personagens, uma } \\
\text { vez que não gera nenhum benefício } \\
\text { ao usuário. }\end{array}$ \\
\hline Semântico & $\begin{array}{l}\text { Padronização dos botões para } \\
\text { navegação }\end{array}$ & $\begin{array}{l}\text {. Não existe relação estética nem } \\
\text { com o site nem com o padrão HTML } \\
\text { proposto; } \\
\text {. Botões pouco expressivos com } \\
\text { semelhança formal e funções } \\
\text { diferentes; } \\
\text {. Botões cancelar, pausa, reiniciar } \\
\text { e iniciar incoerentes com o padrão } \\
\text { estabelecido }\end{array}$ \\
\hline Formal & $\begin{array}{l}\text { O botão de ajuda na parte superior } \\
\text { direita do palco, mantém-se com o } \\
\text { mesmo padrão na maioria dos objetos }\end{array}$ & $\begin{array}{l}\text { - Não existe um padrão proposto } \\
\text { para o posicionamento dos botões } \\
\text { de navegação; } \\
\text {. Pouca legibilidade dos botões } \\
\text { cancelar, pausa, reiniciar e iniciar; } \\
\text {. Falta de criatividade na construção } \\
\text { de todos os elementos gráficos } \\
\text { propostos }\end{array}$ \\
\hline
\end{tabular}

Fonte: http://rived.proinfo.mec.gov.br

Apesar da preocupação com os padrões dos diversos objetos de aprendizagem, apenas uma pequena parcela utiliza tal padronização (tab.2.3).

Tabela 2.3 - Análise quantitativa da incidência de padronização para os objetos disponíveis no RIVED - Outubro 2006

\begin{tabular}{|c|c|c|c|}
\hline & Padrão RIVED & Fora do Padrão & Total \\
\hline Artes & 4 & 10 & 14 \\
\hline Ciências & 1 & 3 & 4 \\
\hline História & 1 & 4 & 5 \\
\hline Biologia & 4 & 18 & 22 \\
\hline Matemática & 9 & 28 & 37 \\
\hline Física & 4 & 31 & 35 \\
\hline Química & 5 & 23 & 28 \\
\hline Geografia & 0 & 5 & 5 \\
\hline Total geral & 28 & 84 & 117 \\
\hline
\end{tabular}

Fonte: http://rived.proinfo.mec.gov.br/site_objeto_lis.php 
A partir da análise dos pontos negativos e positivos dos elementos gráficos e do HTML propostos pelo RIVED ficou comprovada a necessidade e a possibilidade do re-design desses padrões, uma vez que ainda são pouco utilizados.

Este estudo proporcionou a definição de alguns pré-requisitos para o projeto:

- Otimização do espaço utilizado;

- Acesso a todo conteúdo do módulo na mesma tela;

- Diferenciação das disciplinas por cor;

- Destaque para o material de apoio.

\subsection{Análise das animações}

Para a melhor compreensão das próximas etapas do estudo, considerou-se relevante conceituar a Ergonomia, focalizando a Ergonomia Cognitiva em sistemas informatizados, onde são propostos critérios para a avaliação da usabilidade da interface.

A análise de usabilidade tem como objetivo definir novos pré-requisitos para o projeto.

\subsubsection{Ergonomia, ergonomia cognitiva e sistemas informatizados}

A Ergonomia (ou Fatores Humanos) é uma disciplina científica relacionada ao entendimento das interações entre os seres humanos e outros elementos ou sistemas, e à aplicação de teorias, princípios, dados e métodos a projetos a fim de otimizar o bem estar humano e o desempenho global do sistema. (Associação Internacional de Ergonomia - A.I.E, 2000)

A ergonomia aplicada aos sistemas informatizados busca estudar como ocorre a interação entre os diferentes componentes dos sistemas a fim de elaborar parâmetros a serem inseridos na concepção de aplicativos que orientem os usuários e que contribuam para execução da tarefa, analisando variáveis como a utilidade, a usabilidade do sistema e, especialmente, a dimensão cognitiva envolvida nesse tipo de tarefa.

Analisa também a memória (operativa e longo prazo), e os processos cognitivos implicados na tomada de decisão, na atenção (carga mental e consciência), enfim nas estruturas e nos processos para perceber, armazenar e recuperar informações. O objetivo final da Ergonomia Cognitiva aplicada aos sistemas informatizados é o de compatibilizar as soluções tecnológicas às características e necessidades de seus usuários.

Na relação dos sistemas informatizados/cognição humana, cada novo artefato que aparece na realização da tarefa altera sua natureza, e exige dos usuários competências diferenciadas para a ação. Da mesma forma, novos artefatos são concebidos no intuito de solucionar problemas dos usuários, sendo assim, a 
Ergonomia Cognitiva busca compreender a cognição humana em um contexto de ação e voltada para um objetivo específico (Abrahão; Silvino e Sarmet, 2005).

A Ergonomia Cognitiva torna possível o melhor entendimento sobre quais bases se constroem a competência do usuário e possibilita conceber interfaces informatizadas mais adaptadas. Entende-se por competências as estratégias cognitivas construídas e modificadas pelo indivíduo (Abrahão, Silvino \& Sarmet, 2005).

Com o objetivo de direcionar o esforço cognitivo do usuário específico de um objeto de aprendizagem, para a própria aprendizagem, deve-se assegurar que as competências relacionadas às representações gráficas da interface, uma vez construídas, permaneçam constantes em todos os módulos.

Dessa forma, pode-se inferir a importância da padronização das interfaces digitais, dentro de um mesmo contexto, para a eficiência e eficácia do objeto de aprendizagem, assim como a análise da usabilidade.

\subsubsection{Análise de usabilidade intrínseca - Estudo de casos}

Os critérios de usabilidade visam compreender como se dá a relação do usuário com a interface, levando em conta seu esforço cognitivo, sua experiência e a capacidade de adaptação da interface ao usuário.

A interação do usuário com a interface pode ser facilitada ou dificultada dependendo de como a interface foi concebida. Alguns estudos dentro da ergonomia propõem requisitos a serem analisados para minimizar o esforço cognitivo dos usuários facilitando a chance de sucesso por parte de um usuário ao manipular a interface.

A interface gráfica, além de textos e imagens, engloba uma série de elementos que dificultam ou facilitam a interação usuário/interface.

Nesse estudo foram utilizadas análises quantitativas e qualitativas a fim de obter repostas que serão utilizadas como base para o desenvolvimento durante todo o projeto.

A partir da análise da incidência de padronização para os módulos disponíveis no RIVED (ver tópico 2.3.1) pôde-se identificar claramente três grupos distintos: o primeiro de acordo com o padrão, um segundo com alguma adequação ao padrão e o terceiro totalmente fora do padrão. Para a análise de usabilidade das animações foram escolhidos três objetos sendo um de cada grupo.

\section{Análise qualitativa}

Para ajudar na avaliação durante a análise qualitativa adotou-se os critérios propostos por SCAPIN (1990) e BASTIEN (1991) (tab.2.4). Trata-se de um conjunto de oito critérios principais que se subdividem de modo a minimizar a 
ambigüidade na identificação e classificação das qualidades e problemas ergonômicos do software interativo (SCAPIN; BASTIEN, 1993). Em outras palavras, esses critérios permitem identificar a lógica do funcionamento, dos símbolos e dos elementos familiares em uma interface, consistindo em um "instrumento" fundamental para a evolução do projeto.

Pontuaram-se aspectos positivos e negativos dos três módulos/atividades do RIVED com base nos critérios propostos por SCAPIN e BASTIEN. Abaixo descreve elementos de maior destaque encontrado nas análises.

O primeiro ponto importante notado em compatibilidade foi à utilização da tecnologia Flash (Adobe Systems Incorporated) em todos os módulos que existem no sítio do RIVED. O ponto positivo é que a maioria dos computadores com acesso a internet possuem o FlashPlayer, responsável para rodar os arquivos do flash (extensões SWF). Porém não existe nenhum botão para pessoas que tenham uma versão mais antiga, ou ainda não possua, possa baixar e instalar o plugin em sua máquina.

Tabela 2.4 - Critérios Ergonômicos de Usabilidade - Scapin e Bastien - 1993

\begin{tabular}{|c|c|}
\hline \multirow{4}{*}{ A Condução } & - Presteza \\
\hline & - Feedback Imediato \\
\hline & - Legibilidade \\
\hline & - Agrupamento/Distinção de Itens \\
\hline \multirow{2}{*}{ A Carga de Trabalho } & - Brevidade \\
\hline & - Densidade Informacional \\
\hline \multirow[b]{2}{*}{ O Controle Explícito } & - Ações Explícitas do Usuário \\
\hline & - Controle do Usuário \\
\hline \multirow{2}{*}{ A Adaptabilidade } & - Flexibilidade \\
\hline & - Consideração da experiência do usuário \\
\hline \multirow{3}{*}{ A Gestão de Erros } & - Proteção contra os erros \\
\hline & - Qualidade das mensagens de erro \\
\hline & - Correção dos erros \\
\hline
\end{tabular}

A Homogeneidade/Coerência

O Significado dos Códigos e Denominações

A Compatibilidade

Nota: Traduzido por Walter Cybis 
O acesso aos módulos, através janelas popups (janelas do navegador, geralmente de tamanho reduzido, usadas para complementar o conteúdo do sítio) dificultam o acesso, já que muitos navegadores possuem recursos de anti-popup instalados.

O público alvo das aulas, de acordo com os dados retirados do próprio sítio e por funcionários do RIVED, são alunos do ensino médio, porém a estética empregada não condiz com a faixa etária (14 aos 18 anos).

Os botões de navegação entre as telas, talvez por não serem padronizados em todos os módulos, contribuam negativamente com a navegação em vários aspectos. Não é considerada a experiência do usuário desde aspectos gráficos a posicionamento em tela. Muitos usuários, com certa experiência na utilização de computadores, acostumaram-se com a utilização do botão " $X$ " para encerrar um aplicativo ou janela, porém em alguns módulos este botão estava sendo utilizado para retornar uma tela, ou avançar a atividade.

As interfaces mostram-se pouco prestativas em alguns aspectos. Foram observados casos, em que, para continuar a atividade era necessário "clicar" em algum item da tela, porém, esses itens não estavam devidamente destacados dos outros elementos na tela, fazendo com que o usuário procurasse áreas ativas (clicáveis) passando o mouse sobre elas. Essa "busca por informações" poderá ser cansativa e fazer com que o usuário não explore todo conteúdo da atividade.

A concisão demonstrada pelo conteúdo favorece seu entendimento, devido a baixa carga de informações, otimizando o esforço cognitivo do usuário.

Outro ponto observado foi quanto a gestão de erros. Não existem informações de que, ao entrar em uma atividade, o arquivo referente esteja sendo carregado, e em muitos casos o arquivo após carregado não era exibido, tornando necessária a atualização da janela do navegador para a correta visualização.

\section{Análise quantitativa}

Observando os objetos já existentes no RIVED, notou-se a existência de três grandes grupos de objetos que foram evoluindo ao longo do tempo ou não, em termos de estética, padronização, arquitetura de informações entre outros.

O primeiro grupo não seguia nenhum padrão, seja por falta desde ou por escolha de uma concepção totalmente nova no seu projeto (fig.2.10). 


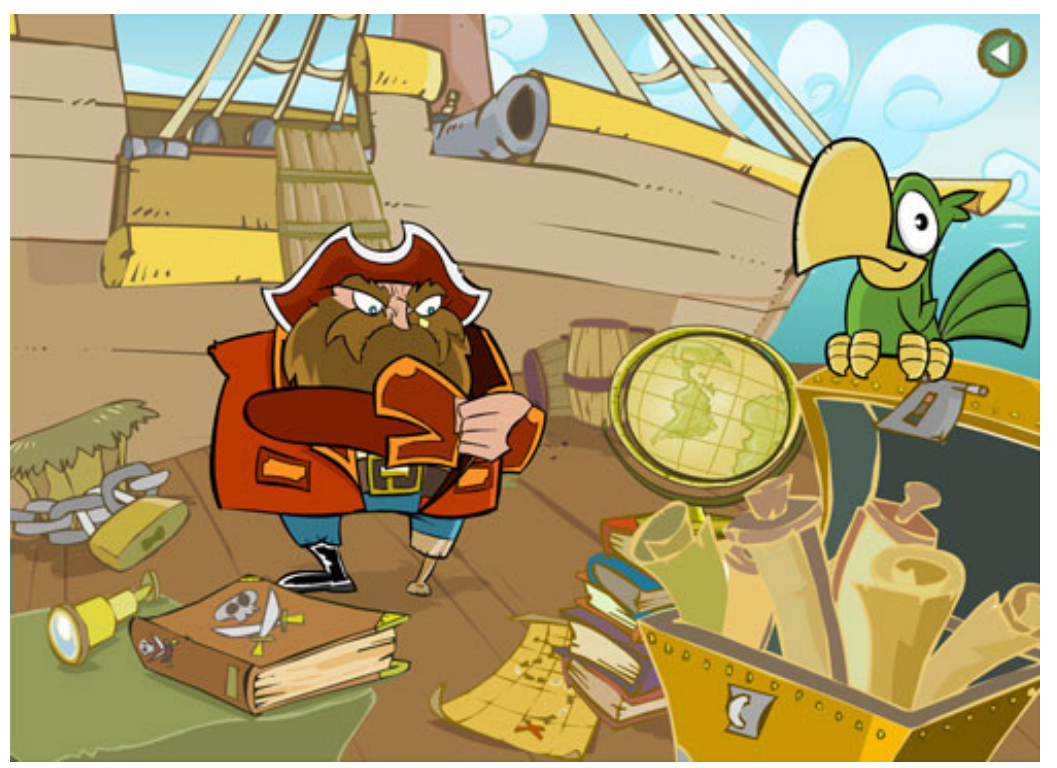

Figura 2.10 - Módulo Analisado - Grupo I

Fonte: http://rived.proinfo.mec.gov.br, out 2006

O segundo grupo pode se notar indícios da utilização e tentativa de se adaptar aos padrões propostos pelo RIVED (fig.2.11).

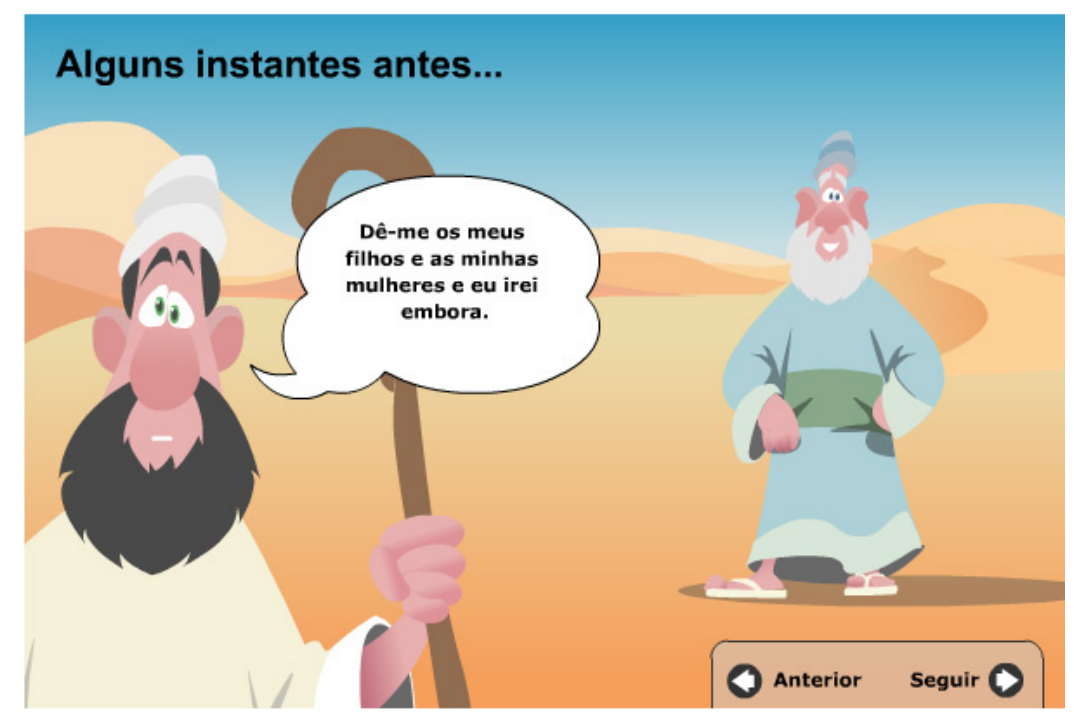

Figura 2.11 - Módulo Analisado - Grupo II

Fonte: http://rived.proinfo.mec.gov.br, out 2006

O último grupo tenta seguir rigidamente todos os padrões propostos (fig.2.12). 


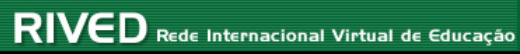

Atividade "Quão Grande é?"
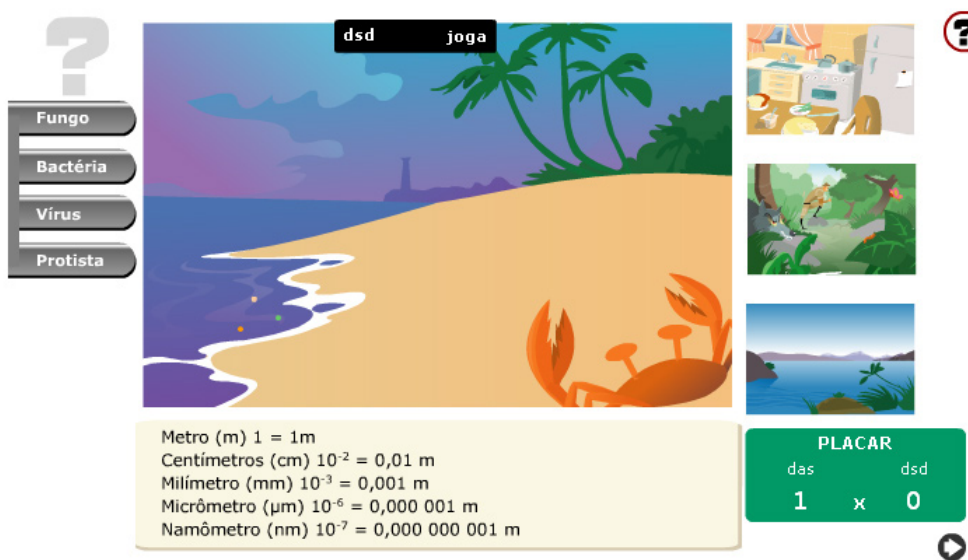

RIVED

Figura 2.12 - Módulo Analisado - Grupo III

Fonte: http://rived.proinfo.mec.gov.br, out 2006

Com posse dessas informações decidiu-se pegar 3 objetos, 1 de cada grupo, e fazer uma análise quantitativa através de critérios que foram criados a fim de obter o máximo de informações (estéticas e funcionais) de cada grupo, para os elementos dispersos pelo módulo (tab.2.5).

A intenção principal desta análise não é pontuar pontos negativos ou positivos, mas sim, conhecer melhor os módulos de ensino.

Tabela 2.5 - Representação por números dos elementos dispersos pelos módulos de ensino

\begin{tabular}{|c|c|c|c|}
\hline Critérios & Modulo 1 - GEO & Modulo 2 - BIO & Modulo 3 - BIO \\
\hline Telas/Cenários & 10 & 14 & 6 \\
\hline Atividades & 1 & 5 & 1 \\
\hline Link/Botões & 10 & 3 & 3 \\
\hline Padrão cromático & Colorido & Colorido & Colorido \\
\hline Fontes & 2 & 1 & 2 \\
\hline Cores nas fontes & 6 & 3 & 2 \\
\hline Personagens & 2 & 2 & 4 \\
\hline Possui áudio & SIM & NÃO & SIM \\
\hline Desenhos & Animado & Estatico & Animado \\
\hline Questões & 2 & 1 & 1 \\
\hline
\end{tabular}

A análise de usabilidade propiciou a definição de novos pré-requisitos discriminados abaixo:

- Destaque ao botão ajuda;

- Contraste de cores, objeto/fundo; 
- Padronização dos botões recorrentes;

- Informação para facilitar a localização do usuário;

- Direcionar a atenção ao objeto de aprendizagem (animação);

- Destaque ao conteúdo da atividade.

\section{Botões de navegação - análise quantitativa}

Foram analisados dez objetos aleatoriamente com o objetivo de mensurar a recorrência dos botões de navegação das animações.

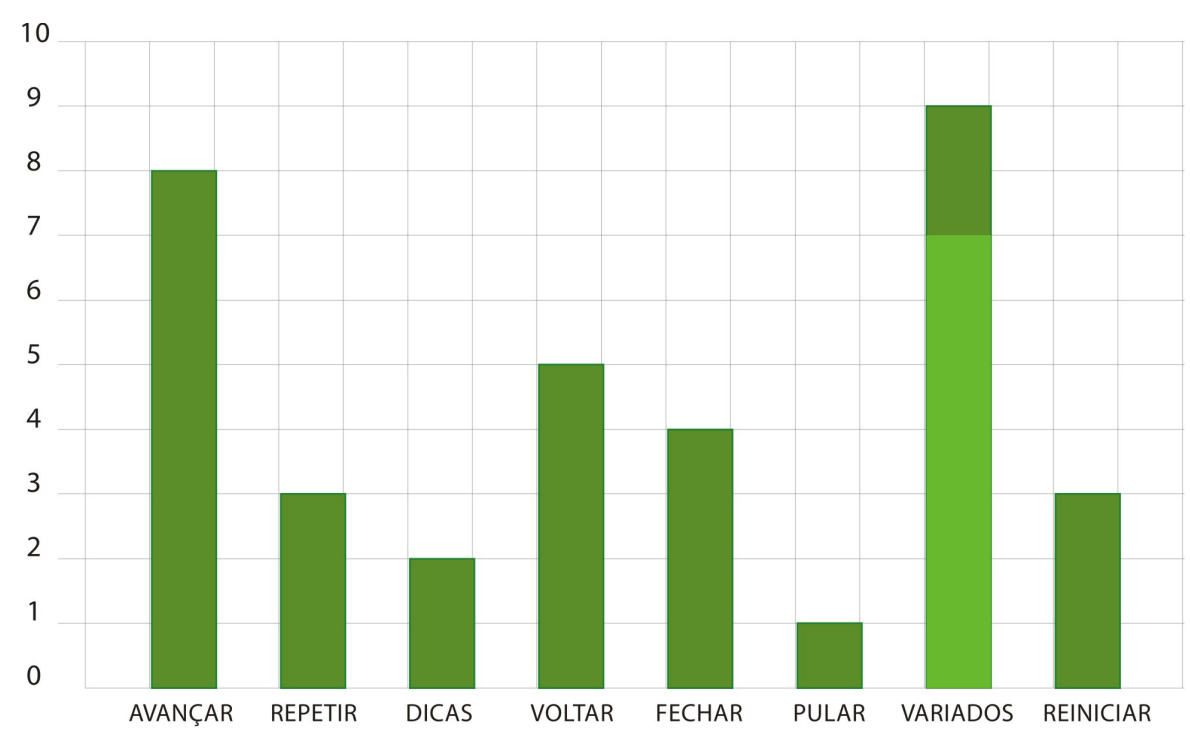

Média de 3,6 botões por atividade

Figura 2.13 - Gráfico de ocorrência de botões para navegação - outubro 2006 Fonte: http://rived.proinfo.mec.gov.br/site_objeto_lis.php

Os botões que tiveram a maior ocorrência foram os de avançar a tela atual (8 vezes) e voltar para tela anterior (5 vezes). Os botões "variados", para não ser chamados de "outros", são todos os botões que não tiveram repetição entre um módulo e outro, o que sugere uma necessidade de um botão personalizável para ser utilizado em diversas ocasiões.

Apesar dos botões "repetir" e "reiniciar" estarem representados separadamente no gráfico (fig.2.13), em muitos casos eles possuíam uma função similar: "levar o usuário para a primeira dela do objeto de ensino".

\section{Estudo de botões similares}

Foi realizada uma pesquisa sobre os tipos de botões mais comumente usados, com o objetivo de conceber botões de navegação das animações do RIVED mais familiares ao usuário (fig.2.14). 

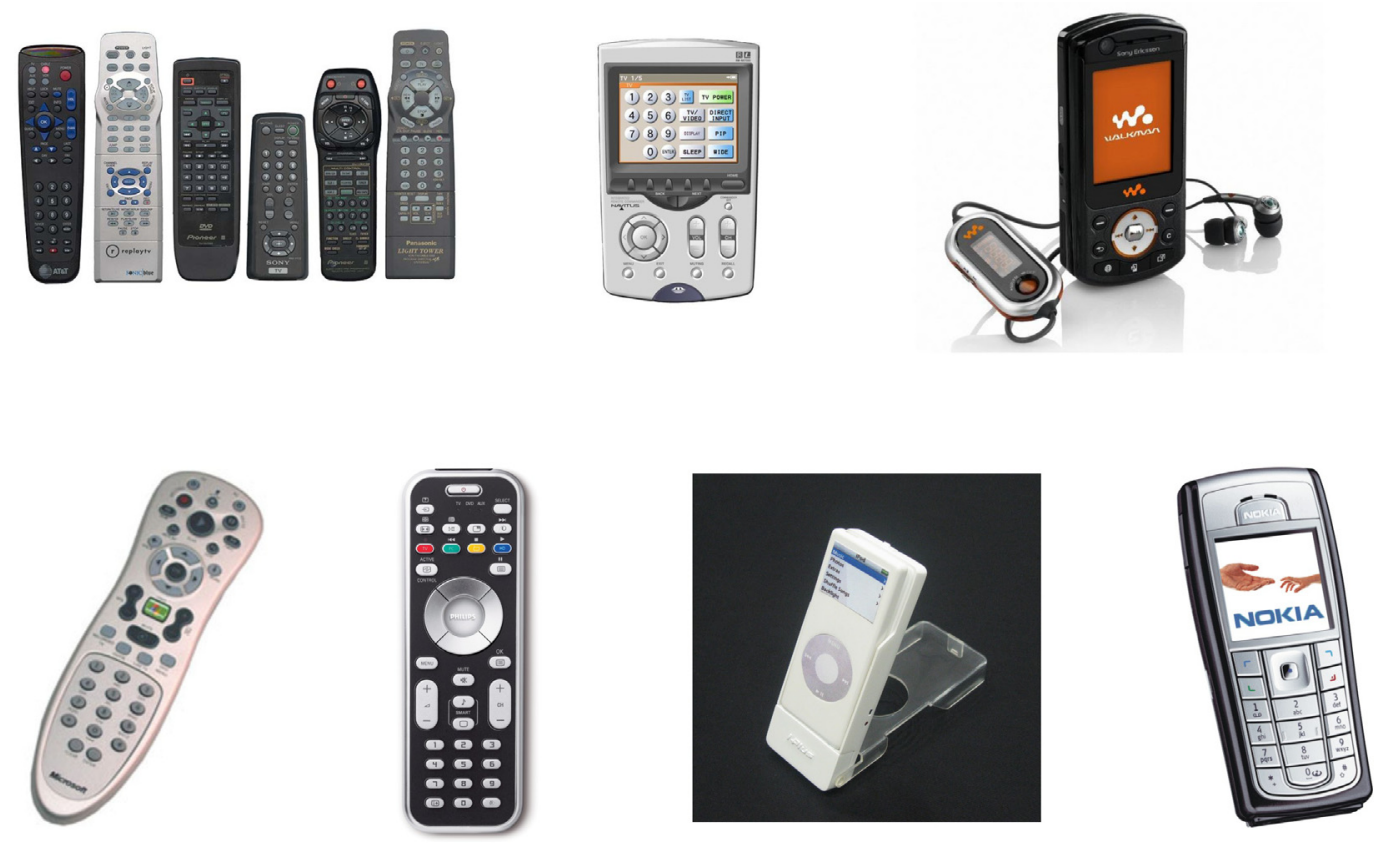

Figura 2.14 - Botões para navegação - estudo de similares

Os botões encontrados são de controles de eletrodomésticos como televisores, vídeos-cacetes, DVDs entre outros. Outro objeto importante de uso freqüente pelos usuários são os celulares.

A disposição dos botões está padronizada linearmente, seja verticalmente ou horizontalmente. Há uma utilização excessiva da forma geométrica, sendo a forma circular a mais predominante. Os botões que tem função de alterar níveis como, mudar de canal, aumentar o volume, avançar nas opções do menu do celular são representados por figuras gráficas como setas e/ou formas triangulares. A cores são usadas de forma moderada com preferência de cores neutras como branco, cinza ou preto.

Existe uma harmonia entre a forma dos objetos (circulares com quinas arredondadas) e a composição dos botões.

\subsection{O design gráfico como facilitador do aprendizado}

A atividade do designer é um serviço prestado a clientes de diferentes áreas e, portanto, não pode ser considerada uma prática desvinculada de outros interesses. Além disso, associa-se ao compromisso de comunicar ou visa obter determinadas respostas e efeitos do público a que se dirige. Entretanto, ao buscar certas reações de sua audiência, o designer tem a possibilidade de usar diferentes recursos e estratégias, transitando por uma infinidade de possibilidades de articulação das mensagens em seus aspectos visuais e é no exame dos vários elementos envolvidos no processo de design (cliente, intenção comunicativa, público-alvo, recursos disponíveis, etc) que é possível avaliar qual a 
opção mais adequada para desenvolver determinado projeto.

A escolha da tipografia, as cores utilizadas, a distribuição e o equilíbrio dos elementos e os signos empregados visam à harmonia do projeto gráfico e ao mesmo tempo, proporcionam uma comunicação eficiente e agradável.

Ainformática, ao ser introduzida como ferramenta de design, causou um momento inicial de certa padronização nos layouts, assentada na utilização desmedida dos recursos de vários softwares. A alteração técnica, disseminada rapidamente pelos computadores domésticos, fascinou pela facilidade com que uma ampla variedade de recursos gráficos tornou-se disponível ao usuário comum. Um universo técnico, que exigia formação profissional, abriu um campo de atuação para pessoas sem conhecimentos específicos ou educação estética adequada. De certo modo, essa noção mágica, fetichista, da execução fácil, criou a ilusão de que qualquer um seria capaz de desenvolver uma boa peça gráfica sem esforço e com rapidez.

No caso em estudo, os objetos de aprendizagem disponíveis no RIVED, em sua grande maioria, foram elaborados com ênfase no design instrucional com a colaboração de programadores, professores e outros profissionais, não contando com a presença de designers, deixando em segundo plano o projeto de programação visual.

O design da educação, em muitos casos, preocupado em garantir a clareza e legibilidade das informações utiliza-se de um formalismo objetivo e funcional, ou ainda, utiliza imagens para ilustrar o conteúdo objetivo entrando em redundância com o texto, e despreza um imenso potencial estético, simbólico e semântico que também Ihe caberia explorar, afim de favorecer o aprendizado.

Evidentemente, não é possível abranger a totalidade das influências envolvidas nos processos de desenvolvimento cognitivo com um projeto de design, no entanto isto é mais provável com a colaboração interdisciplinar na concepção de objetos de aprendizagem.

Os projetos de interfaces para a educação podem promover maior interação, novas formas de conhecimento, e uma qualificação da comunicação explorando, também, o potencial estético.

Para que uma imagem promova uma experiência estética não basta que seja vista. É necessário que em sua forma tenha conteúdo capaz de promover um corte na experiência banal, que, mesmo efêmero, re-signifique a existência, mas isso não garante que a experiência ocorra, ou que ocorra igualmente com todos. Estabelecer uma relação específica com o espectador, provocando o olhar e captando sua atenção depende também desse olhar, do contexto, da cultura, da história, da subjetividade individual. (KRUSSER; GEREMIAS, 2004) 
Dessa forma, para se alcançar um resultado eficiente e eficaz de um objeto de aprendizado é necessário o trabalho conjunto dos profissionais de educação, designer pedagógico, usabilidade (do ponto de vista da ergonomia cognitiva) e dos padrões estéticos e atrativos, do ponto de vista da comunicação, propostos pelos designers.

Além disso, o contexto econômico, cultural, social e a faixa etária dos usuários são elementos relevantes na adequação da linguagem adotada, portanto devem ser levados em conta na elaboração deste projeto.

\subsection{O usuário}

Os usuários dos objetos de aprendizagem disponíveis na página do RIVED são: os professores e principalmente os alunos do ensino médio da rede pública, com idade entre 14 a 18 anos.

\subsubsection{Paineis de estilo}

Os produtos devem ser projetados para transmitir certos sentimentos e emoções. Isso deve ser conseguido construindo-se diversos painéis de imagens visuais. Através desses painéis podem-se retirar requisitos extremamente importantes para o andamento do projeto.

\section{Estilo para educação}

O ambiente escolar caracteriza-se por ser austero e disciplinador, onde a comunicação normalmente ocorre de forma unidirecional, ou seja, o professor é o detentor do conhecimento, o comunicador, o aluno é o receptor, que deve pedir autorização para se expressar. A individualidade, posta em segundo plano, é percebida pela utilização do uniforme escolar, padronização do mobiliário e materiais. As formas geométricas, as cores de baixo contraste e a falta de estímulos sensoriais externos, ajuda a direcionar a atenção dos alunos para o educador. 


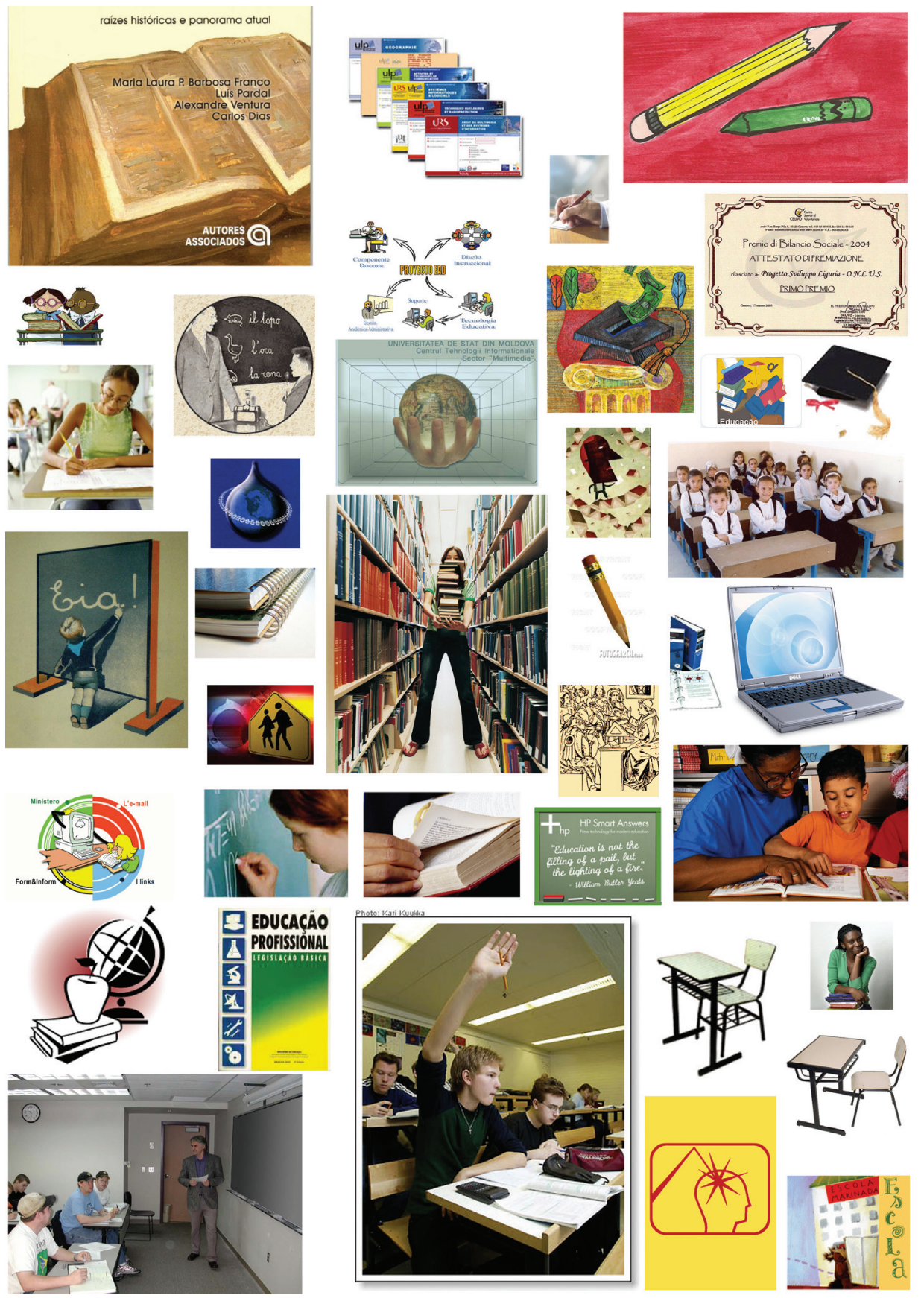

Figura 2.15 - Painel de estilo ambientes educacionais

\section{Estilo dos estudantes}

Clara possibilidade de comunicação e expressão - piercings, tatuagens, celulares e principalmente a internet - são formas de destacar a individualidade. Personalização e interação são palavras cada vez mais presentes na escolha de produtos. As cores, as formas, os grafismos, os sons são modificados de acordo com a personalidade de cada indivíduo. Os padrões criados, envolvendo formas orgânicas, remetem à liberdade, ao despojamento, ao movimento e à fluidez. Porém, apesar dessas características, continuam sendo padrões impostos pelo modismo, uma vez que se percebe a reincidência dos elementos estéticos de comunicação. 


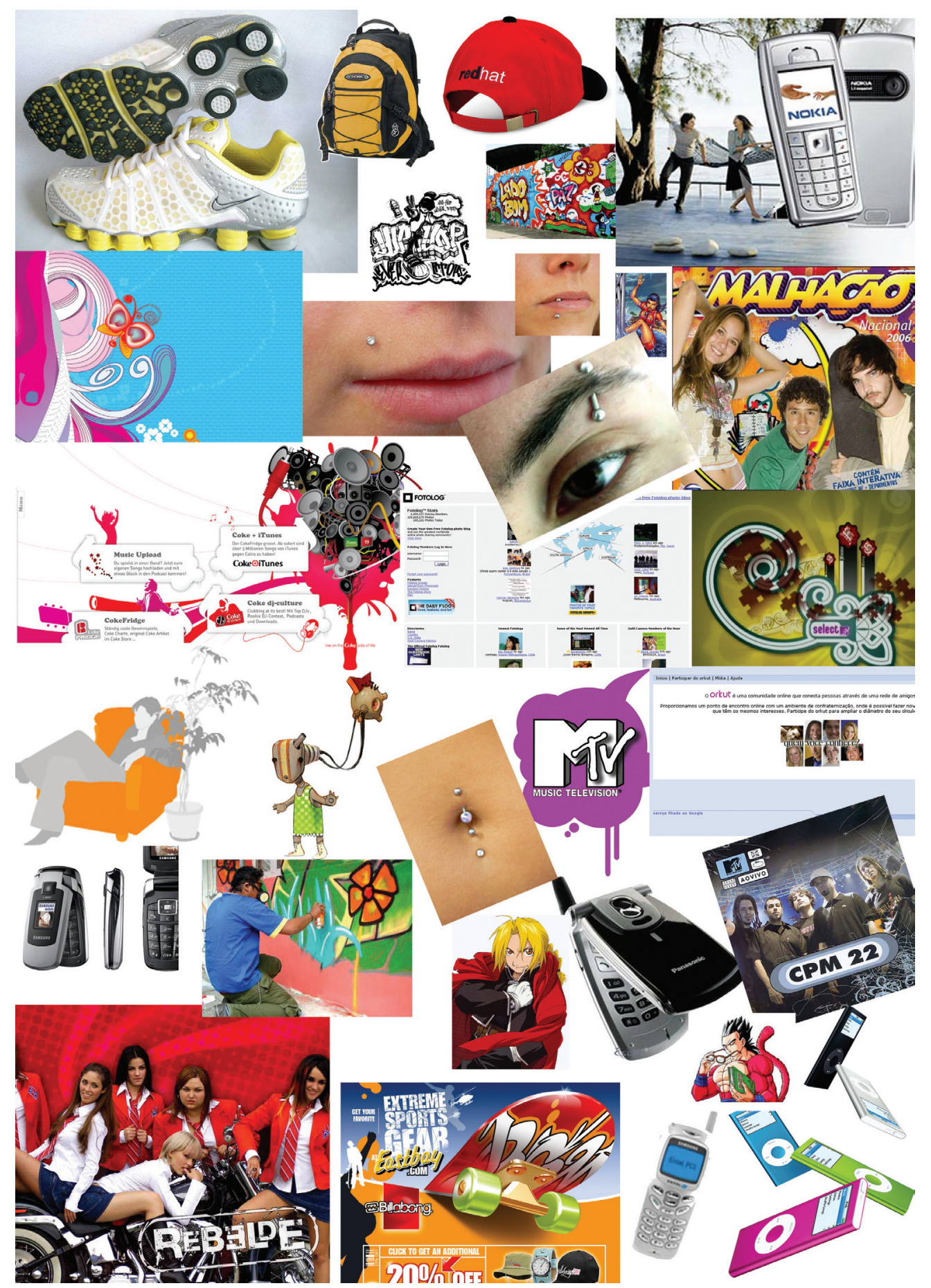

Figura 2.16 - Painel de estilo estudantes

\section{Análise dos estilos}

Os dois painéis são extremamente contrastantes. Para o objeto educacional em questão é importante a observação cuidadosa das tendências do estilo de vida do usuário. O objetivo deste projeto é tornar a experiência de aprendizagem lúdica, despertando o interesse do aluno espontaneamente, sem a rigidez observada no método de ensino convencional.

Essa análise permitiu conhecer melhor o usuário, seu estilo de vida, seu contexto social e o ambiente de ensino, possibilitando a enumeração dos seguintes pré- 
requisitos para o projeto:

- Variações tonais de uma matiz

- Cores chapadas

- Formas orgânicas e ornamentadas (ondulações e fluidez)

- Tipografia com um grande peso de linha

- Ausência de linhas de contorno

- Padrões de texturas geométricas

- Remeter à educação

- Remeter à informática 


\section{Definição do problema}

\subsection{Lista de pré-requisitos para a elaboração do projeto}

Após todas as análises, foram listados alguns itens que deverão ter relevância para o projeto, a fim de sanar alguns problemas apontados.

Os requisitos foram distribuídos em três grupos de prioridade:

Grupo1: Obrigatoriamente presente no projeto.

- Otimização do espaço utilizado

- Diferenciação das disciplinas por cor

- Direcionar a atenção ao objeto de aprendizagem (animação)

- Destaque ao material de apoio

- Destaque ao conteúdo da atividade

- Padronização dos botões recorrentes

- Informação para facilitar a localização do usuário

- Destaque ao botão ajuda

Grupo2: Desejável que esteja presente no projeto.

- Contraste de cores, objeto/fundo

- Variações tonais de uma matiz

- Formas orgânicas e ornamentadas (ondulações e fluidez)

- Acesso a todo conteúdo do módulo na mesma tela (sem rolagem)

- Remeter à educação

- Remeter à informática

Grupo 3: Podem estar no projeto.

- Cores chapadas

- Ausência de linhas de contorno

- Padrões de textura geométricos

- Tipografia com um grande peso de linha 


\section{Geração de alternativas}

Tendo como base na lista de pré-requisitos iniciou-se a geração das alternativas.

Para o padrão HTML proposto buscou-se, desde o início, um apelo estético que se aproximasse do usuário, porém sem concorrer visualmente com as animações (foco do programa RIVED).

Foram propostas duas animações, uma na área de Artes outra na área de Física.

$\mathrm{Na}$ área de Artes o conteúdo diz respeito à escala musical pitagórica, tendo como personagem central a figura de Pitágoras.

O conteúdo relativo a Física trata-se dos conceitos de inércia, cujos personagens são Aristóteles, Galileu e Newton.

Por se tratar de personagens reais de épocas e ambientes diferentes, a geração de alternativas envolveu pesquisa histórica na tentativa de chegar a uma concepção fiel. As descrições físicas dos personagens também fizeram parte deste estudo.

\subsection{Alternativas para o padrão HTML}

A área para o HTML foi definida em $770 \times 445$ pixels, por se adequar à visualização em monitores com resolução $800 \times 600$ pixels, ainda muito utilizados.

Uma vez definida a área iniciou-se a busca por elementos estéticos semânticos e funcionais adequados aos requisitos do projeto.

Foram, também, definidas cores para diferenciação de cada uma das disciplinas (fig.3.1). 
-Exatas

Cores Frias:

Física

$0,127,255$

Matemática 163, 0, 255

Química $\quad 0,255,255$

Biologia $\quad 0,255,127$

-Humanas

Cores Quentes:

Artes 255, 163, 0

Geografia 255, 0, 63

Historia $\quad 255,0,255$

Figura 4.1 - Cores Padrões para diciplinas

\subsection{1 llustrações}

Primeiramente foram desenvolvidas ilustrações, com a intenção de criar um padrão estético condizente com a realidade dos estudantes remetendo ainda à educação e à informática.

A idéia inicial (fig.4.2; fig.4.3) consistiu em utilizar uma analogia entre o elemento "lápis" e a educação, combinada com formas orgânicas e ornamentos conforme o painel de estilo do usuário. A marca RIVED permanece inalterada.

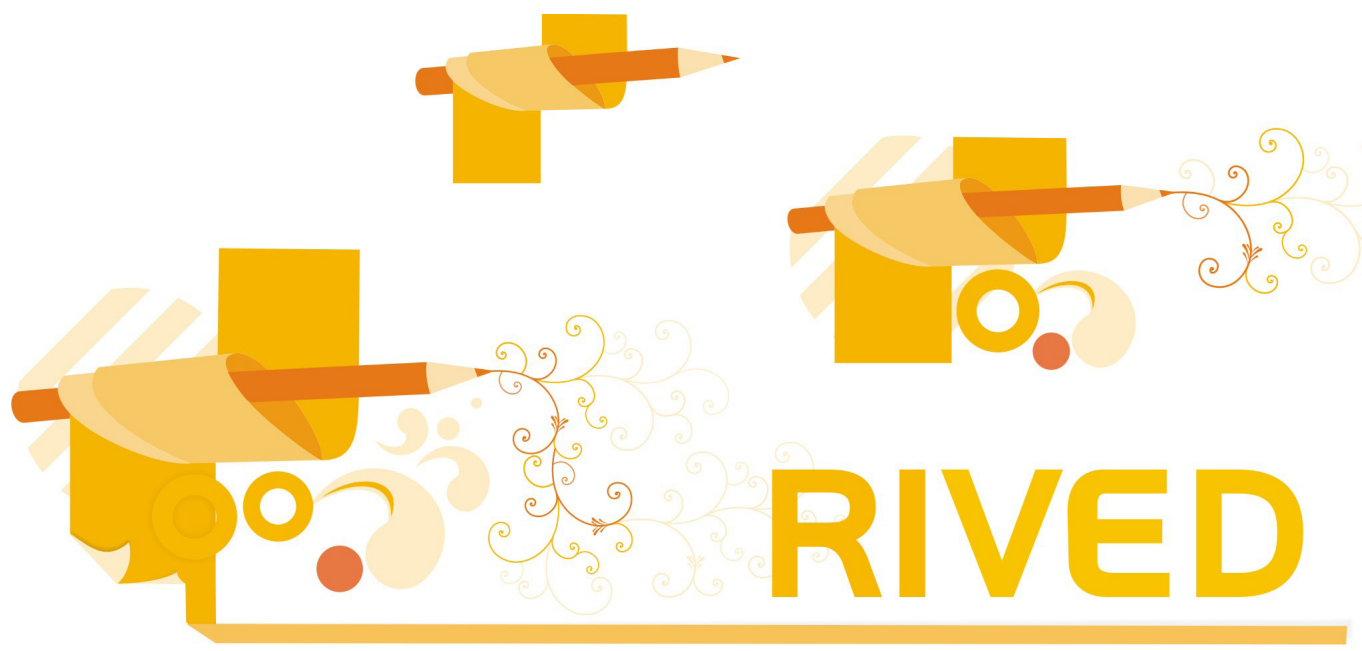

Figura 4.2 - Lápis e fita 

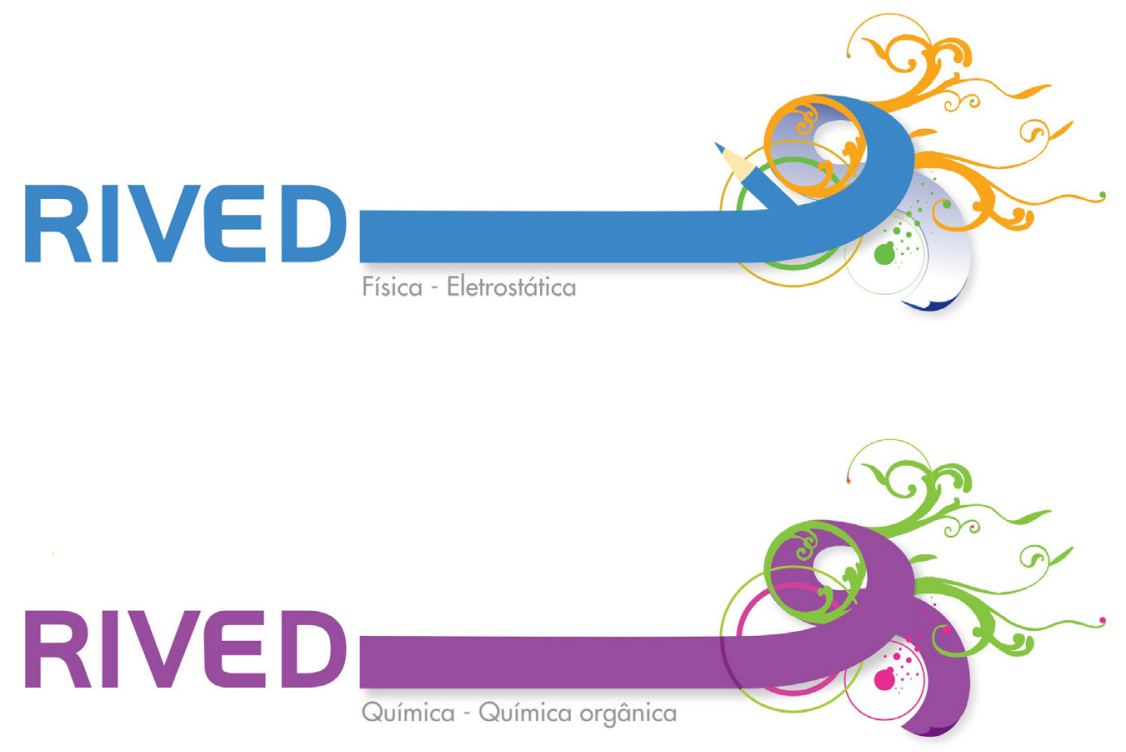

Figura 4.3 - Lápis e fita

Em uma segunda alternativa (fig.4.4) foi inserido o mouse como analogia à informática , e mantido o elemento "lápis", porém não foram utilizadas as formas orgânicas. A gota de tinta foi utilizada, somente, como elemento de equilíbrio do peso visual da composição.

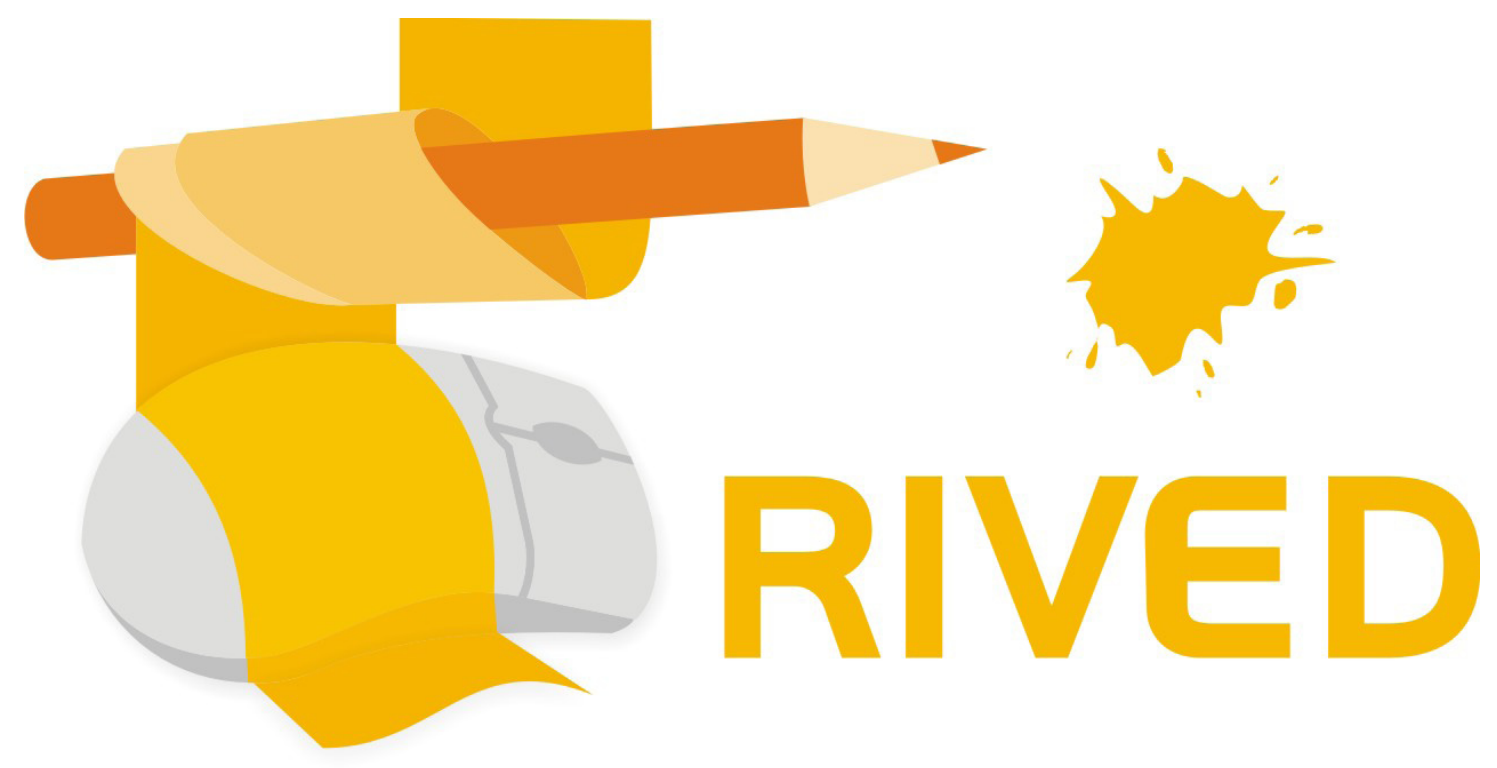

Figura 4.4 - Mouse e lápis

Ainda utilizando o conceito do mouse, alguns ícones (fig.4.5) foram criados, porém não se adequaram aos requisitos relativos ao usuário e à otimização do espaço utilizado. 

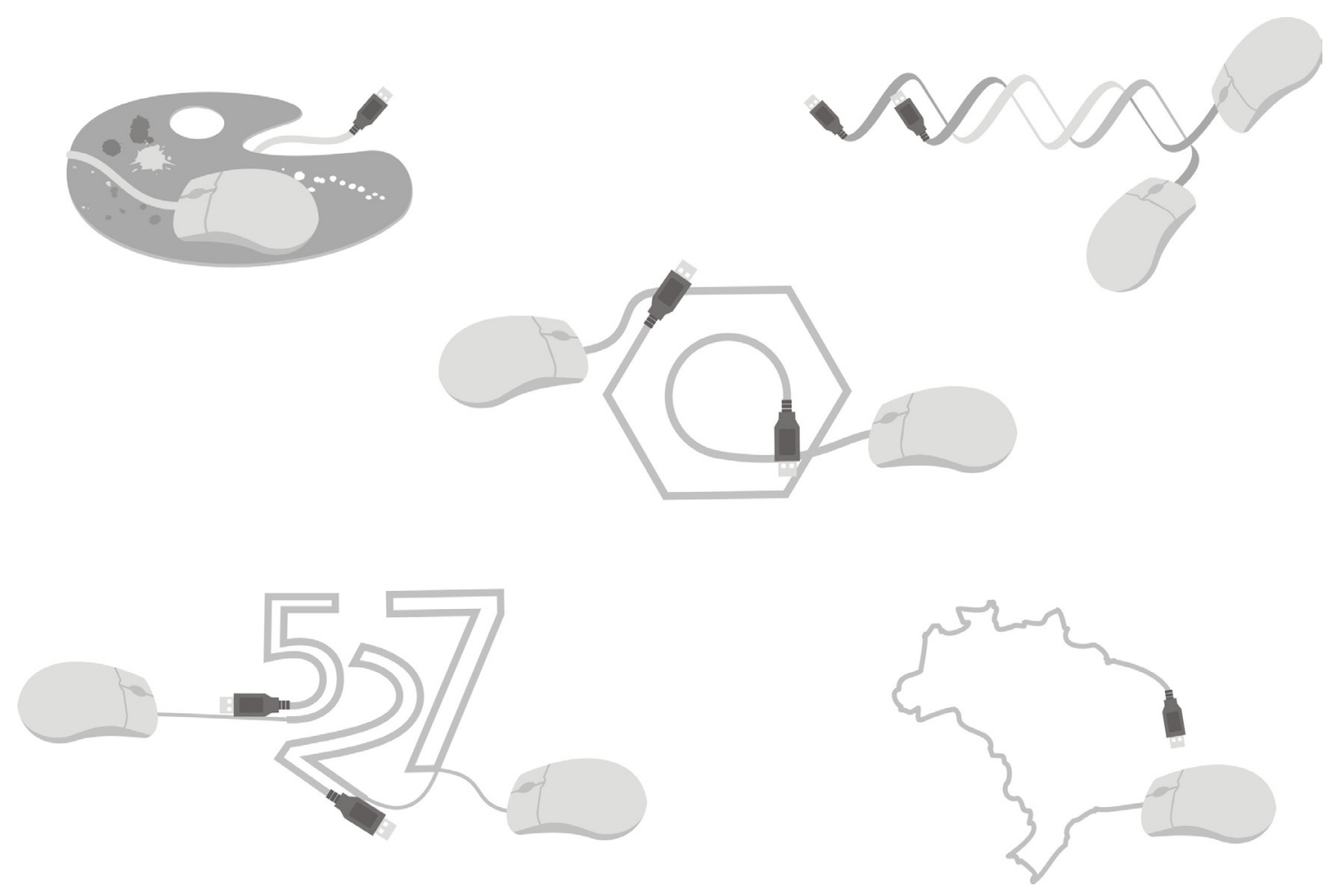

Figura 4.5 - Ícones

A ilustração da figura 4.6, engloba os conceitos educação (lápis) informática (plug USB) e está de acordo com o estilo do usuário (formas orgânicas e ornamentadas, cores chapadas, variação tonal de uma mesma matiz e ausência de linha de contorno).

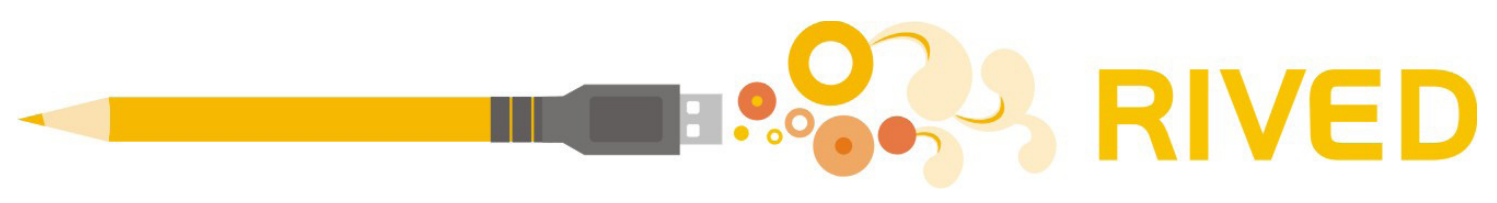

Figura 4.6 - Lápis USB

\subsubsection{Aplicações no formato padrão}

Para a avaliação das alternativas geradas foram criadas tabelas a fim de verificar se os pré-requisitos foram cumpridos ou não. A diferenciação por cores indica a qual grupo de prioridade pertence o pré-requisito:

Grupo1: Obrigatoriamente presente no projeto (verde).

Grupo2: Desejável que esteja presente no projeto (amarelo).

Grupo 3: Podem estar no projeto (vermelho)

Esse método de avaliação foi aplicado em doze propostas de layout. 


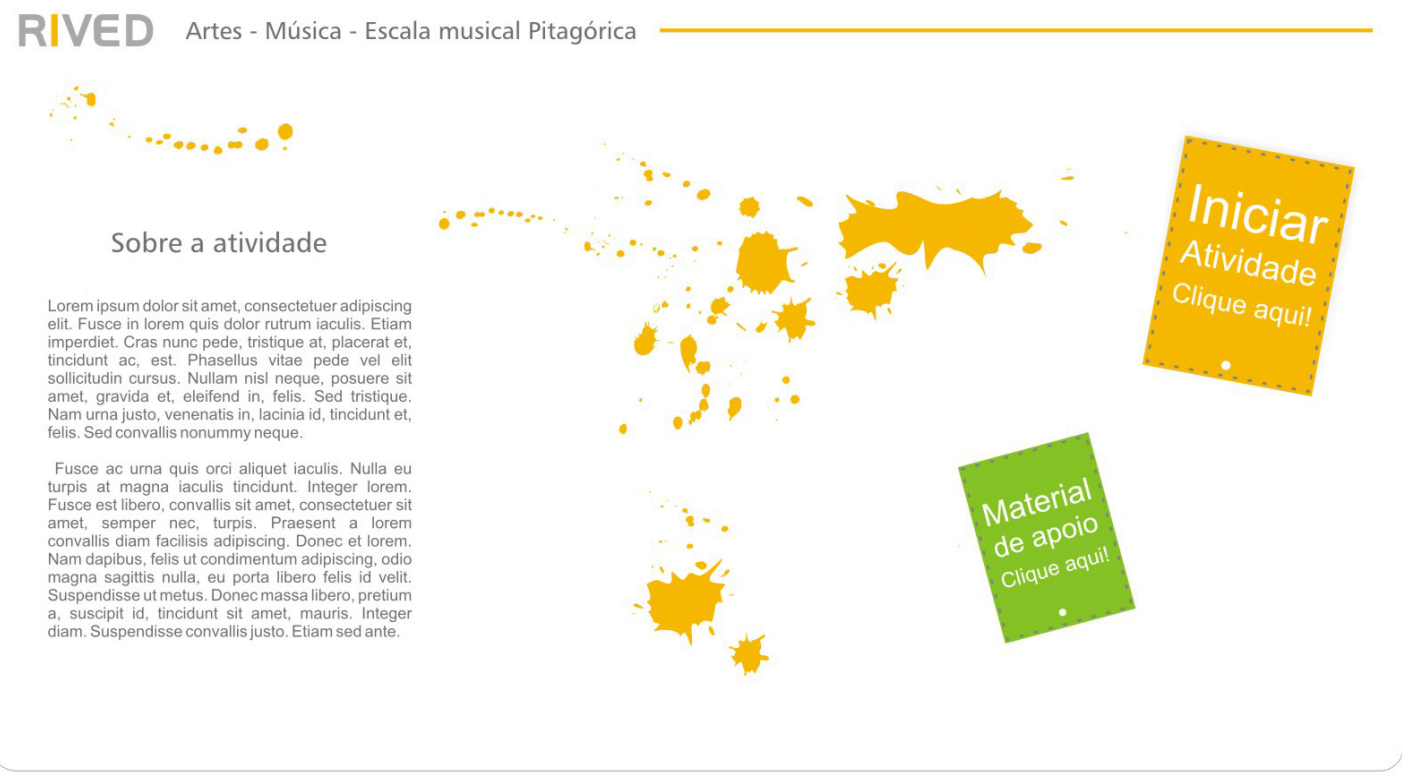

\begin{tabular}{|l|l|l|}
\hline & SIM & NÃO \\
\hline Informação para facilitar a localização do usuário & & \\
\hline Otimização do espaço utilizado & & \\
\hline Diferenciação das disciplinas por cor & & \\
\hline Direcionar a atenção ao objeto de aprendizagem (animação) & & \\
\hline Destaque ao botão ajuda & & \\
\hline Destaque ao material de apoio & \\
\hline Destaque ao conteúdo da atividade & \\
\hline Padronização dos botões recorrentes & \\
\hline Remeter à educação & \\
\hline Remeter à informática & \\
\hline Acesso a todo conteúdo do módulo na mesma tela (sem rolagem) & \\
\hline Formas orgânicas e ornamentadas (ondulações e fluidez) & \\
\hline Contraste de cores, objeto/fundo & \\
\hline Variações tonais de uma matiz & \\
\hline Cores chapadas & \\
\hline Tipografia com um grande peso de linha & \\
\hline Padrões de textura geométricos & \\
\hline Ausência de linhas de contorno & \\
\hline
\end{tabular}

Figura 4.7 - Proposta 1 


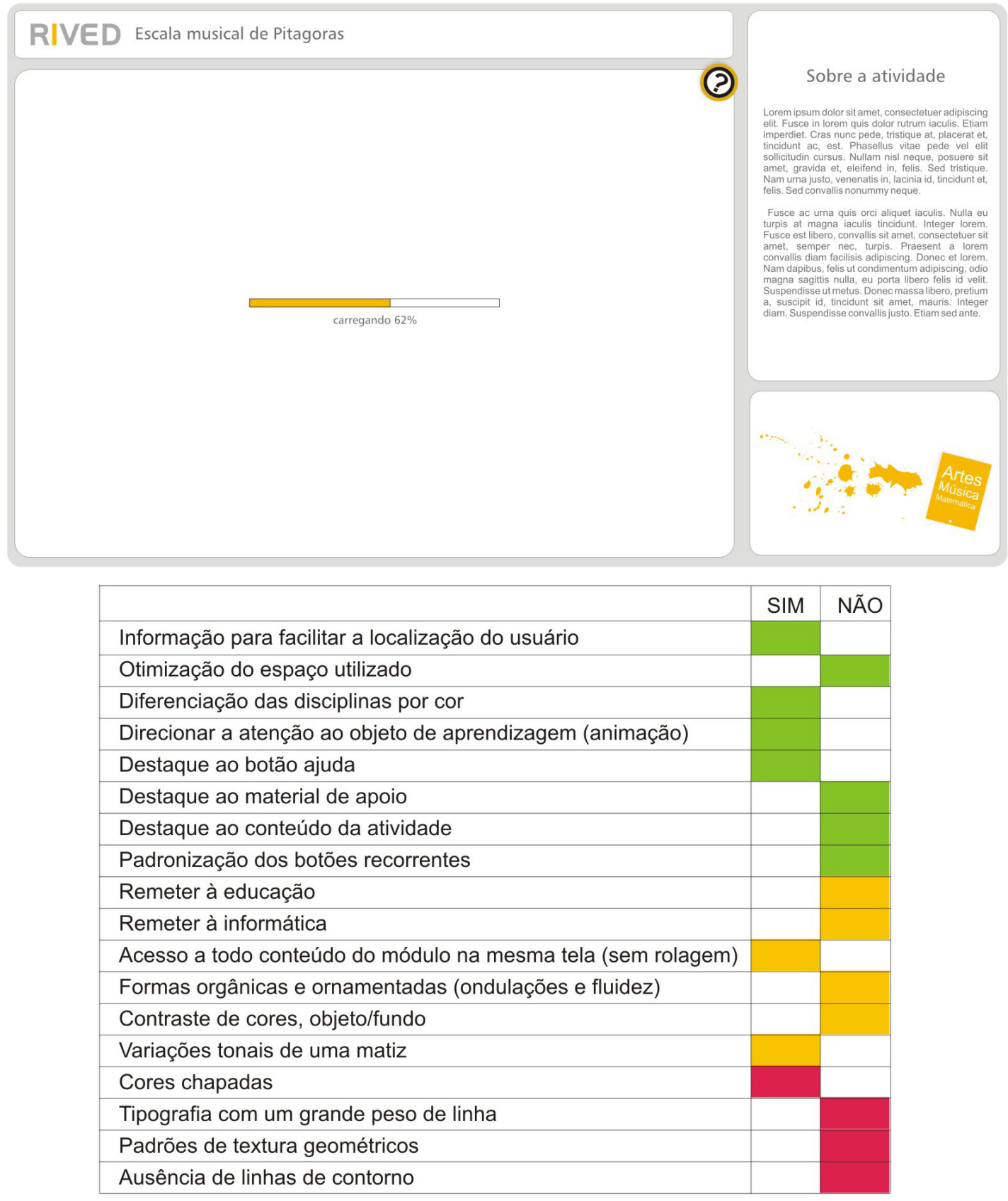

Figura 4.8 - Proposta 2 


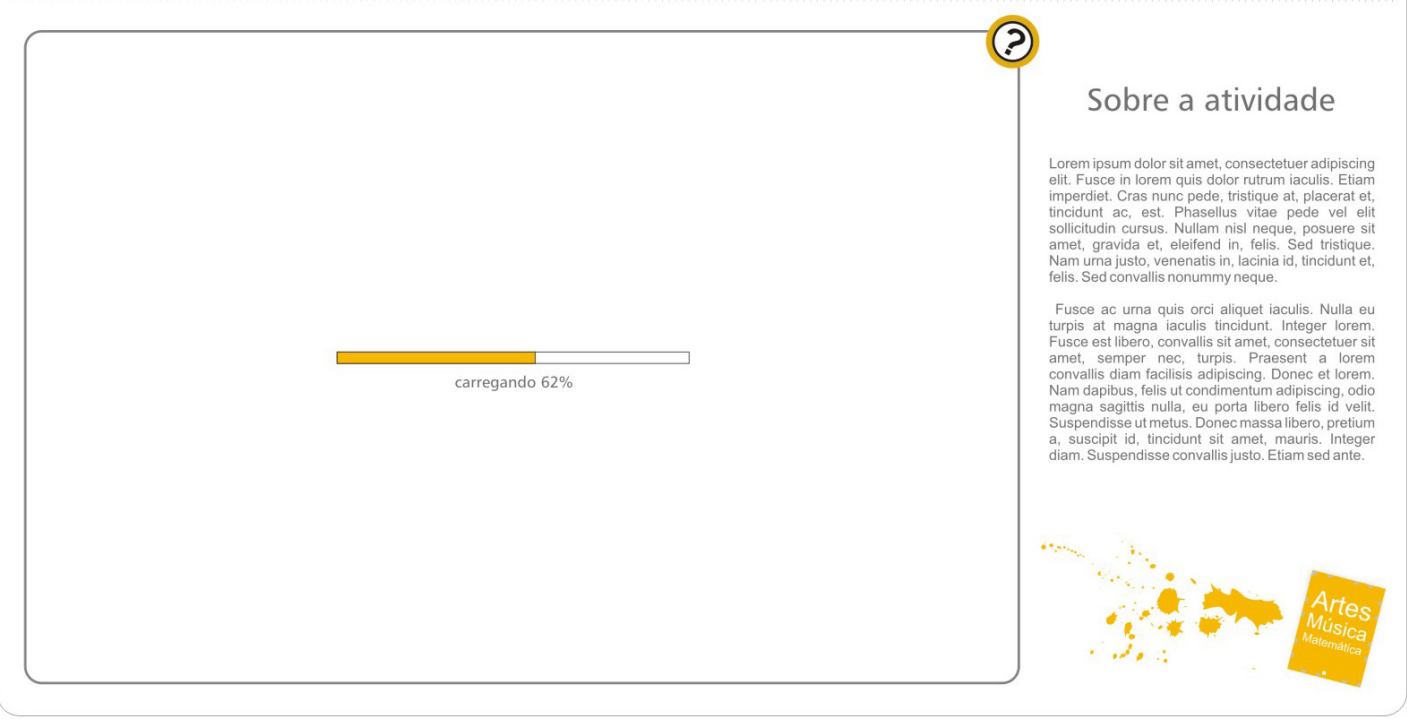

\begin{tabular}{|l|l|l|}
\hline & SIM & NÃO \\
\hline Informação para facilitar a localização do usuário & & \\
\hline Otimização do espaço utilizado & \\
\hline Diferenciação das disciplinas por cor & \\
\hline Direcionar a atenção ao objeto de aprendizagem (animação) & \\
\hline Destaque ao botão ajuda & \\
\hline Destaque ao material de apoio & \\
\hline Destaque ao conteúdo da atividade & \\
\hline Padronização dos botões recorrentes & \\
\hline Remeter à educação & \\
\hline Remeter à informática & \\
\hline Acesso a todo conteúdo do módulo na mesma tela (sem rolagem) & \\
\hline Formas orgânicas e ornamentadas (ondulações e fluidez) & \\
\hline Contraste de cores, objeto/fundo & \\
\hline Variações tonais de uma matiz & \\
\hline Cores chapadas & \\
\hline Tipografia com um grande peso de linha & \\
\hline Padrões de textura geométricos & \\
\hline Ausência de linhas de contorno & \\
\hline
\end{tabular}

Figura 4.9 - Proposta 3 


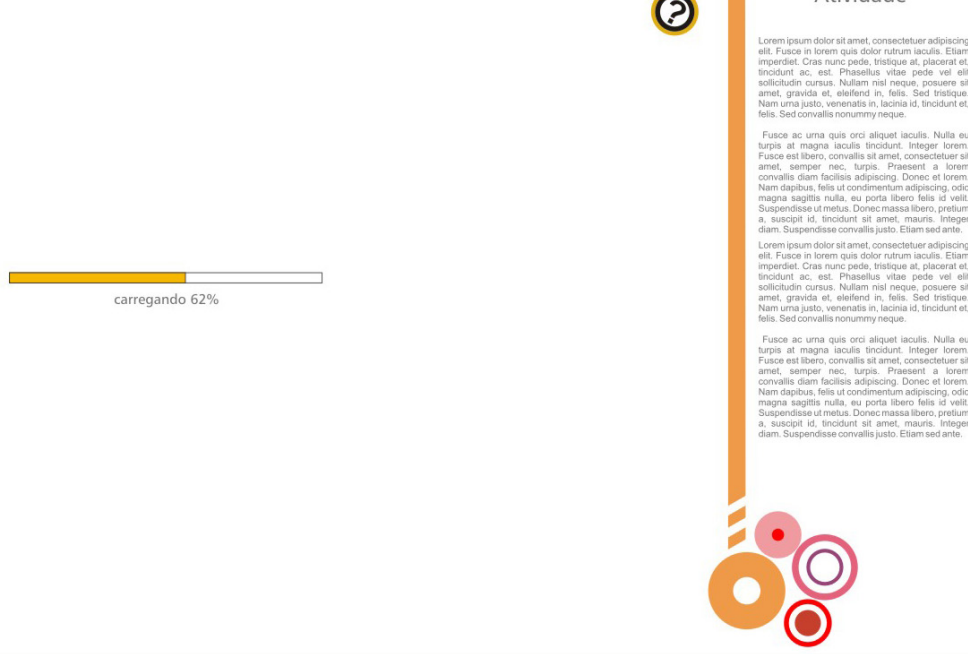

\begin{tabular}{|l|l|l|}
\hline & SIM & NÃO \\
\hline Informação para facilitar a localização do usuário & & \\
\hline Otimização do espaço utilizado & \\
\hline Diferenciação das disciplinas por cor & \\
\hline Direcionar a atenção ao objeto de aprendizagem (animação) & \\
\hline Destaque ao botão ajuda & \\
\hline Destaque ao material de apoio & \\
\hline Destaque ao conteúdo da atividade & \\
\hline Padronização dos botões recorrentes & \\
\hline Remeter à educação & \\
\hline Remeter à informática & \\
\hline Acesso a todo conteúdo do módulo na mesma tela (sem rolagem) & \\
\hline Formas orgânicas e ornamentadas (ondulações e fluidez) & \\
\hline Contraste de cores, objeto/fundo & \\
\hline Variações tonais de uma matiz & \\
\hline Cores chapadas & \\
\hline Tipografia com um grande peso de linha & \\
\hline Padrões de textura geométricos & \\
\hline Ausência de linhas de contorno & \\
\hline
\end{tabular}

Figura 4.10 - Proposta 4 


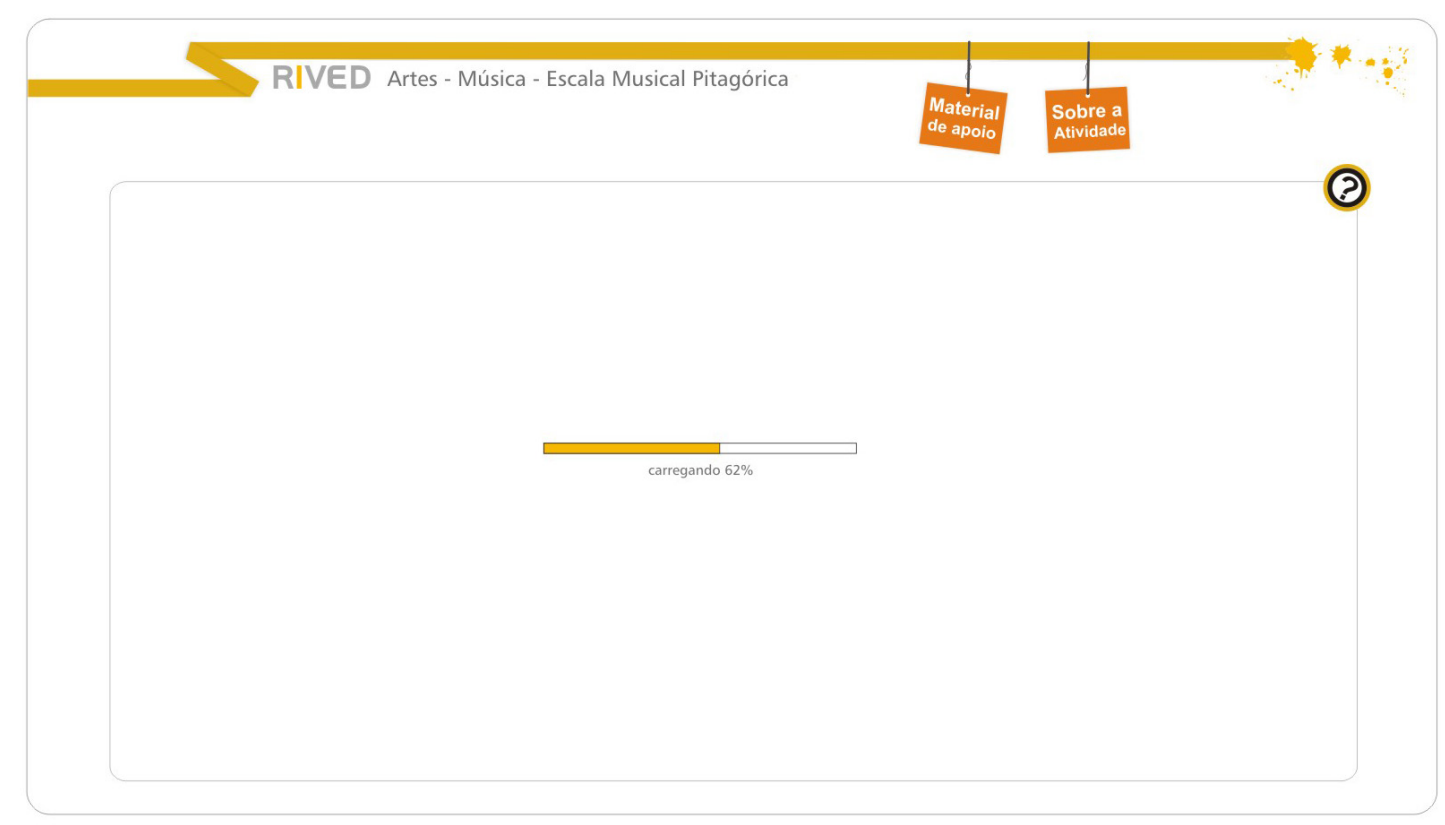

\begin{tabular}{|l|l|l|}
\hline & SIM & NÃO \\
\hline Informação para facilitar a localização do usuário & & \\
\hline Otimização do espaço utilizado & & \\
\hline Diferenciação das disciplinas por cor & & \\
\hline Direcionar a atenção ao objeto de aprendizagem (animação) & \\
\hline Destaque ao botão ajuda & \\
\hline Destaque ao material de apoio & \\
\hline Destaque ao conteúdo da atividade & \\
\hline Padronização dos botões recorrentes & \\
\hline Remeter à educação & \\
\hline Remeter à informática & \\
\hline Acesso a todo conteúdo do módulo na mesma tela (sem rolagem) & \\
\hline Formas orgânicas e ornamentadas (ondulaçães e fluidez) & \\
\hline Contraste de cores, objeto/fundo & \\
\hline Variações tonais de uma matiz & \\
\hline Cores chapadas & \\
\hline Tipografia com um grande peso de linha & \\
\hline Padrões de textura geométricos & \\
\hline Ausência de linhas de contorno & \\
\hline
\end{tabular}

Figura 4.11 - Proposta 5 


\section{MAGIA DOS NÚMEROS}

\section{INTRODUÇÃO}

lorem ipsum dolor sit amet, consectetuer adipiscing elit

Vestibulum egestas, nisi quis accumsan placerat, sem nis consequat pede, eget elemenusto ut nisi.

Aliquam velit diam, egestas at, dignissim nec, fringilla eget, libero. Praesent pellentesque arcu id augue.

Nullam erat lectus, pretium sit amet, tincidunt sit amet, tristique vel, orci. Aenean ultricies

accumsan felis.

Curabitur eros risus, venenatis sit amet, suscipit vel, eleifend id, orci. Sed hendrerit dolor quis elit.

Curabitur lectus diam, hendrerit nec, gravida ut, tempor sed, ante. V

estibulum ante ipsum

primis in faucibus orci luctus et ultrices posuere cubilia Curae;

Praesent feugiat lacus sed laculis malesuada. turpis nequere eleifend sapien. ut luctus urnt

felis in eros. Aenean ipsum leo, ultricies id, viverra sed, lobortis eget, urna.

Aliquam pulvinar ullamcorper enim. Etiam mi tellus, lobortis et, sodales a, viverra sed.

tortor. In luctus dolor vel nulla. Nam lacus.lorem ipsum dolor sit amet, consectetuer adipt

scing elit.

estibulum egestas, nisi quis accumsan placerat, sem nis consequat pede, eget elemen

um nulla justo ut nisi.

Aliquam velit diam, egestas at, dignissim nec, fringilla eget, libero. Praesent pellentesque

arcu id augue

Nullam erat lectus, pretium sit amet, tincidunt sit amet, tristigue vel, orci. Aenen ultricies

ccumsan felis.

Curabitur eros risus, venenatis sit amet, suscipit vel, eleifend id, orci. Sed hendrerit dolor quis elit.

\begin{tabular}{|l|l|l|}
\hline & SIM & NÃO \\
\hline Informação para facilitar a localização do usuário & & \\
\hline Otimização do espaço utilizado & & \\
\hline Diferenciação das disciplinas por cor & & \\
\hline Direcionar a atenção ao objeto de aprendizagem (animação) & & \\
\hline Destaque ao botão ajuda & & \\
\hline Destaque ao material de apoio & \\
\hline Destaque ao conteúdo da atividade & \\
\hline Padronização dos botões recorrentes & \\
\hline Remeter à educação & \\
\hline Remeter à informática & \\
\hline Acesso a todo conteúdo do módulo na mesma tela (sem rolagem) & \\
\hline Formas orgânicas e ornamentadas (ondulações e fluidez) & \\
\hline Contraste de cores, objeto/fundo & \\
\hline Variações tonais de uma matiz & \\
\hline Cores chapadas & \\
\hline Tipografia com um grande peso de linha & \\
\hline Padrões de textura geométricos & \\
\hline Ausência de linhas de contorno & \\
\hline
\end{tabular}

Figura 4.12 - Proposta 6 


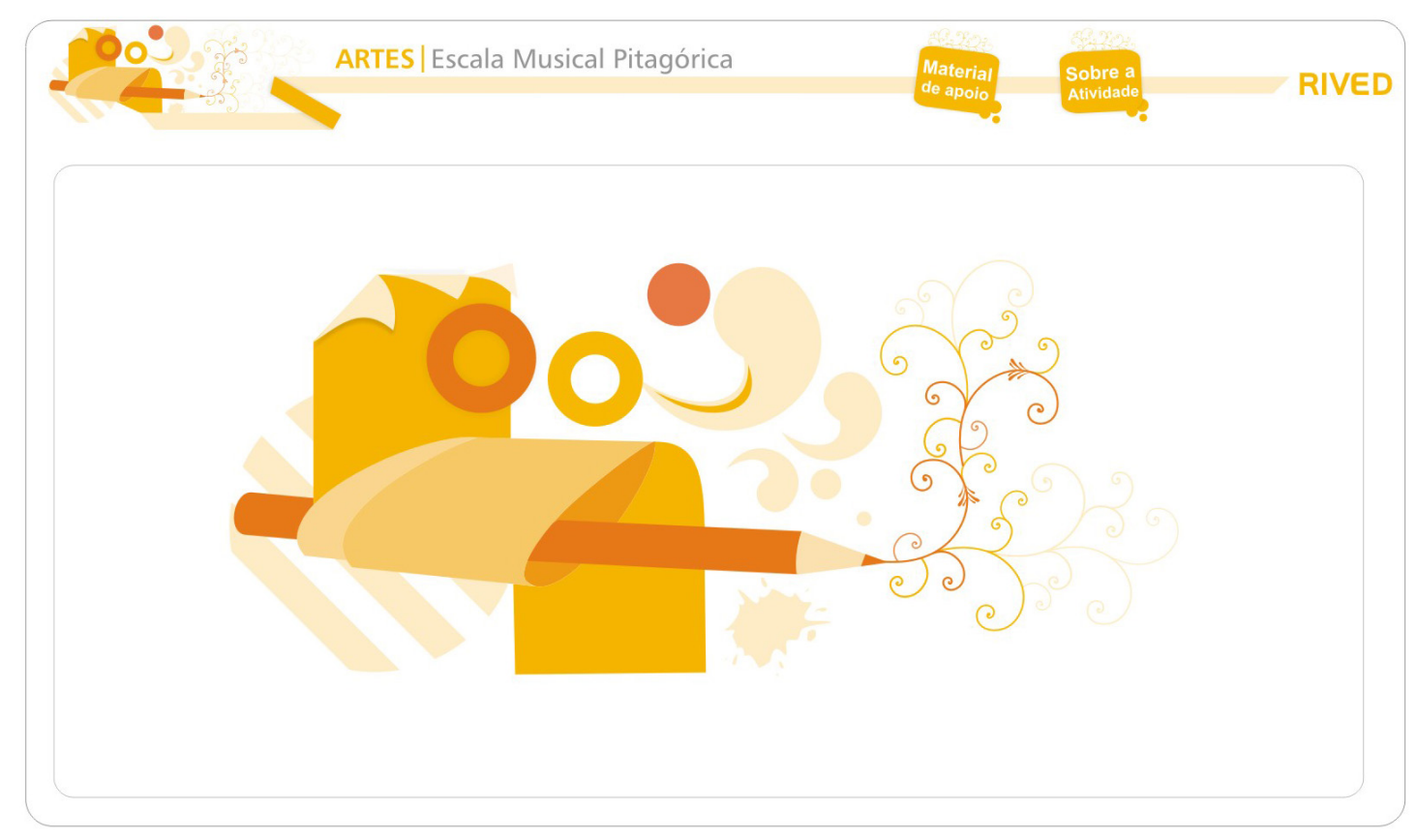

\begin{tabular}{|l|l|l|}
\hline & SIM & NÃO \\
\hline Informação para facilitar a localização do usuário & & \\
\hline Otimização do espaço utilizado & & \\
\hline Diferenciação das disciplinas por cor & & \\
\hline Direcionar a atenção ao objeto de aprendizagem (animação) & & \\
\hline Destaque ao botão ajuda & & \\
\hline Destaque ao material de apoio & \\
\hline Destaque ao conteúdo da atividade & \\
\hline Padronização dos botões recorrentes & \\
\hline Remeter à educação & \\
\hline Remeter à informática & \\
\hline Acesso a todo conteúdo do módulo na mesma tela (sem rolagem) & \\
\hline Formas orgânicas e ornamentadas (ondulações e fluidez) & \\
\hline Contraste de cores, objeto/fundo & \\
\hline Variações tonais de uma matiz & \\
\hline Cores chapadas & \\
\hline Tipografia com um grande peso de linha & \\
\hline Padrões de textura geométricos & \\
\hline Ausência de linhas de contorno & \\
\hline
\end{tabular}

Figura 4.13 - Proposta 7 


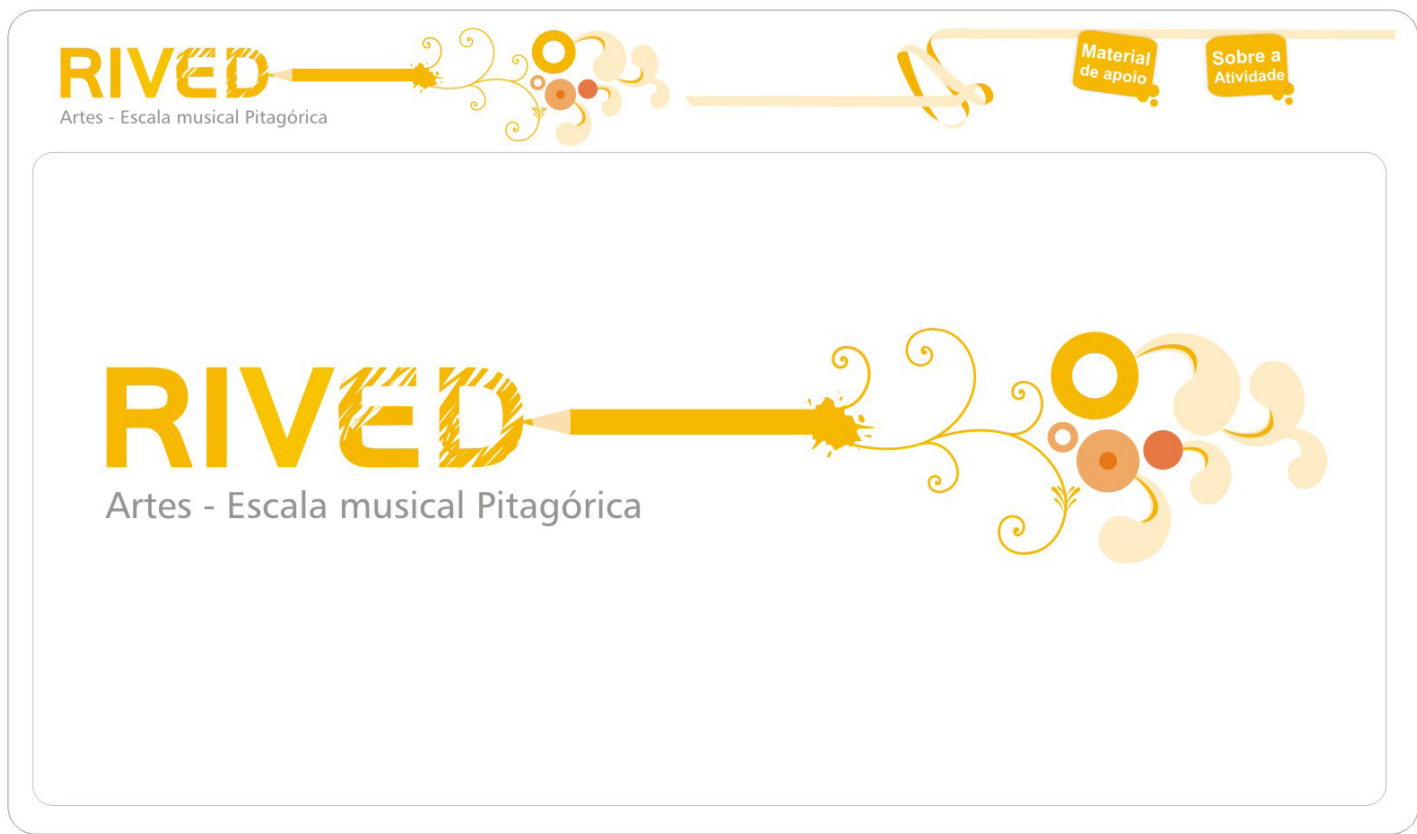

\begin{tabular}{|l|l|l|}
\hline & SIM & NÃO \\
\hline Informação para facilitar a localização do usuário & & \\
\hline Otimização do espaço utilizado & & \\
\hline Diferenciação das disciplinas por cor & & \\
\hline Direcionar a atenção ao objeto de aprendizagem (animação) & & \\
\hline Destaque ao botão ajuda & & \\
\hline Destaque ao material de apoio & \\
\hline Destaque ao conteúdo da atividade & \\
\hline Padronização dos botões recorrentes & \\
\hline Remeter à educação & \\
\hline Remeter à informática & \\
\hline Acesso a todo conteúdo do módulo na mesma tela (sem rolagem) & \\
\hline Formas orgânicas e ornamentadas (ondulações e fluidez) & \\
\hline Contraste de cores, objeto/fundo & \\
\hline Variações tonais de uma matiz & \\
\hline Cores chapadas & \\
\hline Tipografia com um grande peso de linha & \\
\hline Padrões de textura geométricos & \\
\hline Ausência de linhas de contorno & \\
\hline
\end{tabular}

Figura 4.14 - Proposta 8 


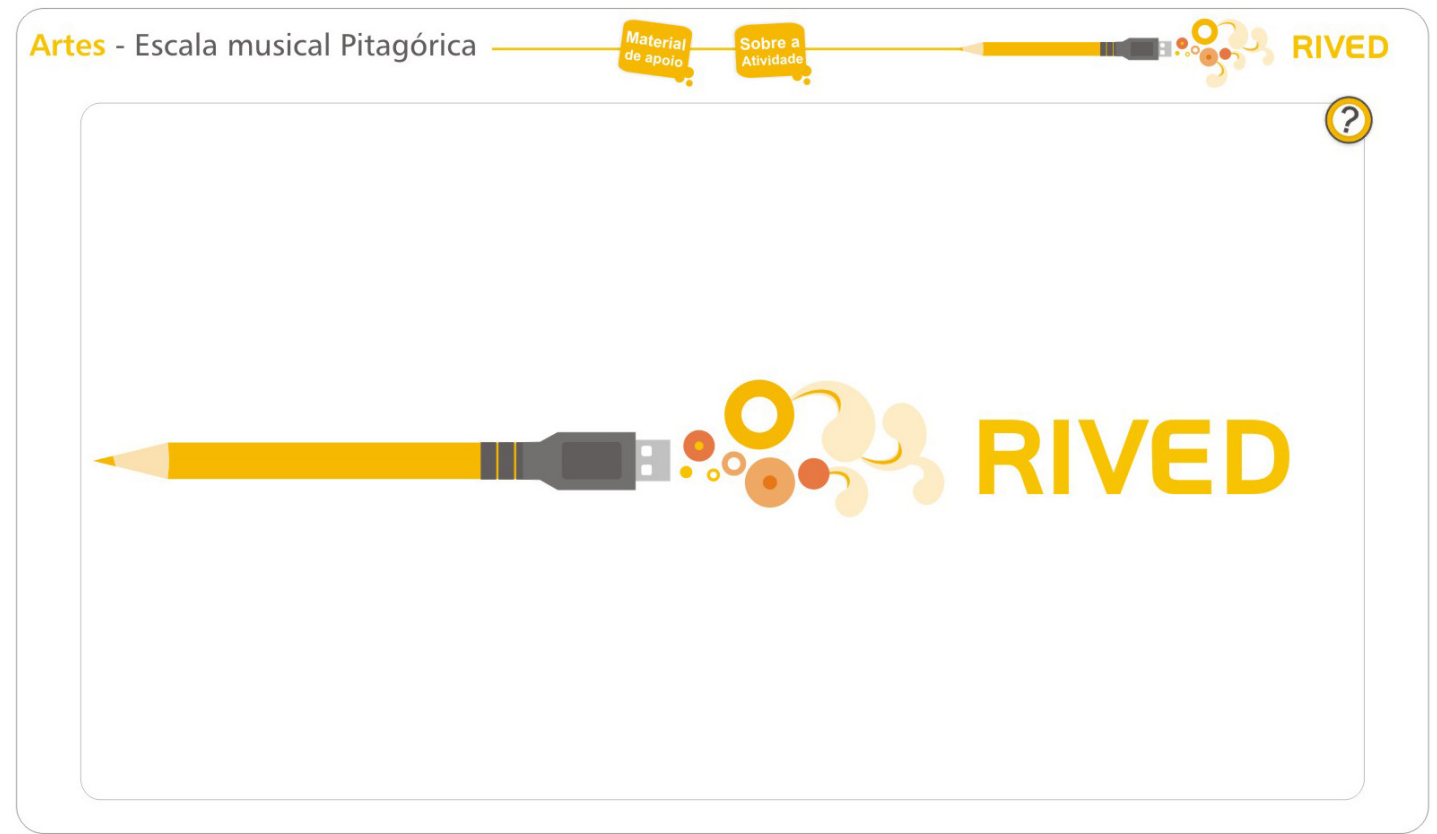

\begin{tabular}{|l|l|l|}
\hline & SIM & NÃO \\
\hline Informação para facilitar a localização do usuário & & \\
\hline Otimização do espaço utilizado & & \\
\hline Diferenciação das disciplinas por cor & & \\
\hline Direcionar a atenção ao objeto de aprendizagem (animação) & & \\
\hline Destaque ao botão ajuda & & \\
\hline Destaque ao material de apoio & \\
\hline Destaque ao conteúdo da atividade & \\
\hline Padronização dos botões recorrentes & \\
\hline Remeter à educação & \\
\hline Remeter à informática & \\
\hline Acesso a todo conteúdo do módulo na mesma tela (sem rolagem) & \\
\hline Formas orgânicas e ornamentadas (ondulações e fluidez) & \\
\hline Contraste de cores, objeto/fundo & \\
\hline Variações tonais de uma matiz & \\
\hline Cores chapadas & \\
\hline Tipografia com um grande peso de linha & \\
\hline Padrões de textura geométricos & \\
\hline Ausência de linhas de contorno & \\
\hline
\end{tabular}

Figura 4.15 - Proposta 9 


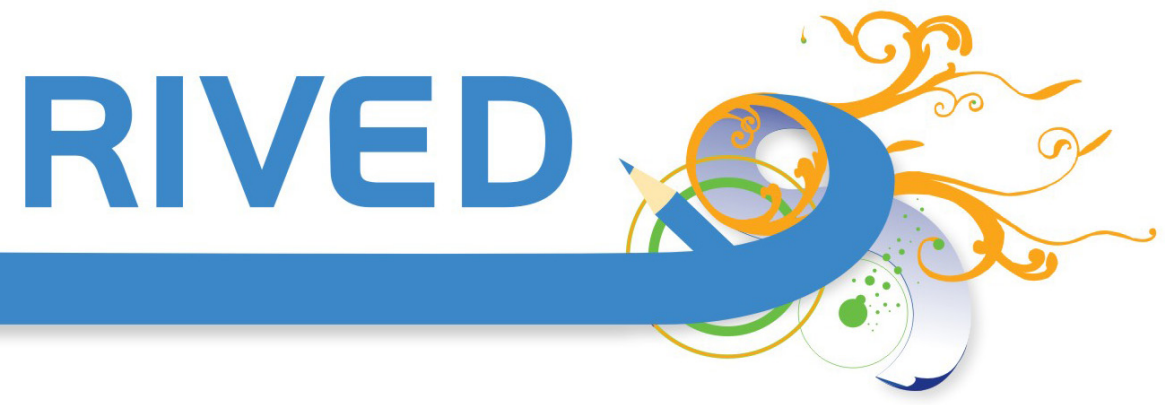

\begin{tabular}{|l|l|l|}
\hline & SIM & NÃO \\
\hline Informação para facilitar a localização do usuário & & \\
\hline Otimização do espaço utilizado & & \\
\hline Diferenciação das disciplinas por cor & & \\
\hline Direcionar a atenção ao objeto de aprendizagem (animação) & \\
\hline Destaque ao botão ajuda & \\
\hline Destaque ao material de apoio & \\
\hline Destaque ao conteúdo da atividade & \\
\hline Padronização dos botões recorrentes & \\
\hline Remeter à educação & \\
\hline Remeter à informática & \\
\hline Acesso a todo conteúdo do módulo na mesma tela (sem rolagem) & \\
\hline Formas orgânicas e ornamentadas (ondulações e fluidez) & \\
\hline Contraste de cores, objeto/fundo & \\
\hline Variações tonais de uma matiz & \\
\hline Cores chapadas & \\
\hline Tipografia com um grande peso de linha & \\
\hline Padrões de textura geométricos & \\
\hline Ausência de linhas de contorno & \\
\hline
\end{tabular}

Figura 4.16 - Proposta 10 


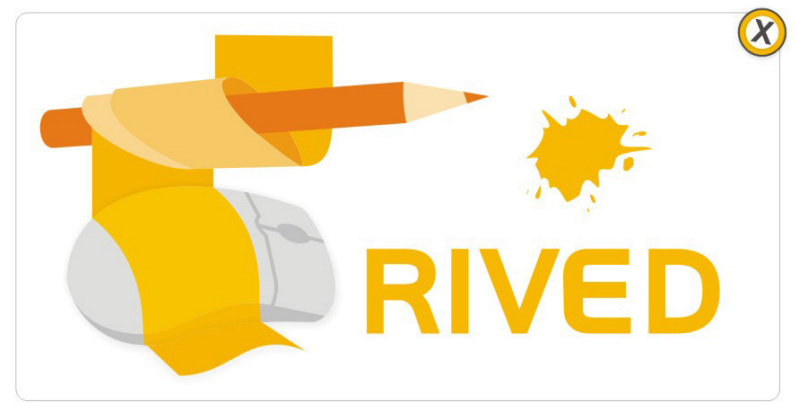

\begin{tabular}{|l|l|l|}
\hline & SIM & NÃO \\
\hline Informação para facilitar a localização do usuário & & \\
\hline Otimização do espaço utilizado & & \\
\hline Diferenciação das disciplinas por cor & & \\
\hline Direcionar a atenção ao objeto de aprendizagem (animação) & & \\
\hline Destaque ao botão ajuda & & \\
\hline Destaque ao material de apoio & \\
\hline Destaque ao conteúdo da atividade & \\
\hline Padronização dos botões recorrentes & \\
\hline Remeter à educação & \\
\hline Remeter à informática & \\
\hline Acesso a todo conteúdo do módulo na mesma tela (sem rolagem) & \\
\hline Formas orgânicas e ornamentadas (ondulações e fluidez) & \\
\hline Contraste de cores, objeto/fundo & \\
\hline Variações tonais de uma matiz & \\
\hline Cores chapadas & \\
\hline Tipografia com um grande peso de linha & \\
\hline Padrões de textura geométricos & \\
\hline Ausência de linhas de contorno & \\
\hline
\end{tabular}

Figura 4.17 - Proposta 11 

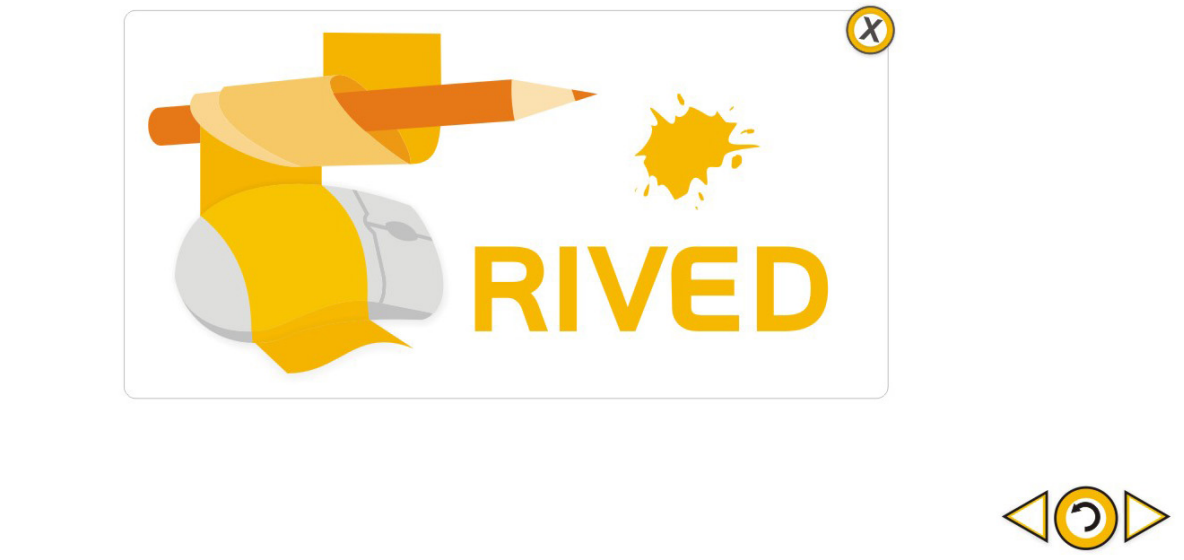

\begin{tabular}{|l|l|l|}
\hline & SIM & NÃO \\
\hline Informação para facilitar a localização do usuário & \\
\hline Otimização do espaço utilizado & \\
\hline Diferenciação das disciplinas por cor & \\
\hline Direcionar a atenção ao objeto de aprendizagem (animação) & \\
\hline Destaque ao botão ajuda & \\
\hline Destaque ao material de apoio & \\
\hline Destaque ao conteúdo da atividade & \\
\hline Padronização dos botões recorrentes & \\
\hline Remeter à educação & \\
\hline Remeter à informática & \\
\hline Acesso a todo conteúdo do módulo na mesma tela (sem rolagem) & \\
\hline Formas orgânicas e ornamentadas (ondulações e fluidez) & \\
\hline Contraste de cores, objeto/fundo & \\
\hline Variações tonais de uma matiz & \\
\hline Cores chapadas & \\
\hline Tipografia com um grande peso de linha & \\
\hline Padrões de textura geométricos & \\
\hline Ausência de linhas de contorno & \\
\hline
\end{tabular}

Figura 4.18 - Proposta 12

\section{Alternativa selecionada}

A proposta 12 (fig.4.18) foi a que mais se adequou aos pré-requisitos. Foram satisfeitos todos os pré-requisitos obrigatórios (grupo1) e desejáveis (grupo2). Apenas dois pré-requisitos do grupo 3 não foram satisfeitos.

A simplicidade visual cumpre com o objetivo de não desviar o foco de atenção para a animação. A área de animação foi estendida em relação ao padrão adotado pelo RIVED. A barra superior proporciona o acesso a todo conteúdo do módulo (material de apoio e explicação sobre a atividade). Do ponto de vista estético 
está adequado ao painel de estilo do usuário, além de remeter à educação e à informática.

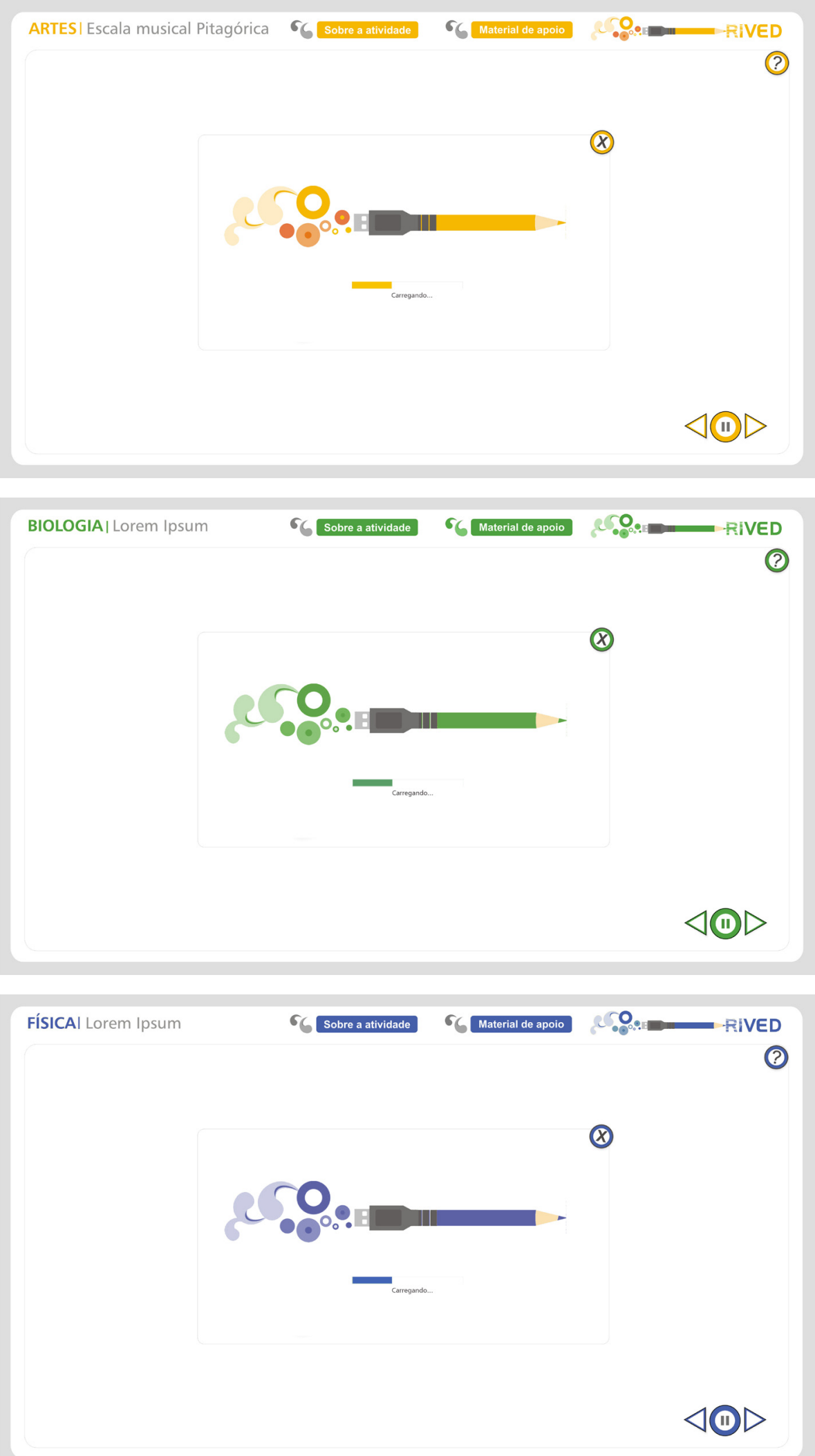




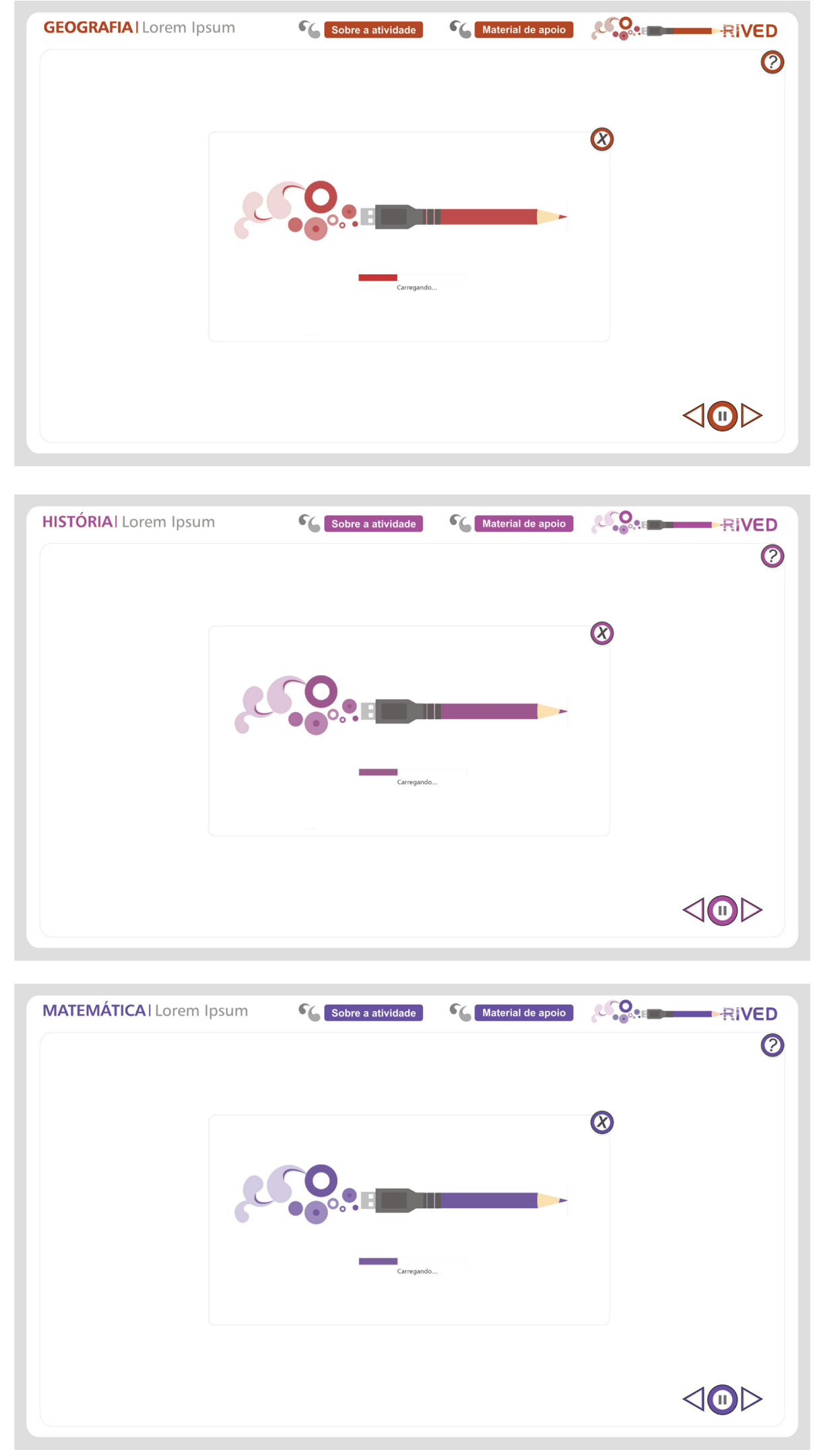


(ब)

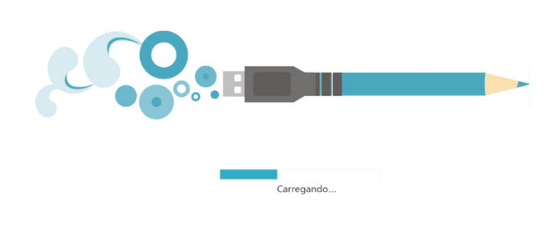

\section{$\triangle$ (11) $>$}

Figura 4.19 - Aplicação de cores da alternativa escolhida

\subsection{Alternativas para os botões de navegação}

De acordo com os estudos realizados sobre os botões mais familiares ao usuário e a recorrência dos botões de navegação nas animações do RIVED iniciou-se a geração de alternativas relativa a esses botões.

Foram definidos três botões principais: avançar, reiniciar a animação e voltar. Tentou-se adequar a concepção desses botões à lista de pré-requisitos (cap.3).
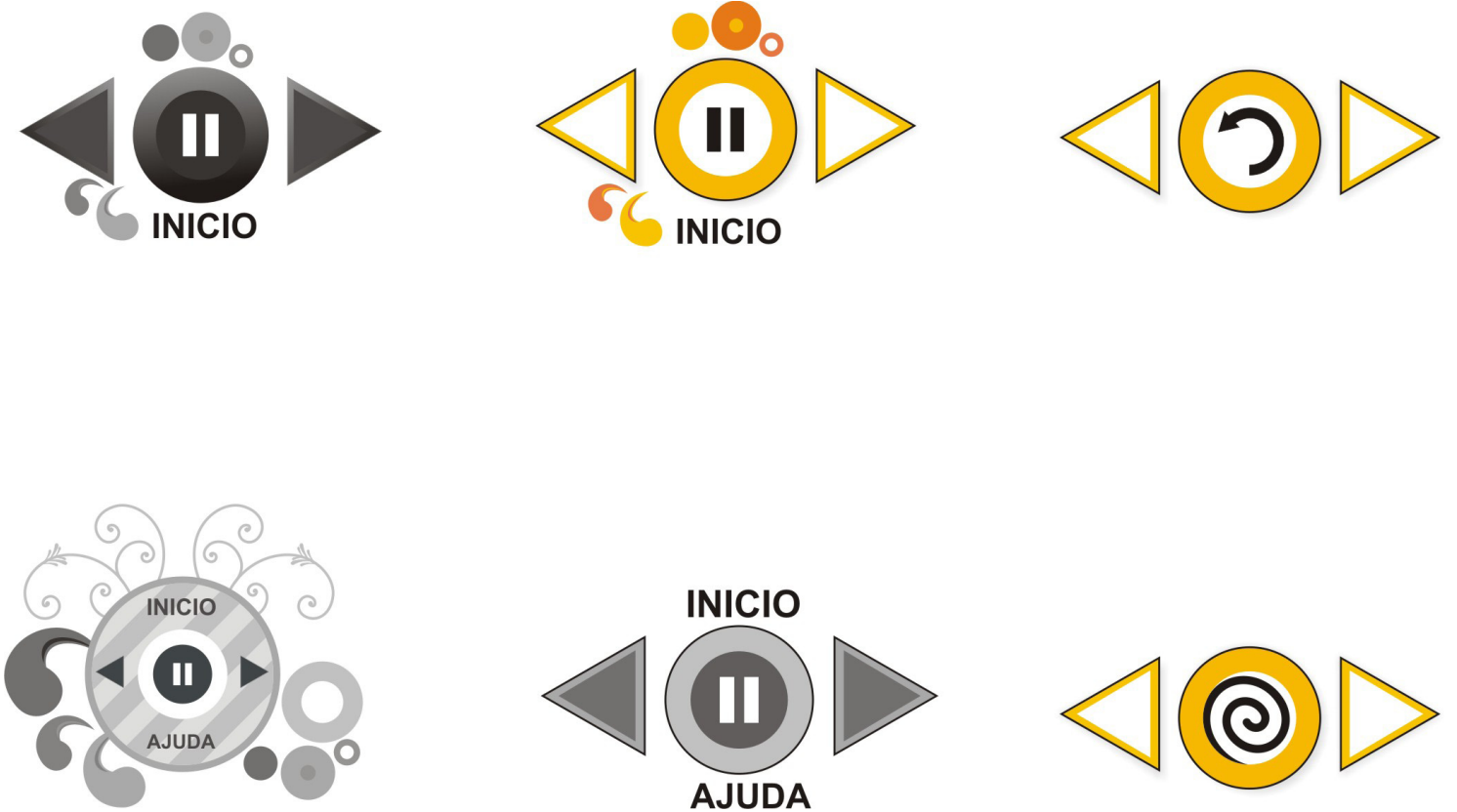

Figura 4.20 - Alternativas para botões de navegação

\section{Alternativa selecionada}

Foi selecionado o botão constante da Figura 4.20 por ocupar uma área pequena do palco da animação, por sua coerência com o padrão apresentado neste projeto, por ser extremamente intuitivo no cumprimento das funções voltar, 
reiniciar e avançar. Deve-se ressaltar que a cor será alterada de acordo com a disciplina (fig.4.1).

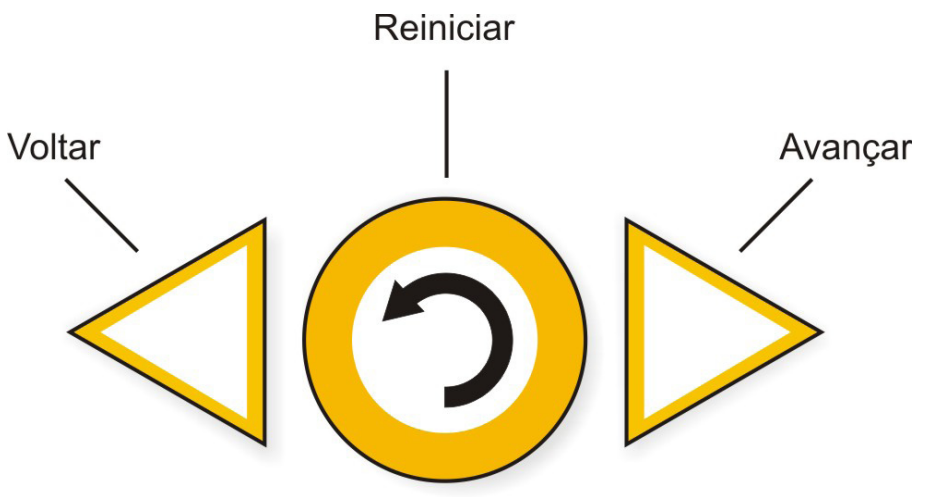

Figura 4.21 - Alternativa selecionada 


\section{Objeto 1 - Escala musical pitagórica}

Este primeiro objeto de aprendizagem está relacionado ao conteúdo de Artes, valendo-se, também, da Matemática. O conteúdo, proposto pelo professor Flávio Ambrosio Campos, trata de uma abordagem matemática sobre o conceito das harmônicas estudado pelo filósofo grego Pitágoras (séc.V ao VI a.C.).

A escala Pitágorica é a base da escala diatônica moderna e influenciou todas as escalas musicais posteriores.Pitágoras considerava o números 3 como uma divindade e o intervalo $3 / 2$ a perfeição musical. Com base nisso Pitágoras construiu todo seu sistema musical (ciclo de quintas).

Por não haver registro histórico preciso sobre como Pitágoras desenvolveu seu sistema musical, para este objeto de aprendizagem, o conteúdo baseou-se na adaptação de uma lenda: Pitágoras caminhava pela rua quando o som dos martelos de ferreiros chamou sua atenção. Ele reparou que havia uma relação entre o peso dos martelos e a nota musical produzida. Resolveu, então, prender martelos de pesos diferentes em cordas idênticas. Percebendo que a relação de peso entre os martelos que geravam um som agradável era justamente potências de 3 e 2, já que todos os intervalos harmônicos derivavam de quintas (3/2) ou oitavas (1/2).

\subsection{Referências estéticas da Grécia Antiga}

[...] no campo da transmissão de imagens, observamos que a qualidade pode ser claramente dividida em dois grupos. De um lado temos a informação pictórica superficial e breve, como a que aparece na imprensa escrita diária e nas reportagens filmadas e do outro lado existe a necessidade de reprodução que aproxime cada vez mais da realidade. (FRUTIGER, 2001, p.196)

A arquitetura, as vestes, o alfabeto grego, imagens atuais sobre a Grécia, estilo de vida etc, foram os principais elementos buscados para a elaboração e a abordagem mais fidedigna à realidade e ao contexto proposto. 

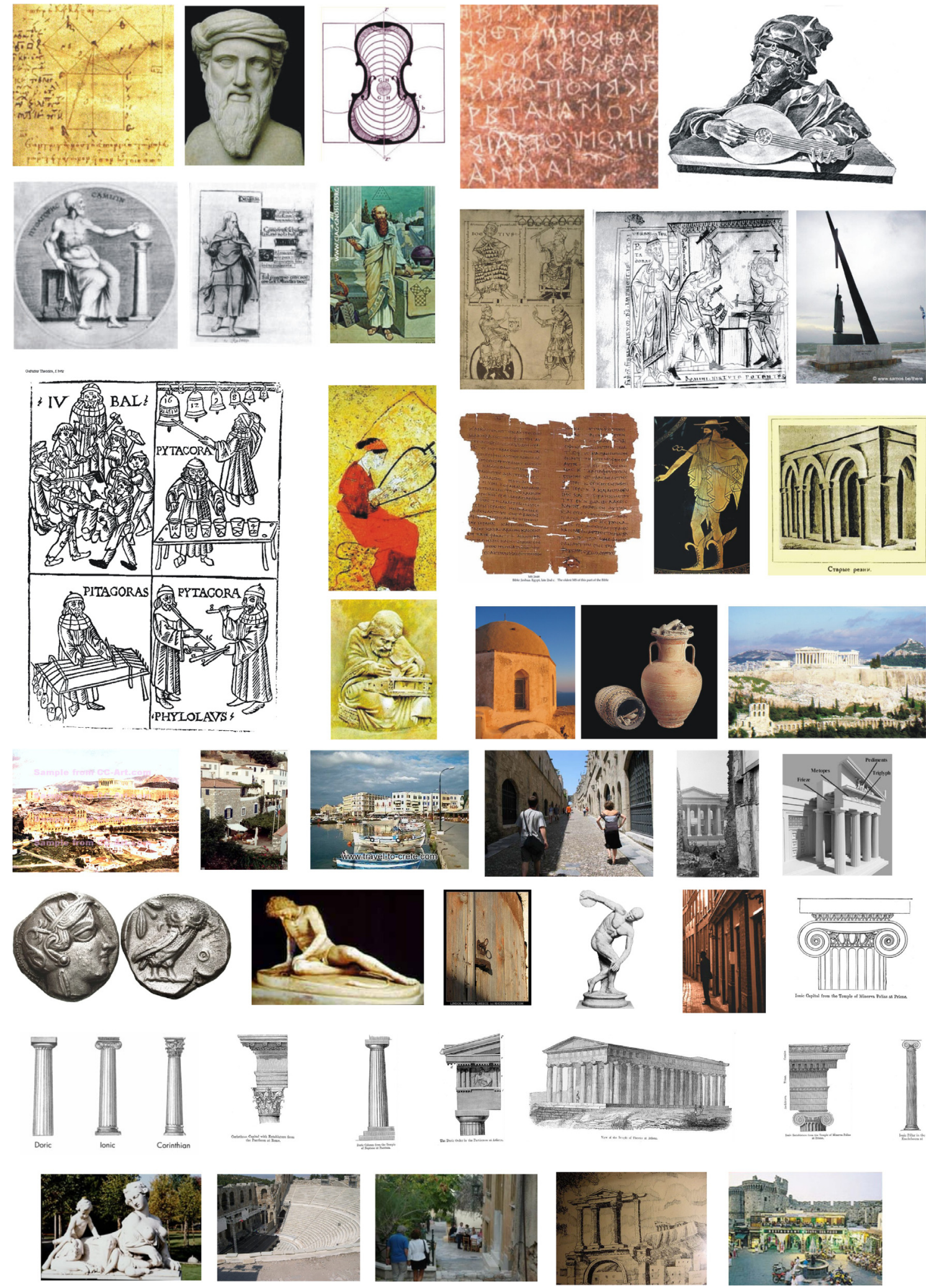

Figura 5.1 - Painel de estilo baseado na cultura grega

A partir das imagens coletadas, produziu-se um painel de estilos com os elementos citados acima e buscou-se sintetizar claramente os que mais seriam condizentes com a elaboração e caracterização do objeto de aprendizagem. O objetivo era a sintetização dos elementos, mantendo as características principais, ou seja, a simplificação e geometrização da forma, tanto para o cenário quanto para os 
personagens, a fim de viabilizar uma linguagem clara e objetiva para o usuário. O intuito era reforçar uma unidade de expressão entre as formas, oferecendo assim melhores condições de apresentação e comunicação.

\subsection{Decupagem e storyboard}

Com base no conteúdo proposto foi elaborado o roteiro e decupado em cenas por meio de um storyboard. O objetivo desse método de esboço do passo-a-passo, é tentar seguir fielmente a narrativa do roteiro, com ilustrações que indiquem trechos da cena a serem desenvolvidas.

As cenas propostas pelo professor responsável (CAMPOS, F. A.) pelo conteúdo foram:

\section{Cena 1}

texto:

- Pitágoras caminha pela rua, quando escuta um som interessante, resolve então investigar...

- Será que você poderia ajudá-lo a encontrar a melhor combinação dos sons?

Imagem:

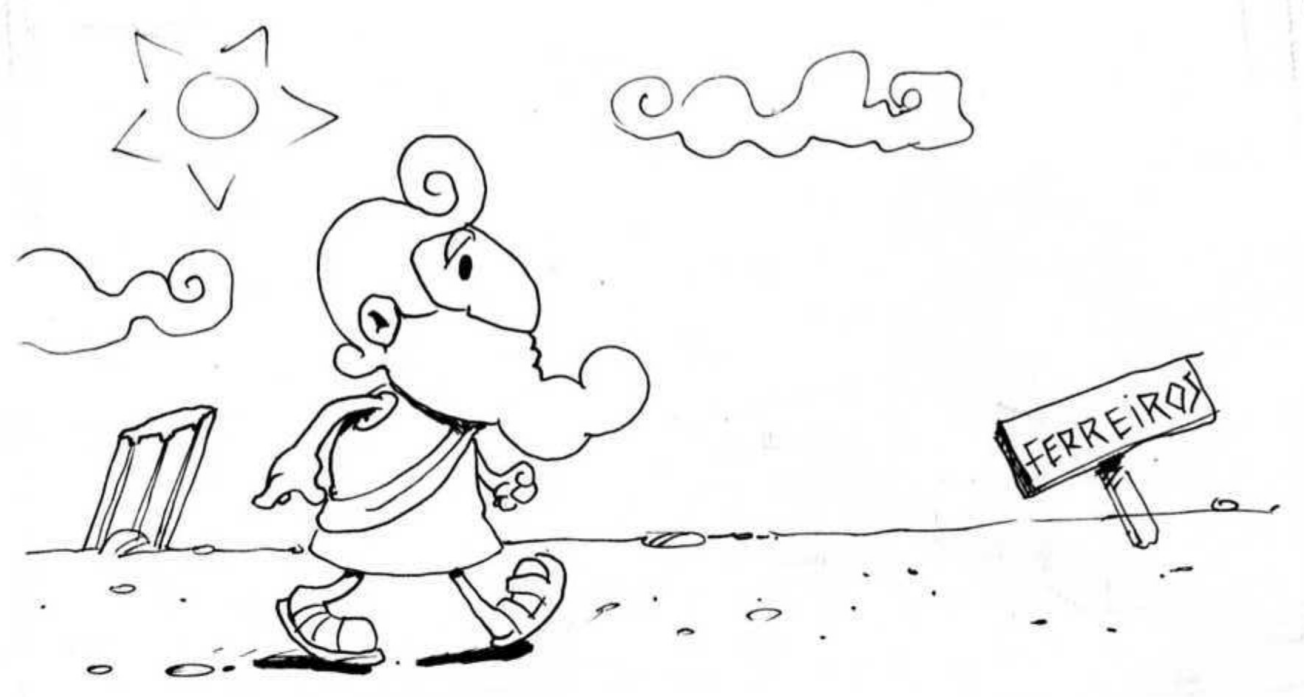

Figura 5.2 - Cena1

\section{Cena 2}

texto:

- Que tal experimentarmos algumas possíveis combinações de martelos e verificar qual delas produz um som mais agradável? 
imagem:

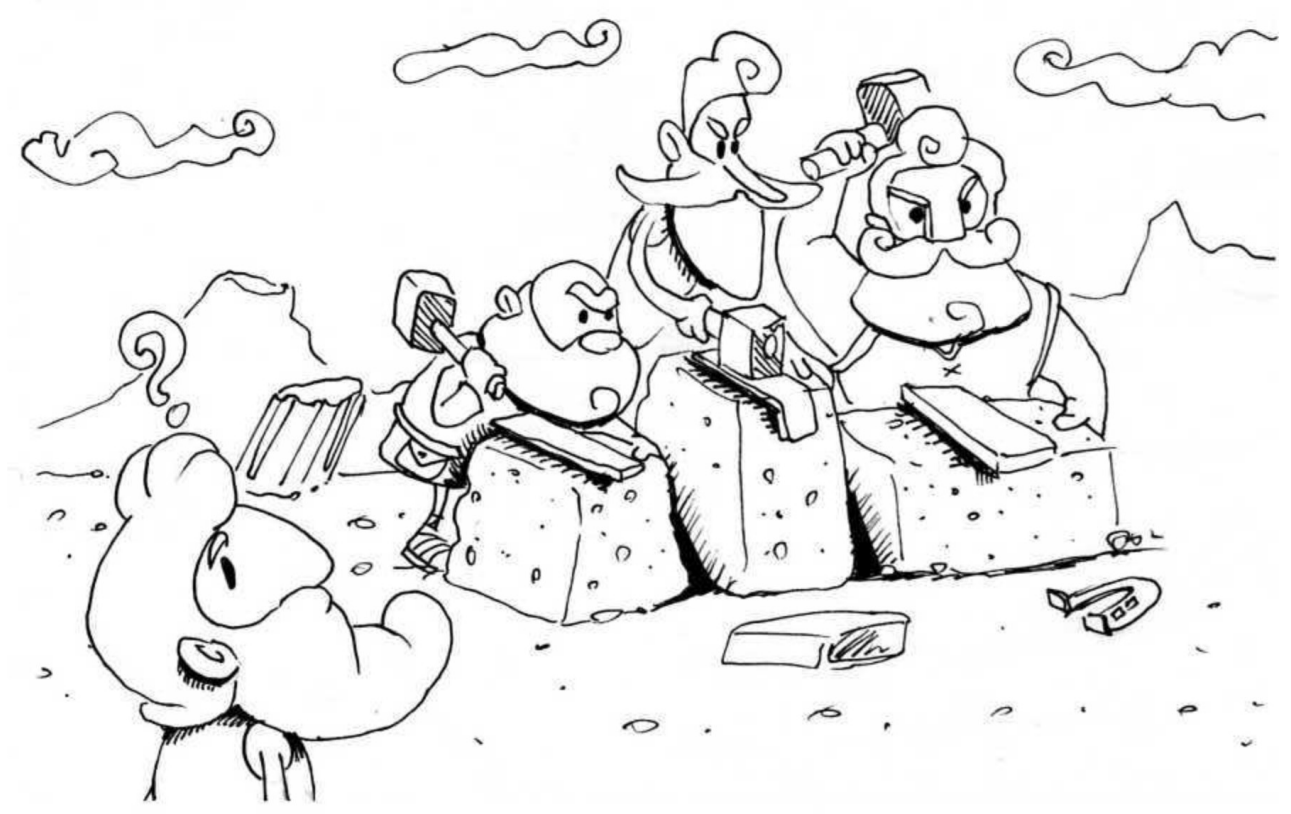

Figura 5.3 - Cena 2

\section{Cena 3}

texto:

- clique sobre os martelos e arraste para a ponta das cordas.

- escolha diferentes combinações de quatro martelos e veja o resultado.

imagem:

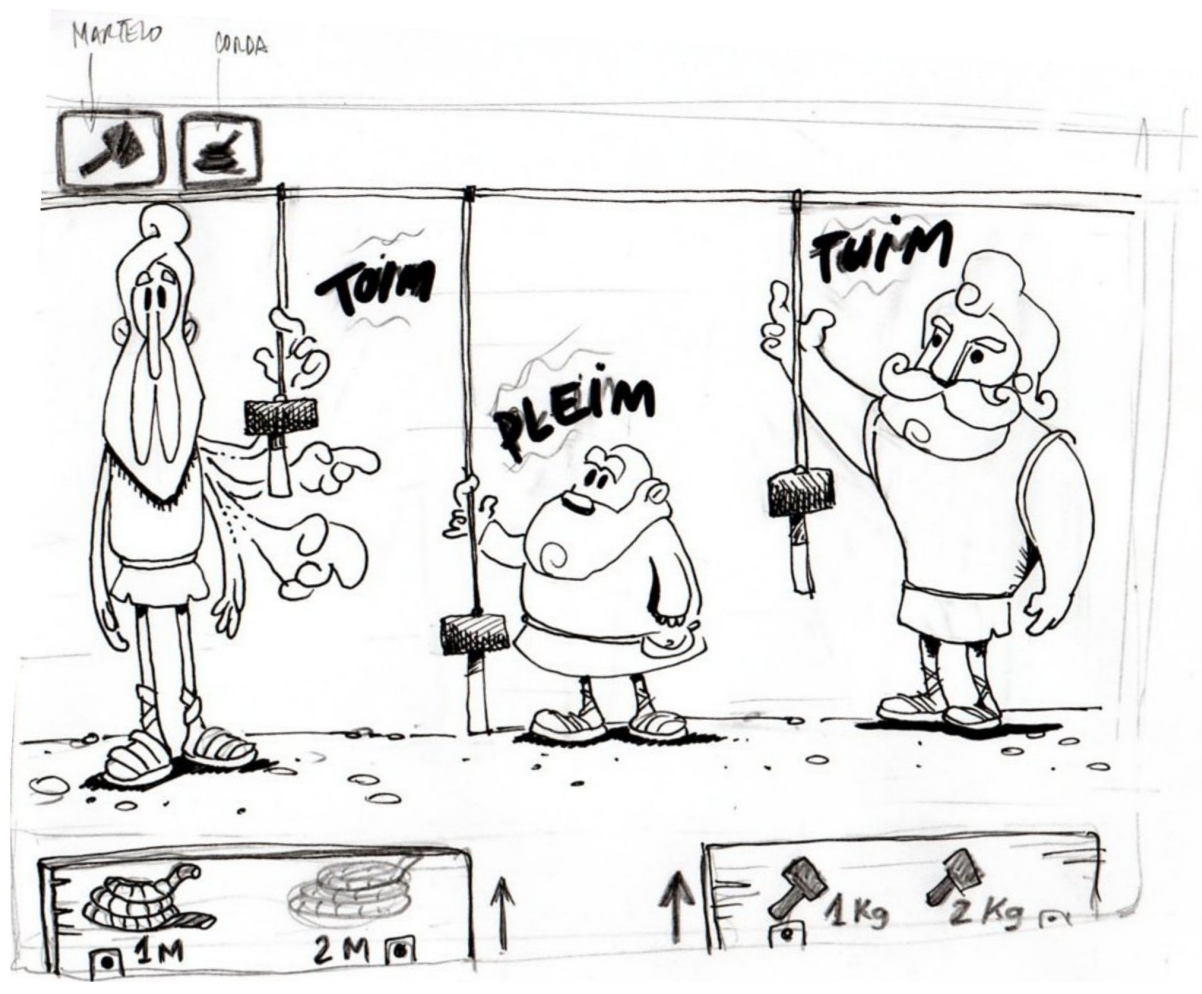

Figura 5.4 - Cena 3 


\section{Cena 4}

texto:

Caso a combinação esteja errada:

- Tente de novo!

Caso a combinação esteja correta:

- Parabéns, você encontrou a combinação perfeita!

Imagem:

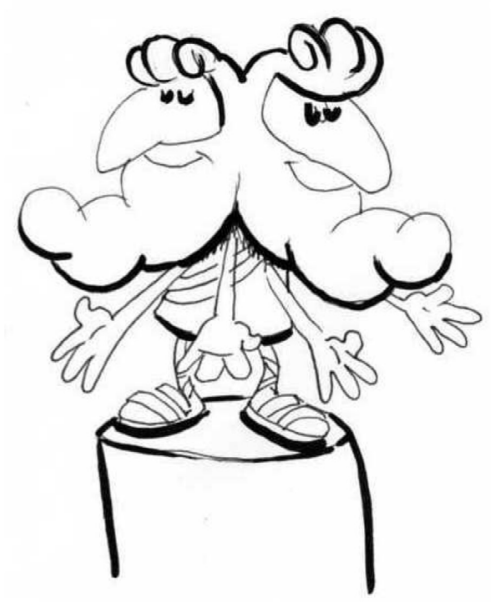

Figura 5.5 - Cena 4

\subsection{Concepção dos personagens}

De acordo com o roteiro (ver tópico 5.3), são cinco personagens em cena (Pitágoras e quatro ferreiros). Foram utilizadas duas técnicas distintas para a animação: a primeira utilizando a animação tradicional 2D,para os ferreiros (Fig.5.8), e a segunda com a utilização da técnica $3 \mathrm{D}$, que vai desde a modelagem tridimensional, texturização, setup de uma estrutura óssea, skinnig associação da malha aos ossos até o render final.

A partir de um conceito dos personagens, usado como guia para a animação, traçou-se um perfil psicológico para os personagens, dando para cada um, uma característica peculiar.

Apenas no protagonista Pitágoras foram utilizadas as técnicas de modelagem e animação em 3D, com a intenção de ressaltar o personagem e diferenciá-lo dos demais dando uma conotação de ser um indivíduo à frente do seu tempo. 

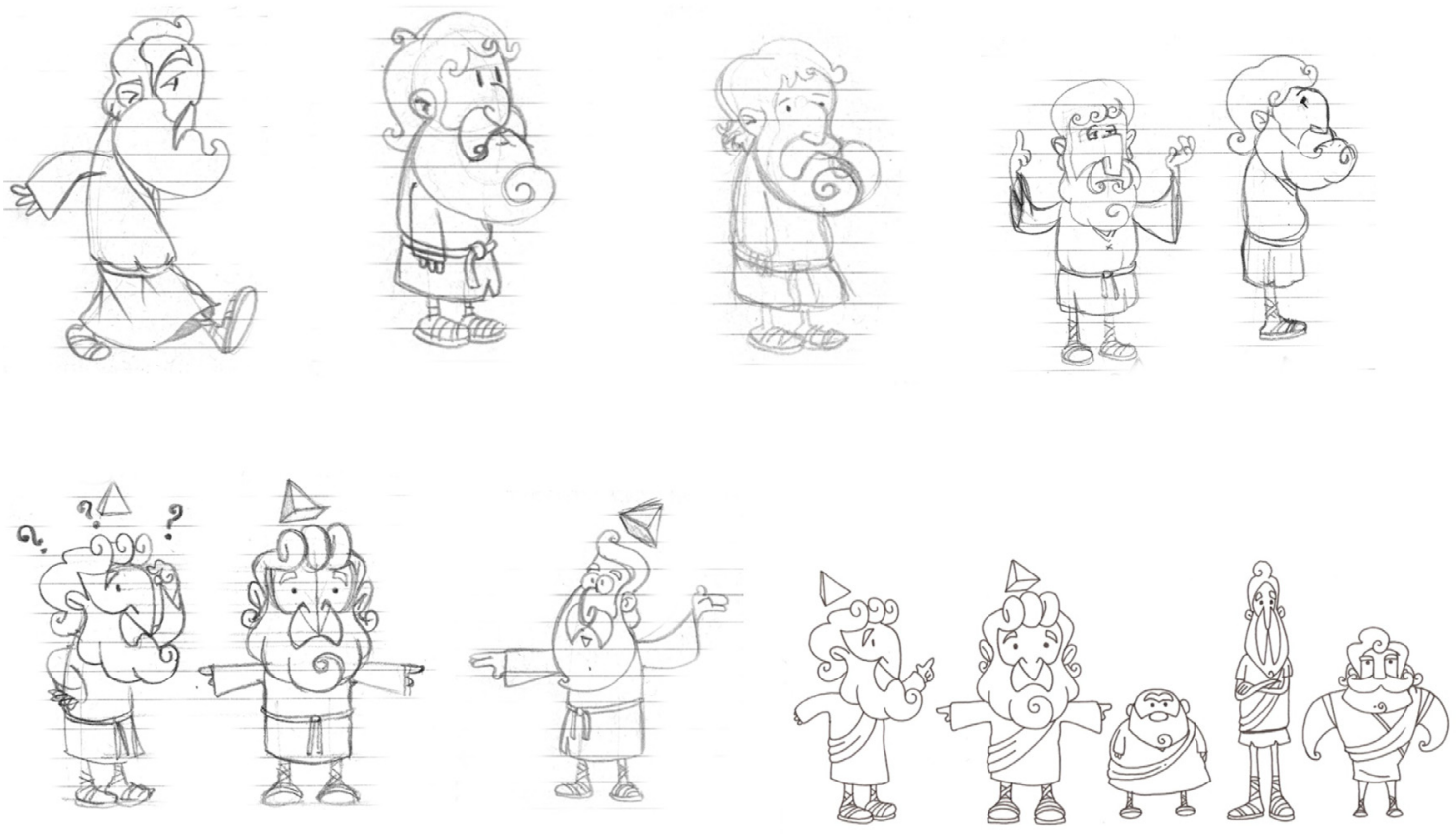

Figura 5.6 - Geração de alternativas paras os personagens
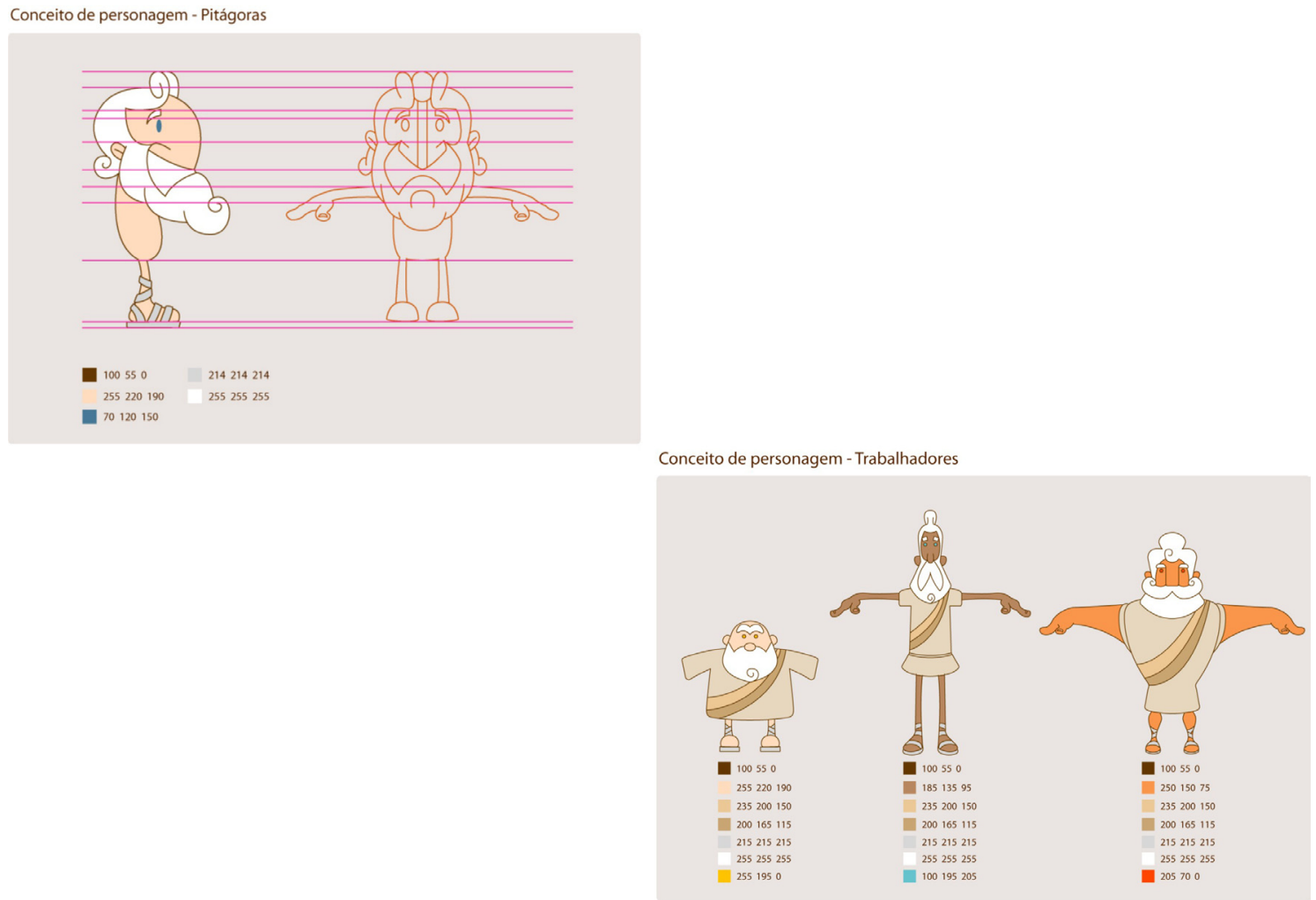

Figura 5.7 - Personagens digitalizados e com padrão cromático definido 

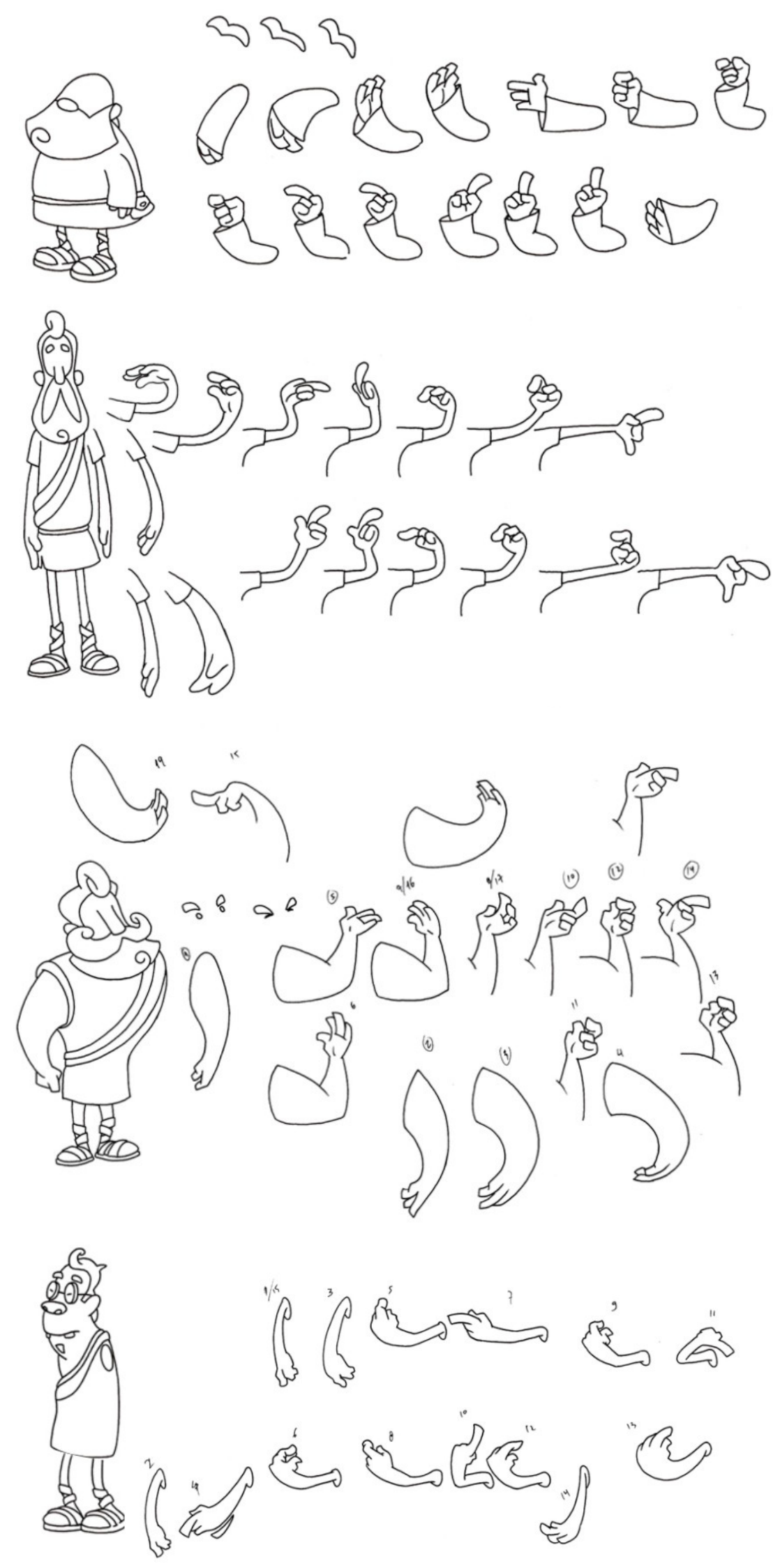

Figura 5.8 - Animação 2D dos ferreiros

60 


\subsubsection{Modelagem 3D do personagem Pitágoras}

A técnica utilizada para a construção do personagem Pitágoras foi a da subdivisão de um poligono básico, no caso um cubo, em vários níveis de detalhamento.

A subdivisão de superfícies é usada para criar superfícies lisas, com arranjos arbitrários. A subdivisão de superfícies é definida como o limite de um processo infinito de refinamento. Foram introduzidos simultaneamente por Edwin Catmull, Jim Clark, Daniel Doo e Malcom Sabin, em 1978. Pouco progresso foi feito até 1995, quando Ulrich Reif resolveu o comportamento da subdivisão de superfícies próximo dos vértices extraordinários. Às vezes é necessário modelar com a geometria já subdividida. Isto permite visualizar o resultado em estágio final, suavizado durante a modelagem. Uma desvantagem é que não se pode focalizar na disposição e na posição dos polígonos da geometria subjacente (ou na gaiola).

Então, a partir do cubo, desenvolve-se a estrututa do personagem baseada no conceito desenhado previamente, com duas vistas: lateral e frontal (fig.5.9) afim de alcançar o estágio final (fig.5.11).
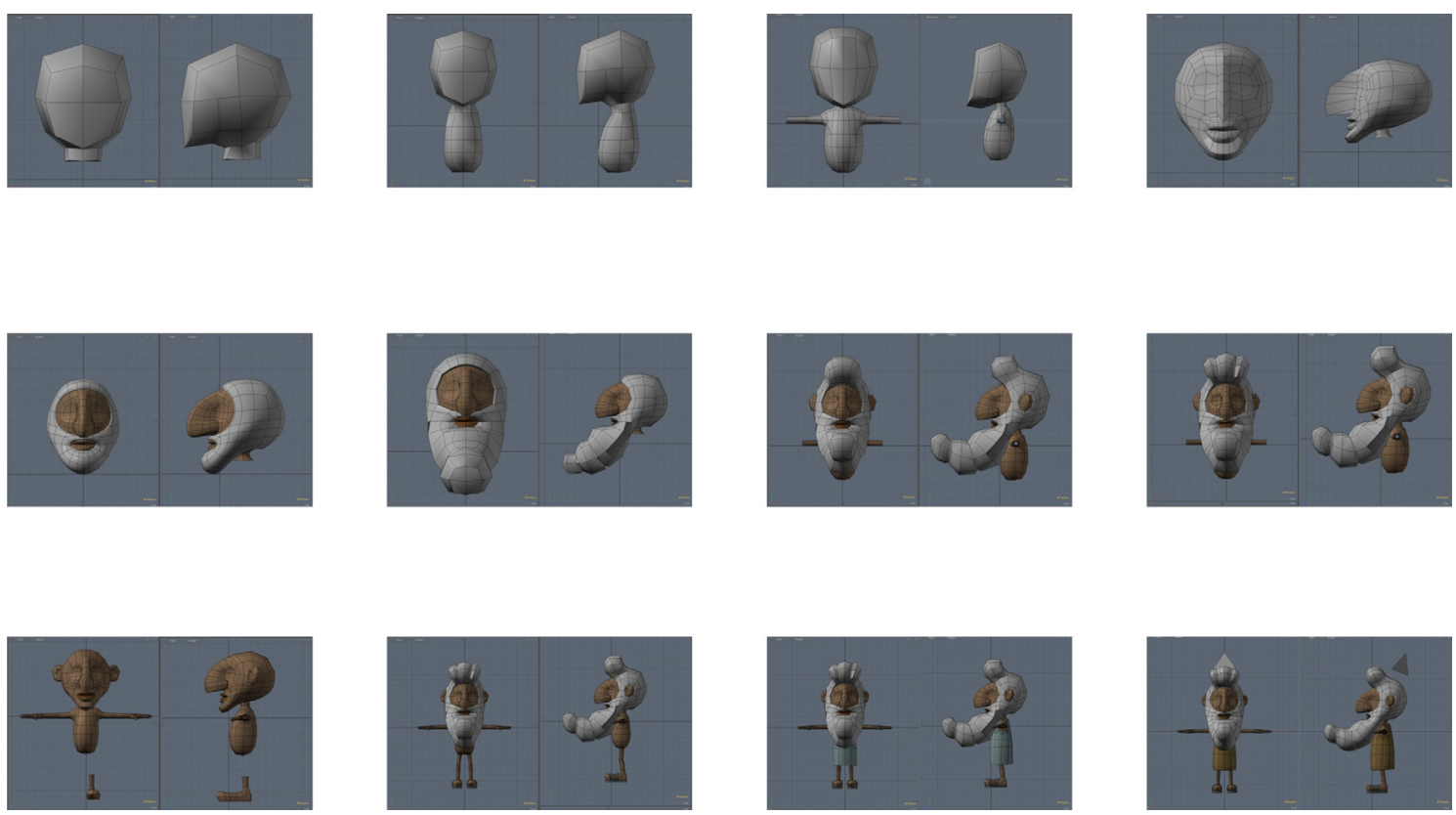

Figura 5.9 - Processo de modelagem subdivisão de polígonos 

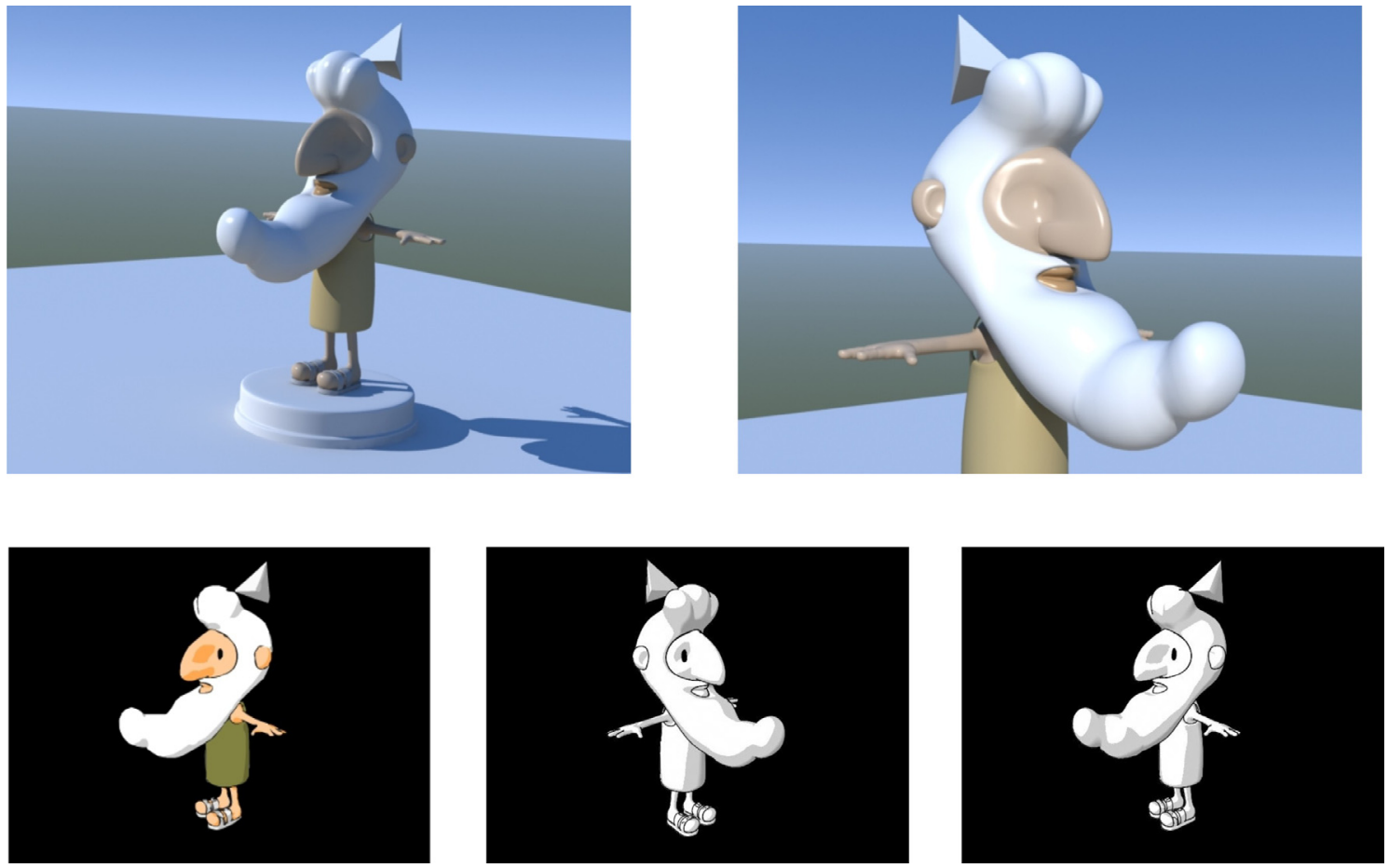

Figura 5.10 - Testes de acabamento

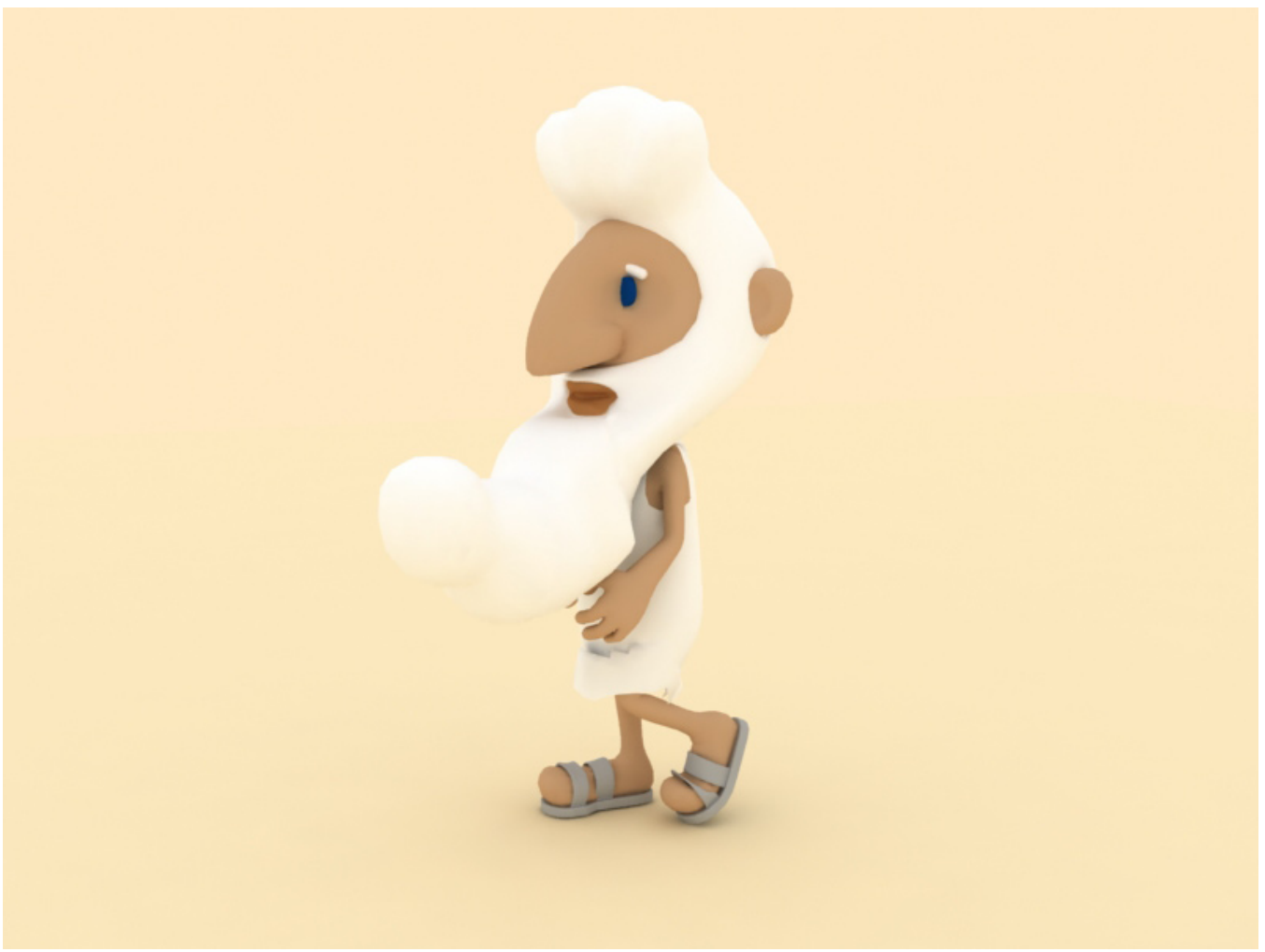

Figura 5.11 - Acabamento final

\subsection{Concepção do cenário}

Com a valorização do traço para os personagens e do uso de cores chapadas para a formação do cenário, tentou-se criar uma aproximação ou referência a 
desenhos que exprimam este tipo de estética, como é o caso de Billyandmandy, Pantera cor-de-rosa e Foster's, ou seja, uma limpeza visual, sem ruídos e com uma perspectiva não-alinhada (fig.5.12).

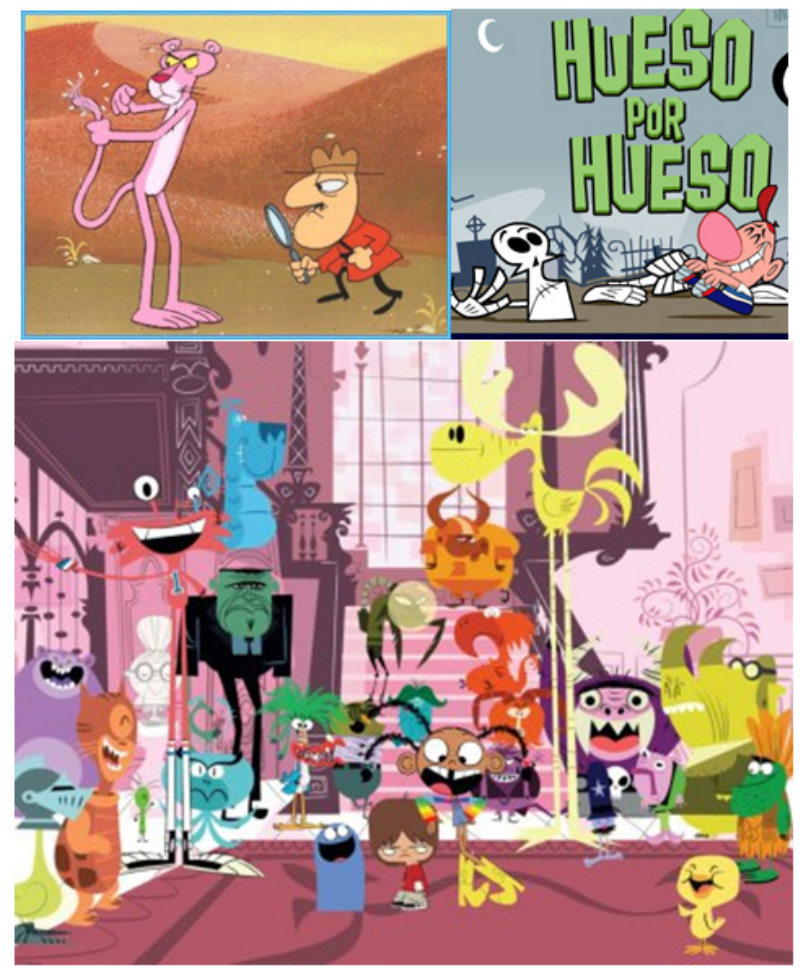

Figura 5.12 - Referência para cenário

A concepção do cenário final baseou-se no estilo arquitetônico da Grécia Antiga, valorizando também a limpeza visual, com a intenção de valorizar os personagens.

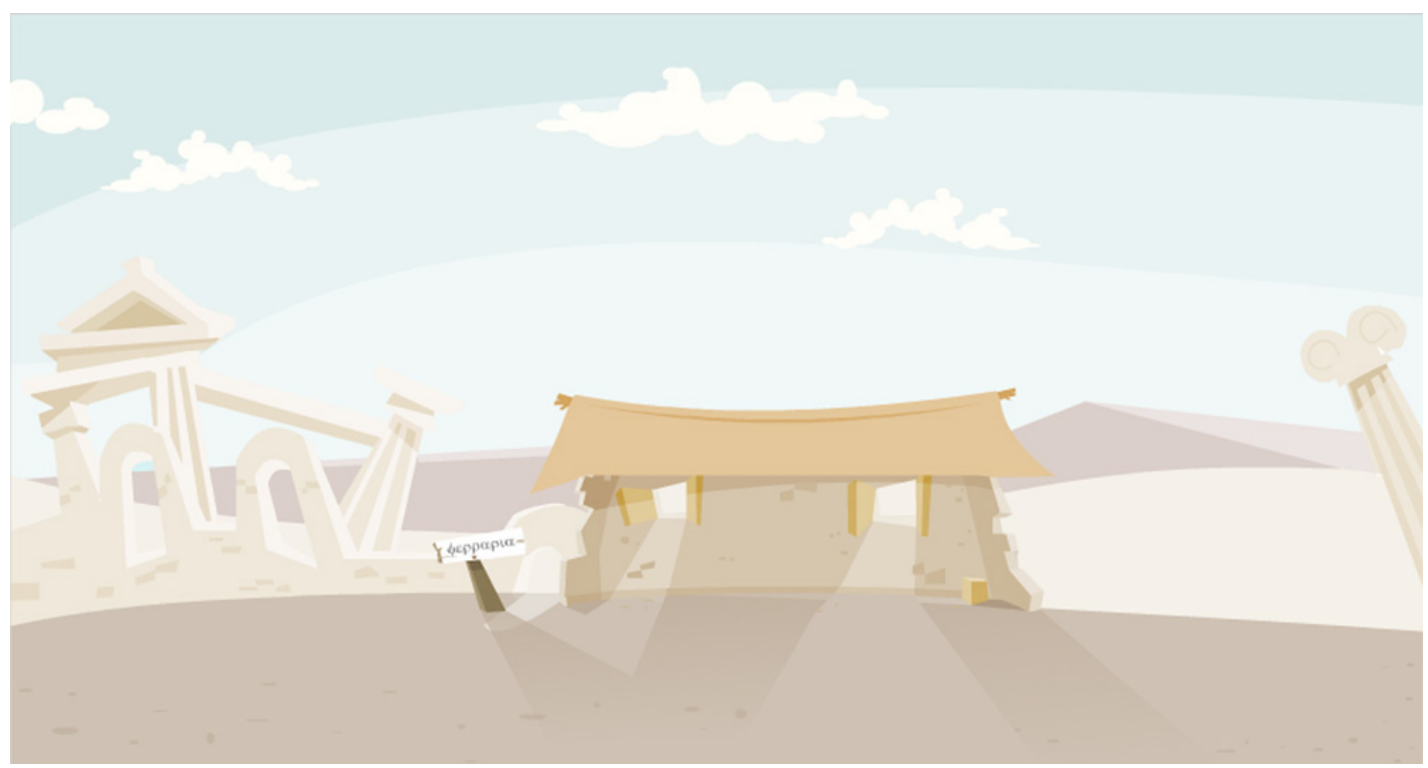

Figura 5.13 - Cenário final 


\subsection{Som para a animação}

Para este objeto de aprendizagem específico o som é parte essencial pra o entendimento do conteúdo, uma vez que o exercício proposto é relacionar as frações dos pesos dos martelos com a relação harmônica das notas produzidas.

Os seguintes sons foram gravados em multipista (Fig.5.14) e mixados para formato em MP3 (MPEG-1/2 Audio Layer 3):

- Violão

- Aplausos

- Martelos

Alguns sons foram obtidos na internet e alterados digitalmente, posteriormente mixados em formato MP3:

- Som do pássaro

- Som do grilo

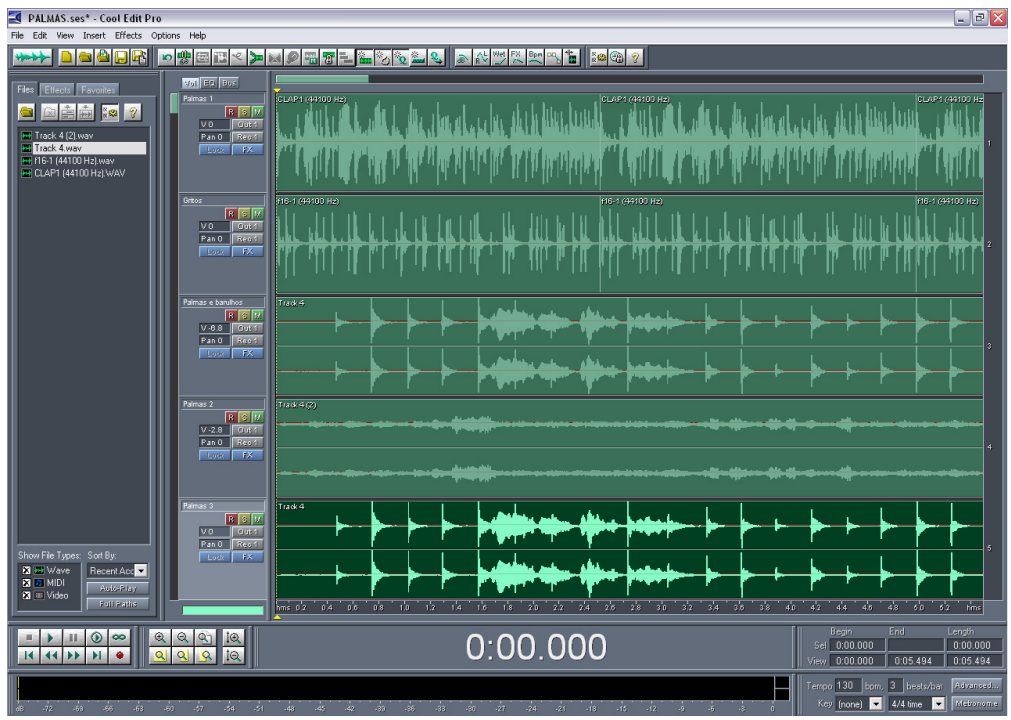

Figura 5.14 - Faixas Multipistas 


\subsection{Objeto de aprendizagem final aplicado ao padrão HTML}

Apresentam-se a seguir as cenas da animação inseridas no padrão HTML proposto neste trabalho.

Em relação ao storyboard algumas cenas foram adicionadas para desenvolver melhor o tema.

A idéia para a cena 1 foi a de um pássaro cantando demonstrando o interesse de Pitágoras pelo acorde produzido pelos martelos, e não pela melodia do canto do pássaro.

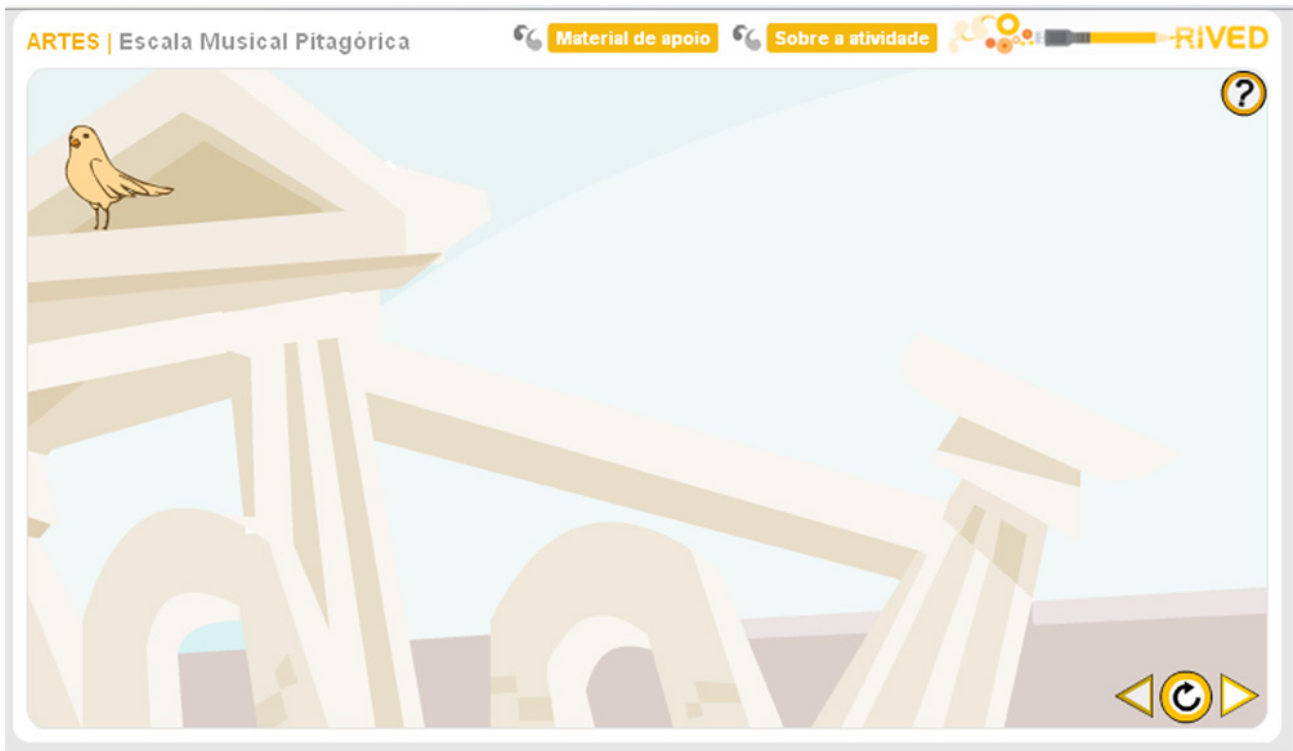

Figura 5.15 - Cena 1

As cenas 2 e 3 estão de acordo com o storyboard, onde Pitágoras escuta o som dos martelos e percebe a relação com seus respectivos pesos.

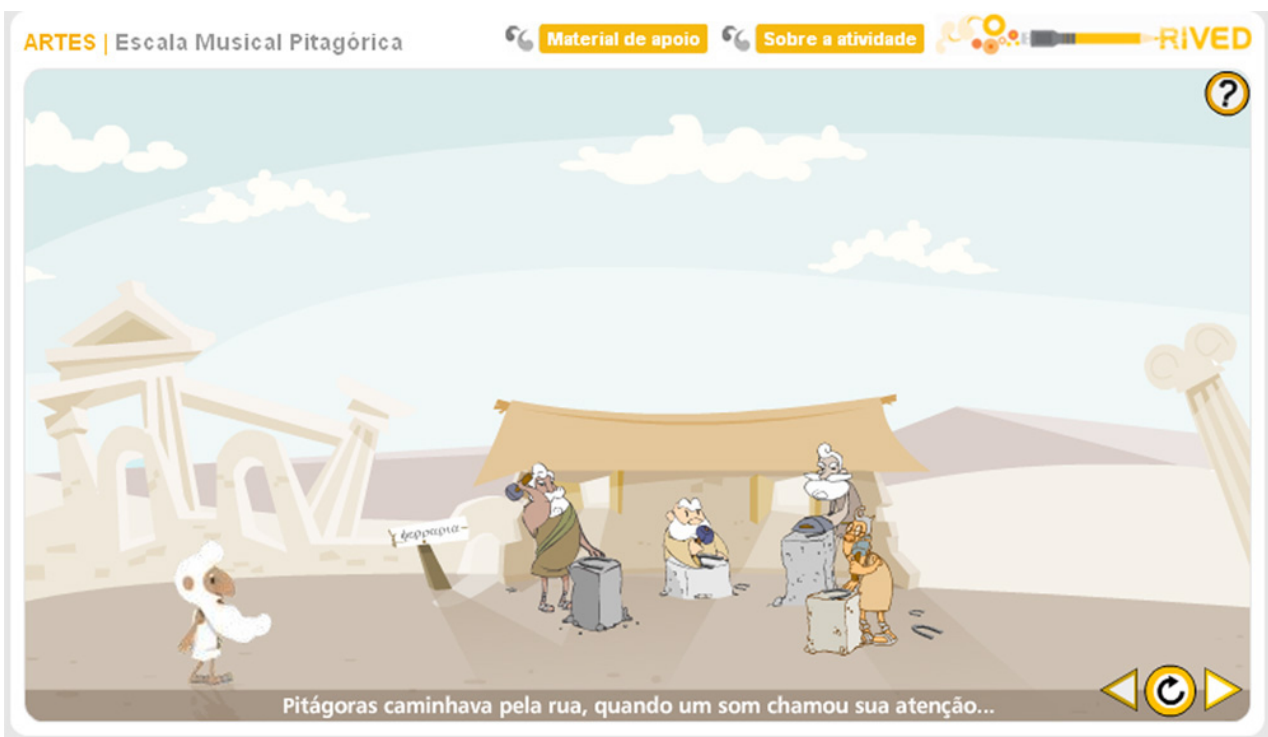

Figura 5.16 - Cena 2 


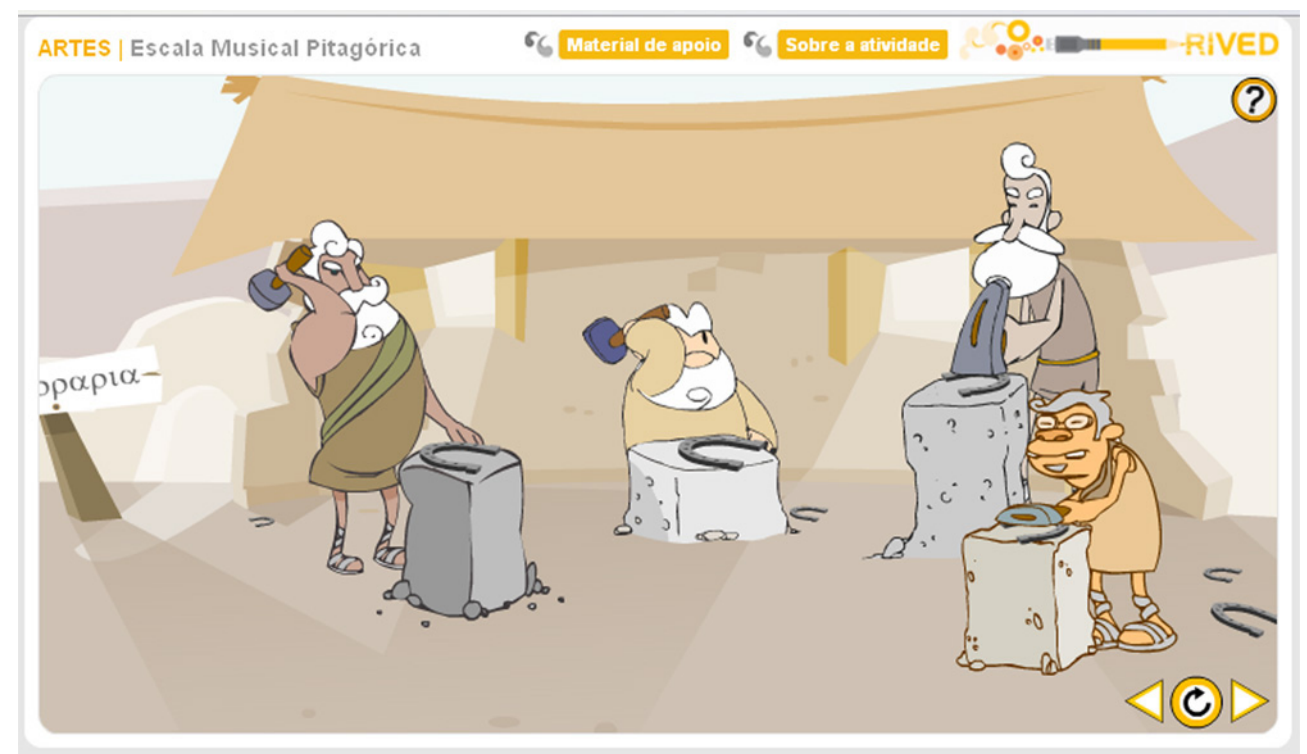

Figura 5.17 - Cena 3

A cena 4 foi acrescentada apenas com o objetivo de apresentar Pitágoras tendo a idéia do experimento proposto (martelos com pesos diferentes em cordas idênticas).

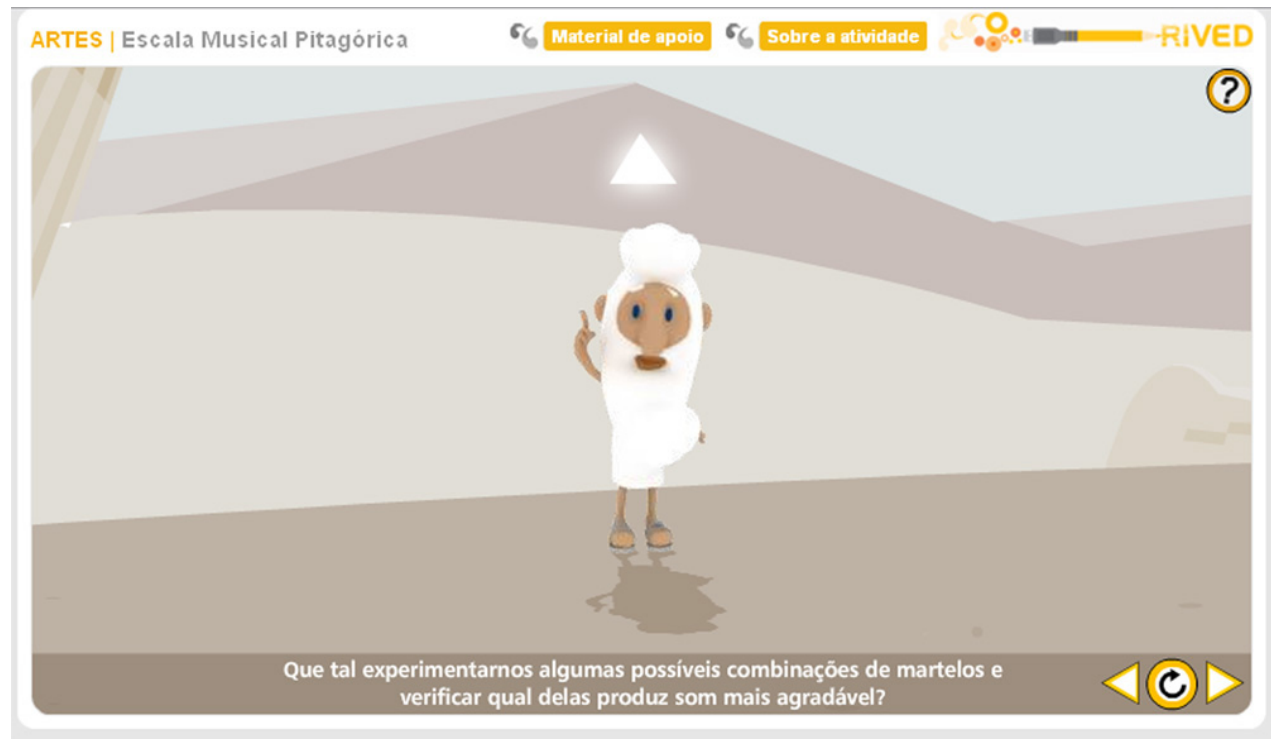

Figura 5.18 - Cena 4

A cena 5 está de acordo com storyboard e apresenta a parte interativa do objeto, onde o usuário escolhe o peso dos martelos, colocando-os nas respectivas cordas, com a intenção de testar o som produzido. 


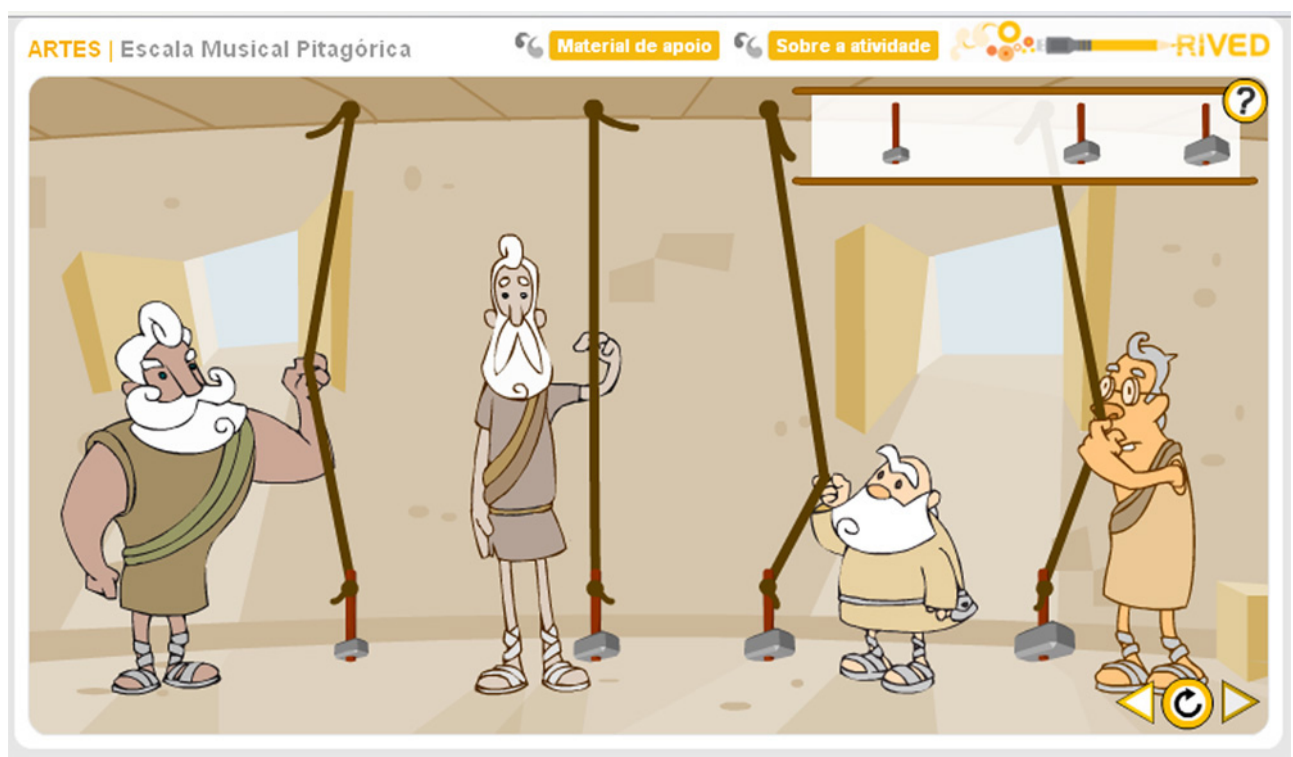

Figura 5.19 - Cena 5

Existem duas possibilidades para cena 6 :

No caso de erro, Pitágoras reclama do som produzido.

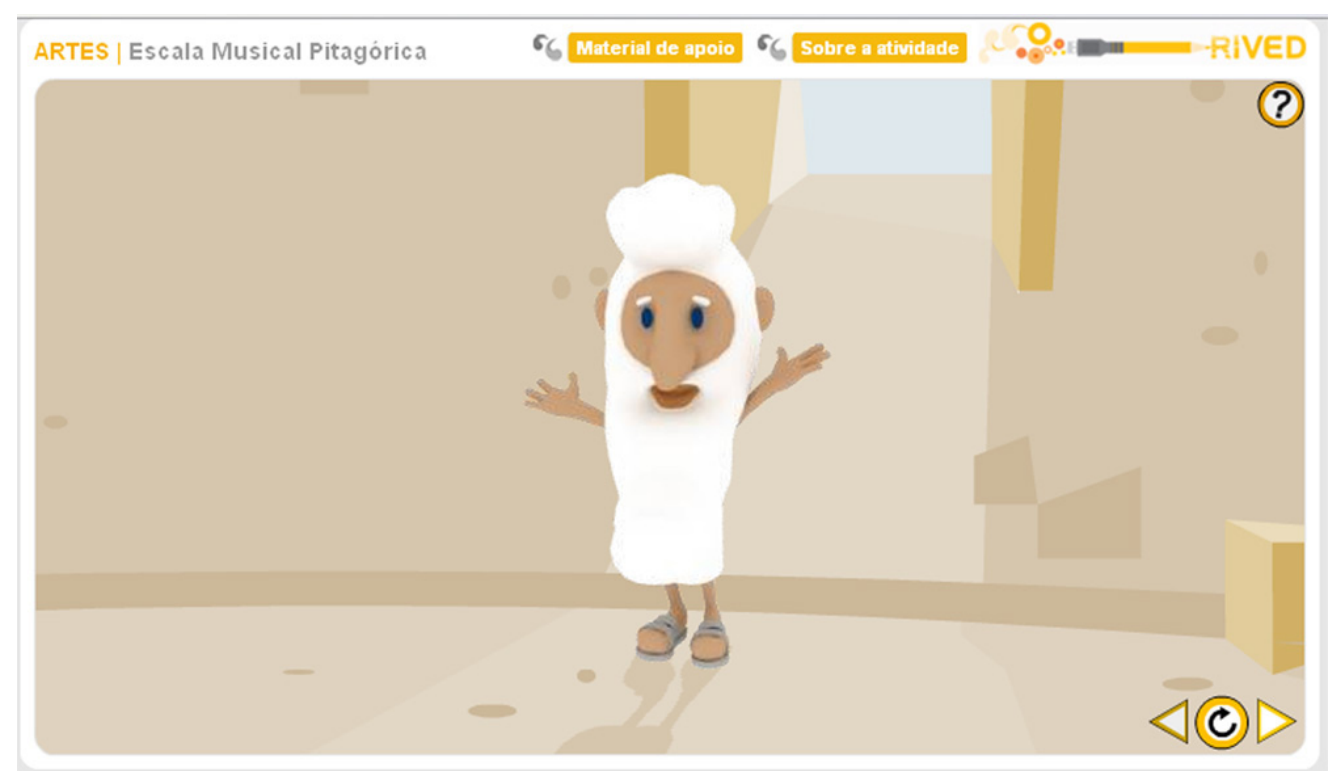

Figura 5.20 - Cena 6 - Erro 
No caso de acerto Pitágoras é aplaudido e agradece.

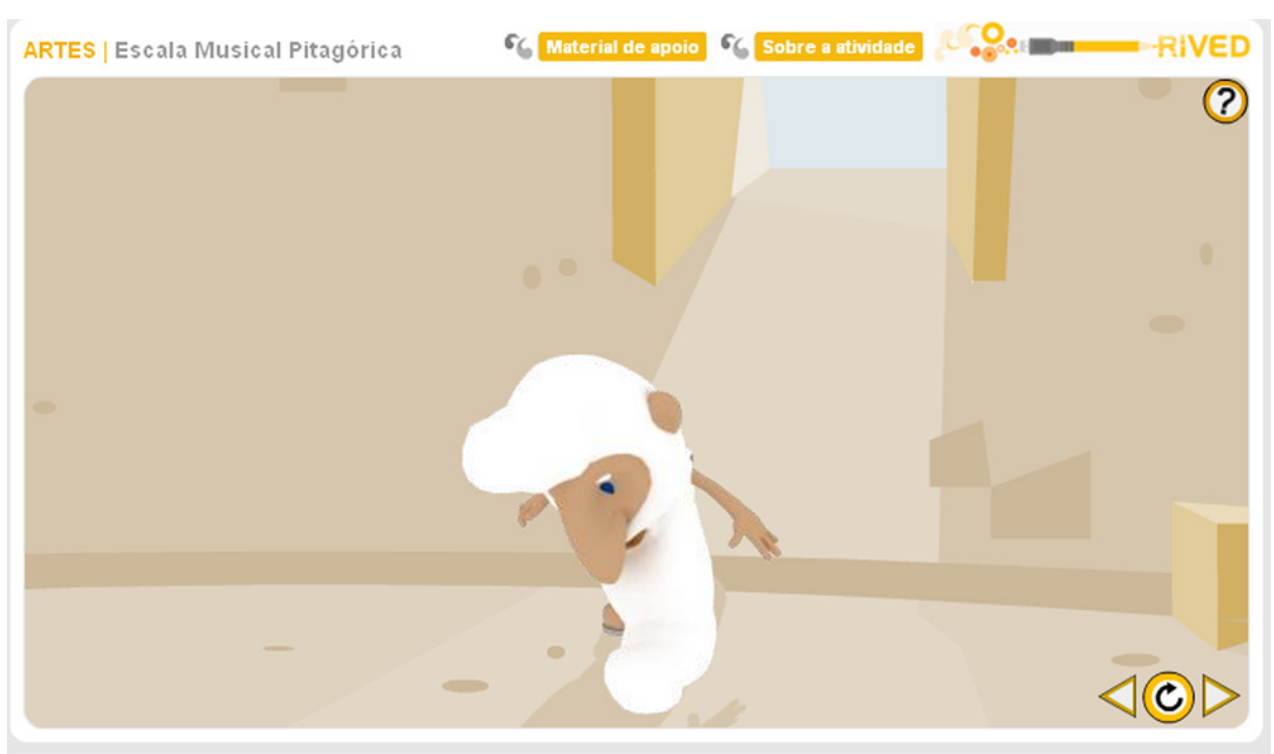

Figura 5.21 - Cena 6 - Acerto 


\section{Objeto 02 - Inércia}

Este segundo objeto de aprendizagem tem como objetivo levar o aluno a pensar sobre os primeiros conceitos de força. Passando pelo conceito aristotélico, em que a força é proporcional à velocidade, pelos questionamentos feitos por Galileu, responsável pela primeira contribuição à lei da inércia e, finalmente, pelo conceito newtoniano em que força é proporcional à variação da velocidade.

Para isto teremos uma pista de skate, em forma de $U$, onde o aluno fará a análise sobre as forças que atuam sobre o skatista.

O aluno poderá seguir duas linhas de raciocínio:

1- Raciocínio Aristotélico, onde a força é proporcional à velocidade, e com isto estando sempre presente se o corpo estiver em movimento.

2- Raciocínio Galileu-Newtoniano, onde a força é proporcional à variação da velocidade, atuando como agente de variação de velocidade, ou como força de equilíbrio, anulando uma possível variação provocada por outra força de mesmo valor e sentido contrário.

\subsection{Pesquisa e concepção dos personagens}

Para a produção do segundo objeto, seguiu-se a mesma metodologia do primeiro. Buscaram-se algumas imagens de referência para a elaboração dos conceitos dos cenários e dos personagens, sempre baseado no roteiro desenvolvido pelo orientador do conteúdo. Esse objeto possui três personagens principais: Galileu, Aristóteles e Newton. A partir de imagens e fotos, tentou-se reduzir a complexidade dos traços, com vistas a facilitar o processo de animação.

Foi usada a técnica de animação tradicional, ou seja, desenhos quadro a quadro, onde o usuário interage com um dos personagens, Galileu no caso, observando o que acontece em cena. A princípio, foram desenvolvidos alguns rascunhos baseados nas referências, simplificando o traço, sem perder as características principais de cada personagem. 

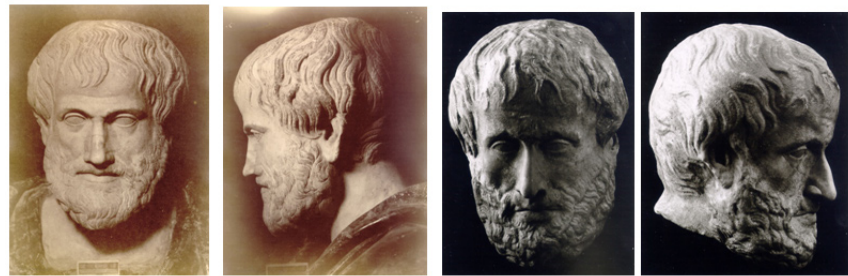

Figura 6.1 - Referência usada na concepção do personagem aristóteles

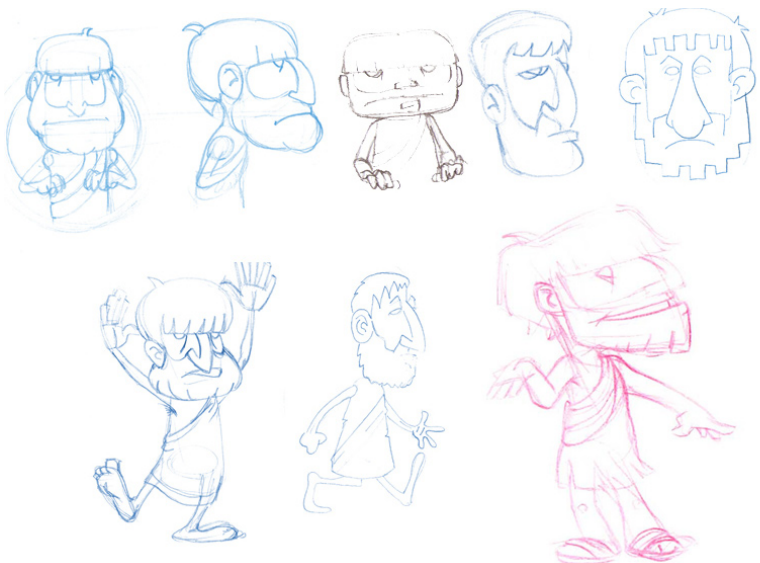

Figura 6.2 - Rascunhos para o personagem Aristóteles

Conceito do personagem - Aristósteles

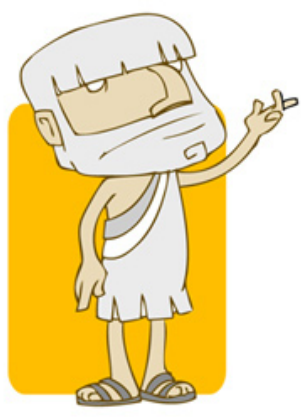

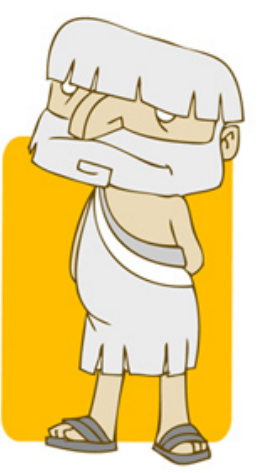
R: 235 G: 235 B: 235
R: 235 G: 220 B: 180
R: 205 G: 205 B: 205
R: $100 \mathrm{G}: 75$ B: 10
R: 140 G: 140 B: 140

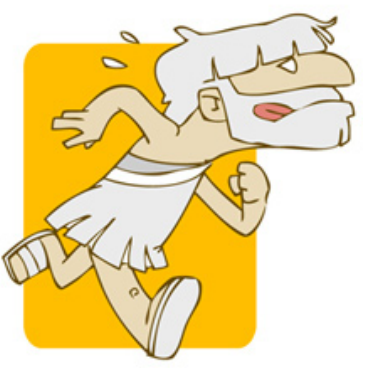

Figura 6.3 - Conceito do personagem Aristóteles

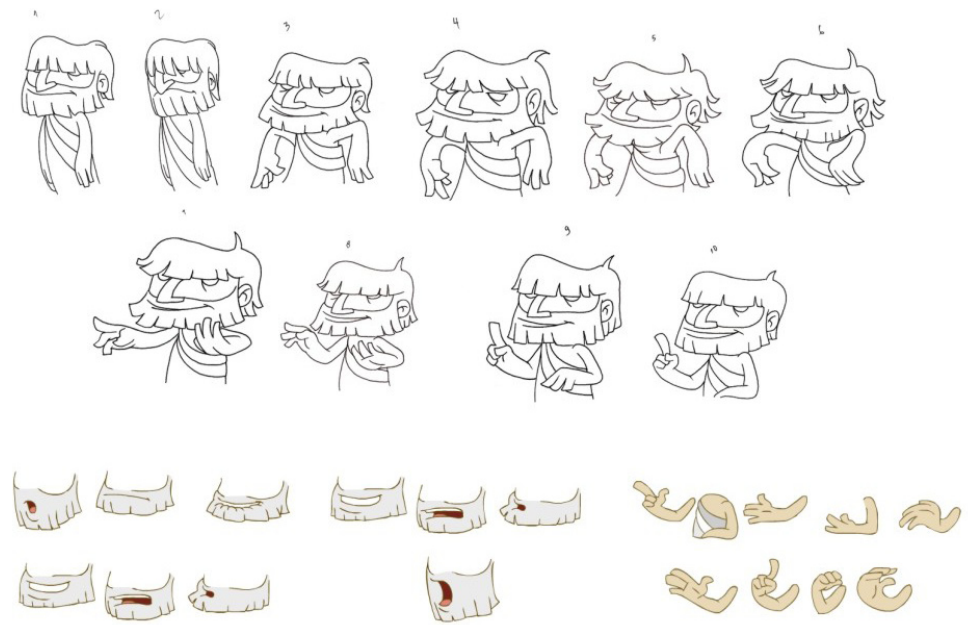

Figura 6.4 - Animação do personagem Aristóteles 


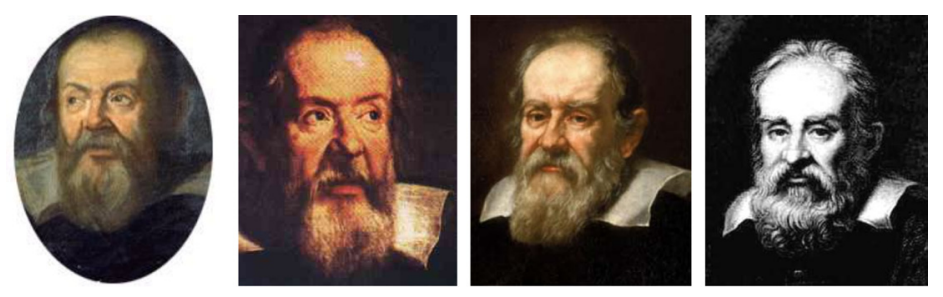

Figura 6.5 - Referências usadas na concepção do personagem Galileu
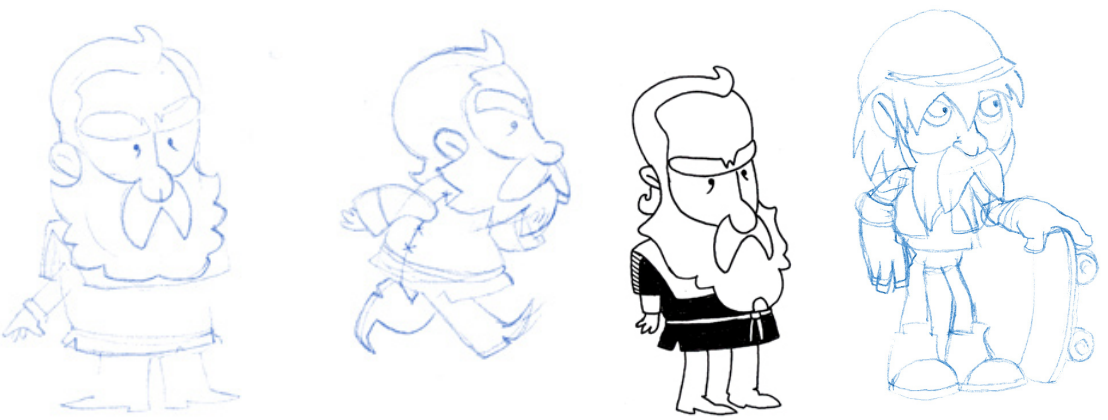

Figura 6.6 - Rascunhos para o personagem Galileu

Conceito do personagem - Galileu
R: $200 \mathrm{G}: 150 \mathrm{B:} 95$
R: $205 \mathrm{G}: 80 \mathrm{~B}: 0$
R: 240 G: 175 B:0
R: $100 \mathrm{G}: 75 \mathrm{~B}: 10$
R: 140 G: 105 B: 20
R: IIOG: 125 B: 150
R: $230 \mathrm{G}: 180$ B: 130

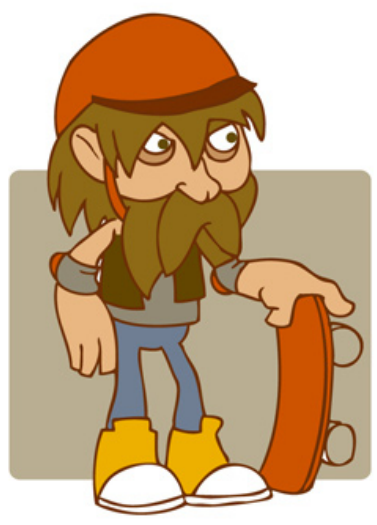

Figura 6.7 - Conceito do personagem Galileu
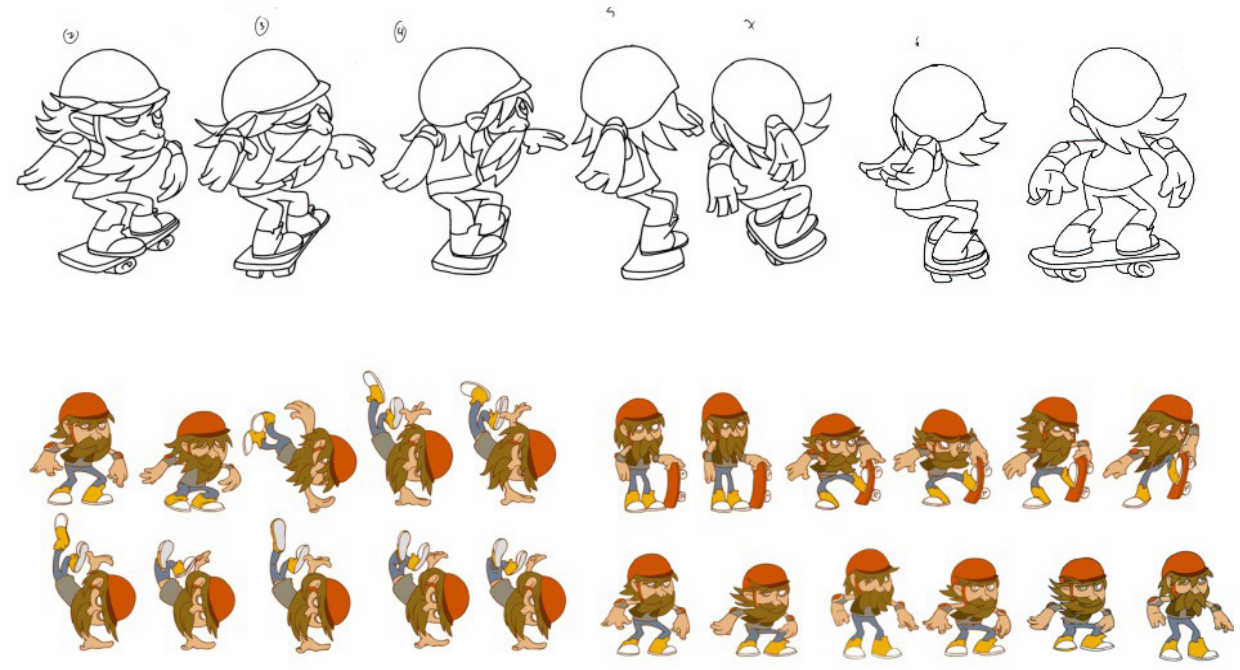

Figura 6.8 - Animação do personagem Galileu 

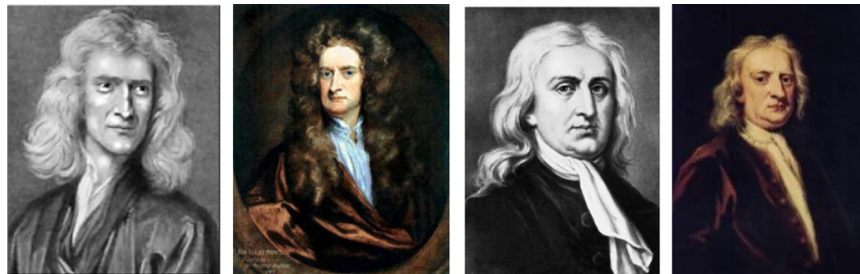

Figura 6.9 - Referências usadas na concepção do personagem Newton

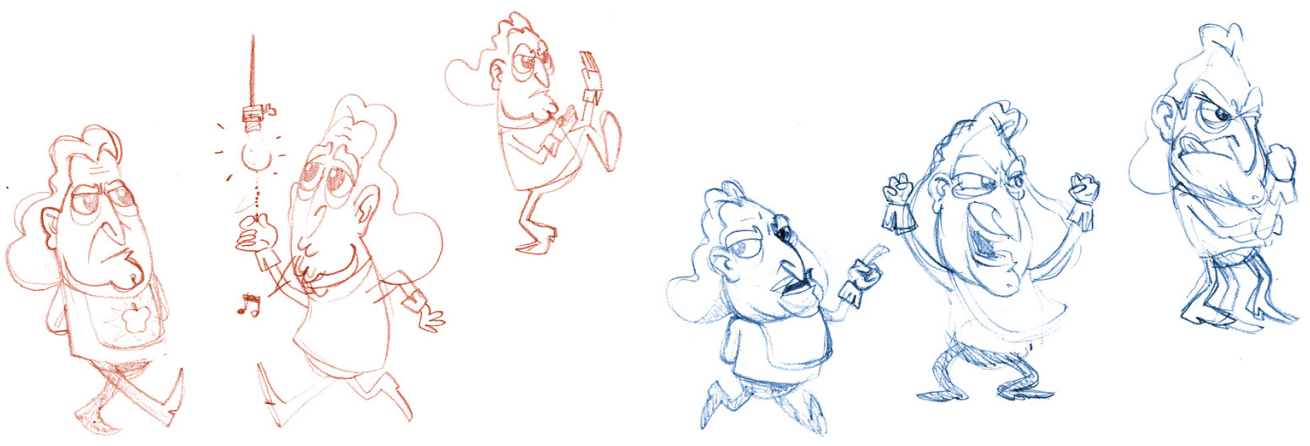

Figura 6.10 - Rascunhos para o personagem Newton

Conceito do personagem - Newton
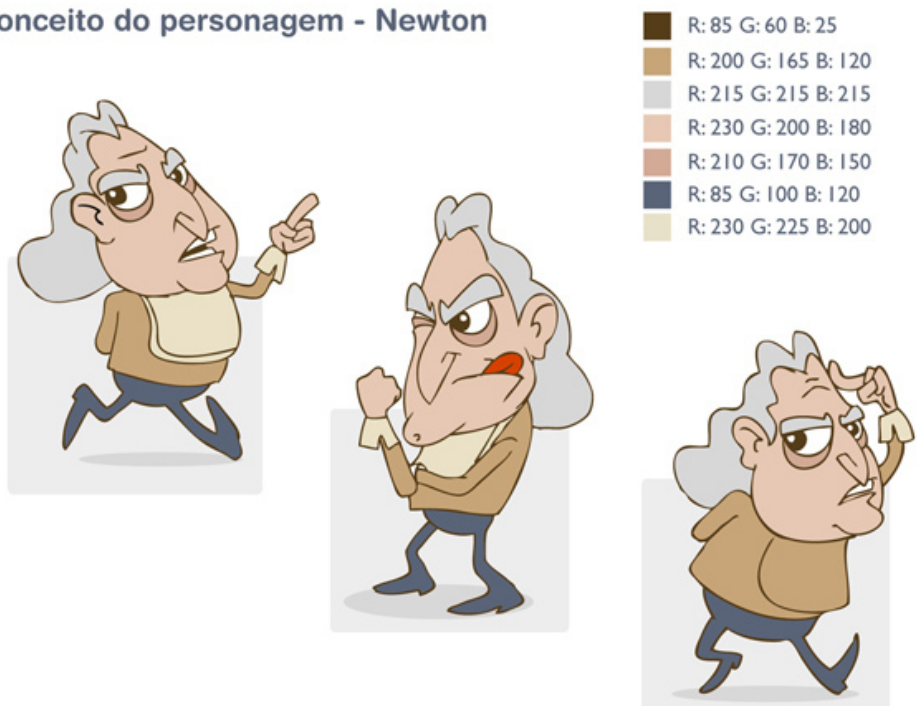

Figura 6.11 - Conceito do personagem Newton
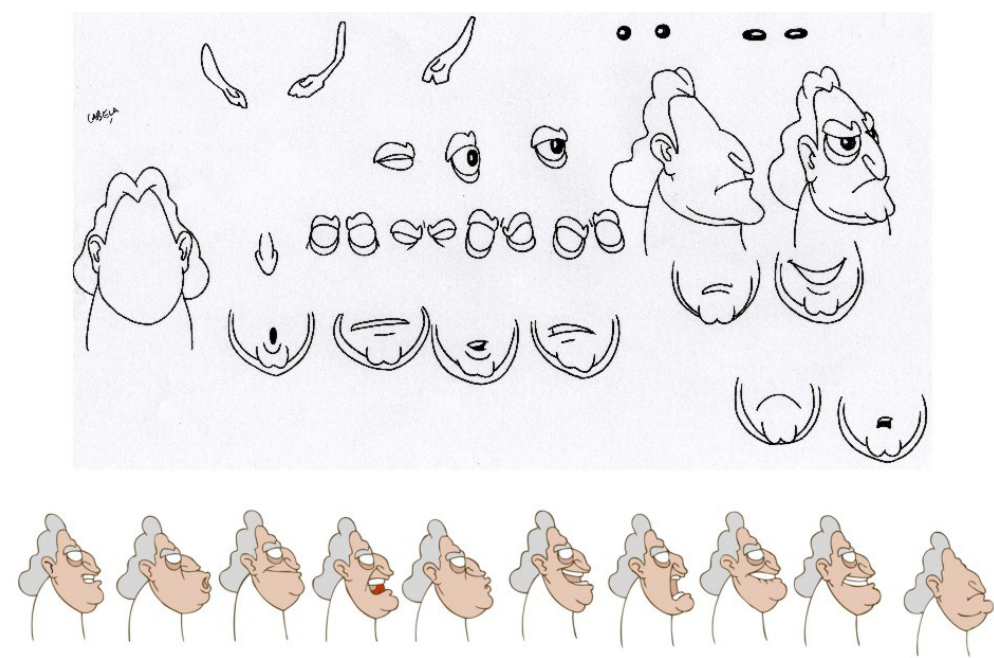

Figura 6.12 - Animação do personagem Newton 


\subsection{Cenário}

A estética do cenário foi definida de acordo com os dados contidos no roteiro. A idéia do objeto de aprendizagem é simular um personagem realizando manobras no skate, enquanto são analisados alguns fenômenos físicos descritos pelos personagens principais, Newton e Aristóteles. A concepção do cenário foi desenvolvida em um software tridimensional, com a técnica do box modelling (subdivisão de polígonos).
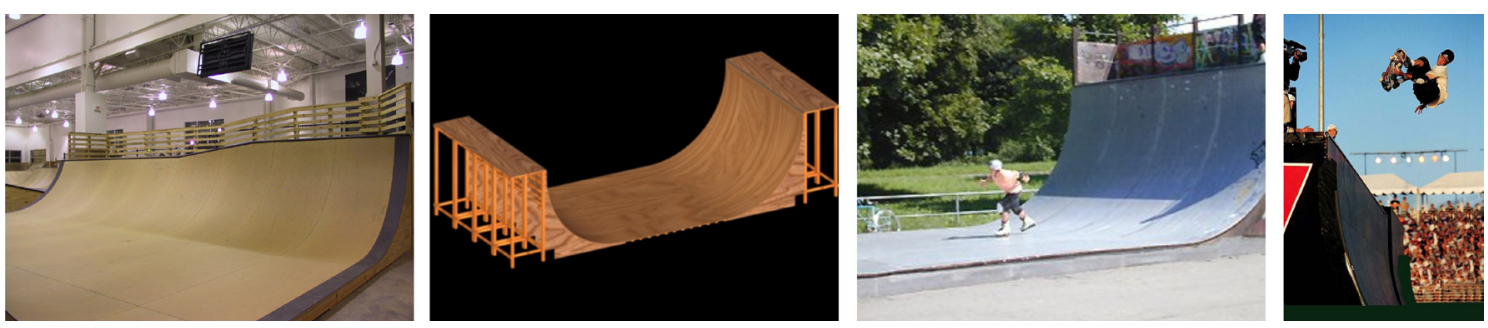

Figura 6.13 - Referência usada na concepção do cenário

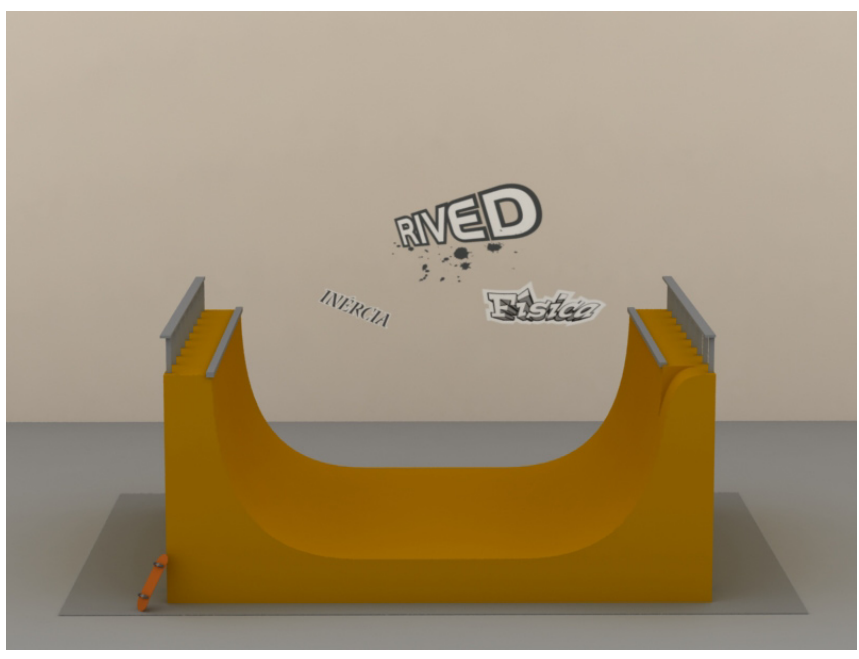

Figura 6.14 - Cenário desenvolvido para interagir com os personagens 2D

\subsection{Objeto de aprendizagem final aplicado ao padrão HTML}

Nesta atividade o intuito é fazer com que o usuário participe de um debate com o objetivo de investigar os argumentos apresentados pelos personagens, verificando sua veracidade, baseando-se em observações e conclusões de senso comum.

\section{Tela 1}

Rampa em U com o skatista "Galileu" fazendo algumas manobras e texto com a fala do personagem. A tela inicial possui uma breve introdução sobre o funcionamento da atividade. 


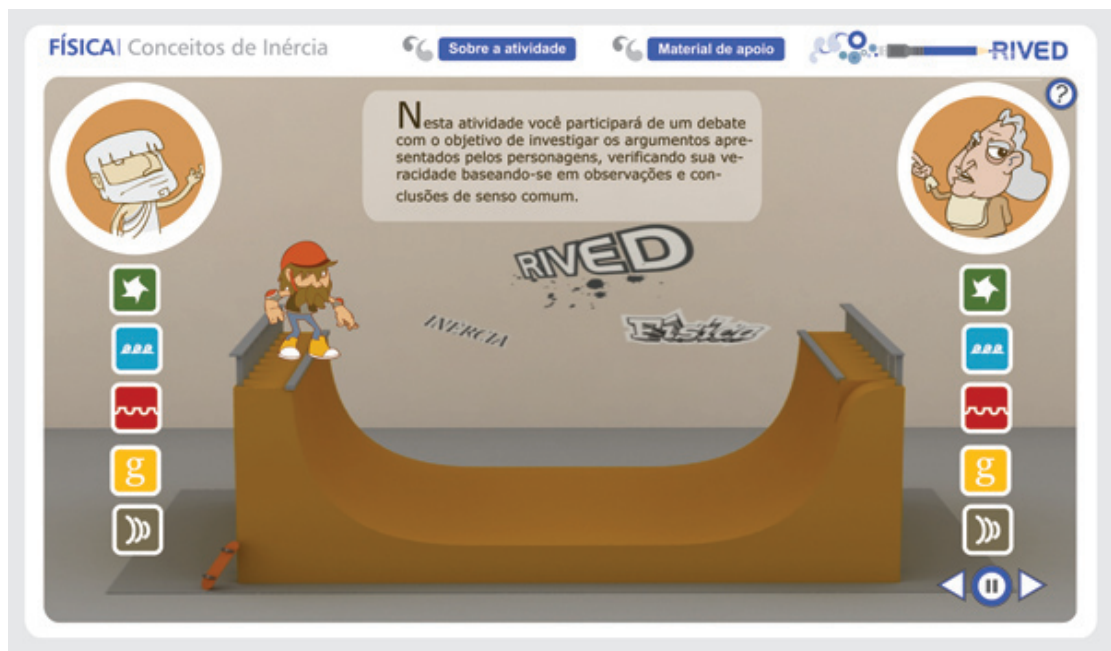

Figura 6.15 - Tela 1

\section{Tela 2}

Fala do narrador:

"Qual é a causa de cada movimento? É isso que eu preciso para compreender o que está acontecendo em cada manobra!!!

- será que você poderia me ajudar?”.

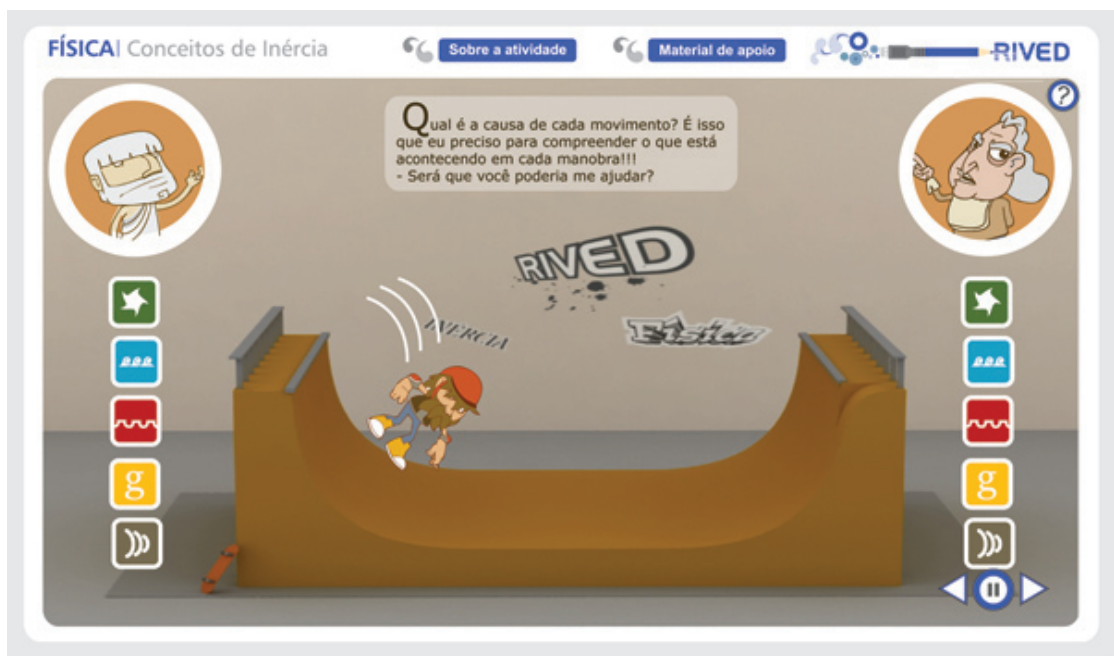

Figura 6.16 - Tela 2

\section{Tela 3}

Aristóteles e Newton, com seus respectivos ícones.Aparece na mesma tela uma orientação indicando o que usuário deverá fazer para seguir adiante.

Narrador:

"Escolha no menu abaixo os ícones que representem melhor as causas do movimento em cada manobra." 


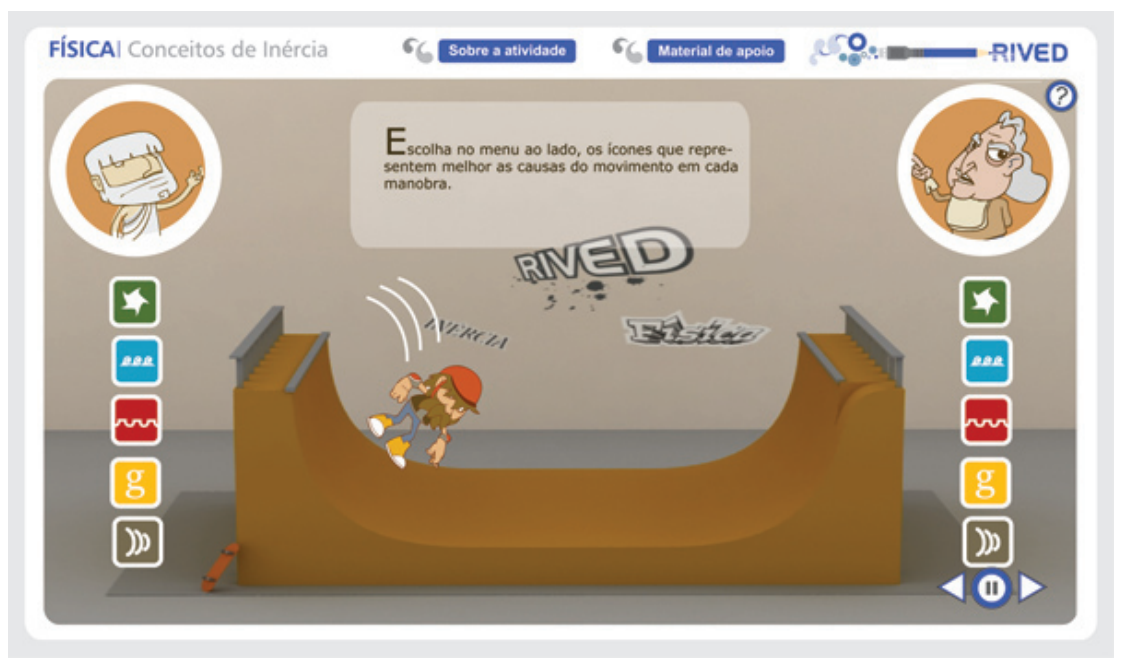

Figura 6.17 - Tela 3

\section{Tela 4}

Nesta tela os ícones aparecem com seus respectivos significados.

\section{Ícones de Aristóteles}

1 - Movimento natural:

Causa do movimento vertical, fazendo com que um corpo, composto por elementos terra e água predominantemente, retorne sempre ao seu lugar natural, à superfície da Terra.

2 - Movimento antiperistáltico.

Mecanismo que funciona como um motor para o movimento, onde o ar atua como agente responsável pela manutenção do movimento.

3 - Atrito com o chão:

Representado por um botão que possa alterar seu valor gradativamente.

4 - Variação da quantidade de ar:

Representado por um botão que possa alterar seu valor gradativamente.

5 - Força horizontal (aplicada com o pé).

\section{Ícones de Newton}

1 - Força gravitacional:

Força vertical, dirigida radialmente para o centro Terra, sendo aproximadamente paralela na superfície, responsável pela aceleração " $g$ " dos corpos nas vizinhanças da superfície da Terra.

2 - Inércia:

Propriedade dos corpos de conservarem seu movimento sem nenhuma força atuando. 
3 - Atrito com o chão:

Representado por um botão que possa alterar seu valor gradativamente.

4 - Variação da quantidade de ar:

Representado por um botão que possa alterar seu valor gradativamente.

5 - Força horizontal (aplicada com o pé).

Em determinados pontos da pista, Galileu pára e faz algumas perguntas sobre as causas do movimento e o movimento só ocorre quando o aluno escolhe uma das opções. O aluno clica sobre as opções que caracterizarão as causas do movimento em cada ponto da pista.

\section{Possibilidades para a questão 1}

Se o aluno acionar o ícone "força horizontal" o movimento acontece.

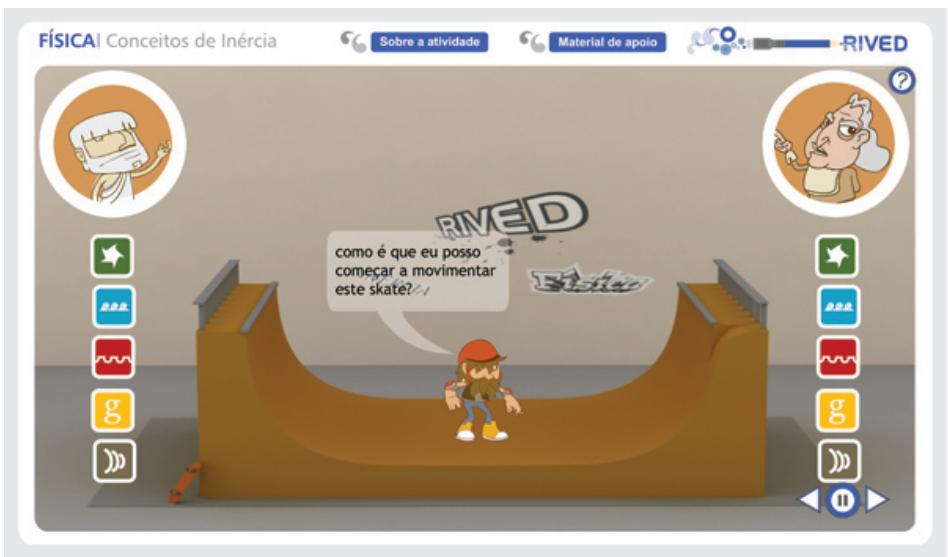

Figura 6.18 - Questão 1

\section{Possibilidades para a questão 2}

Se o aluno acionar o ícone "força horizonta" o skatista desloca-se um pouco e em seguida cai, qualquer outra resposta "explica logicamente" a causa do movimento, portanto o movimento acontece.

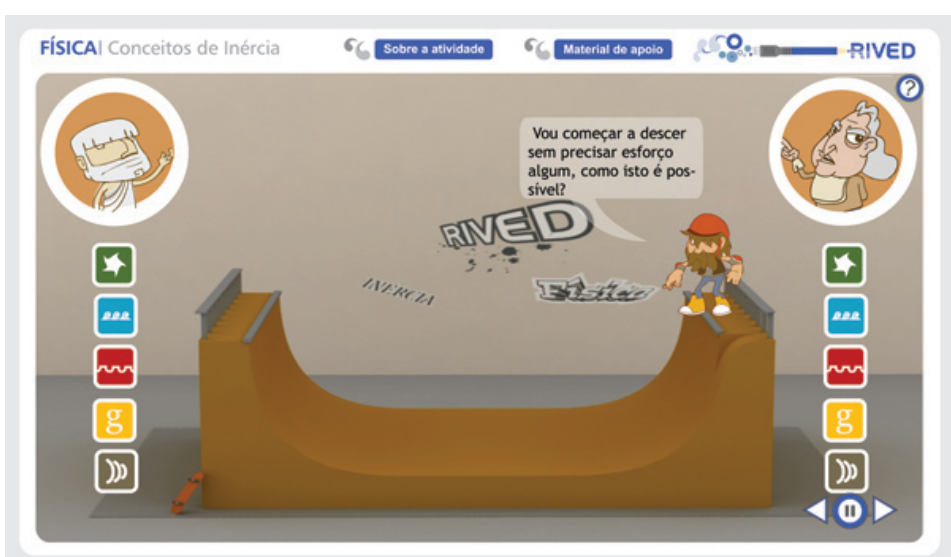

Figura 6.19 - Questão 2 


\section{Possibilidades para a questão 3}

Qualquer resposta está correta, menos a "força horizontal" que leva o skatista Galileu a uma queda.

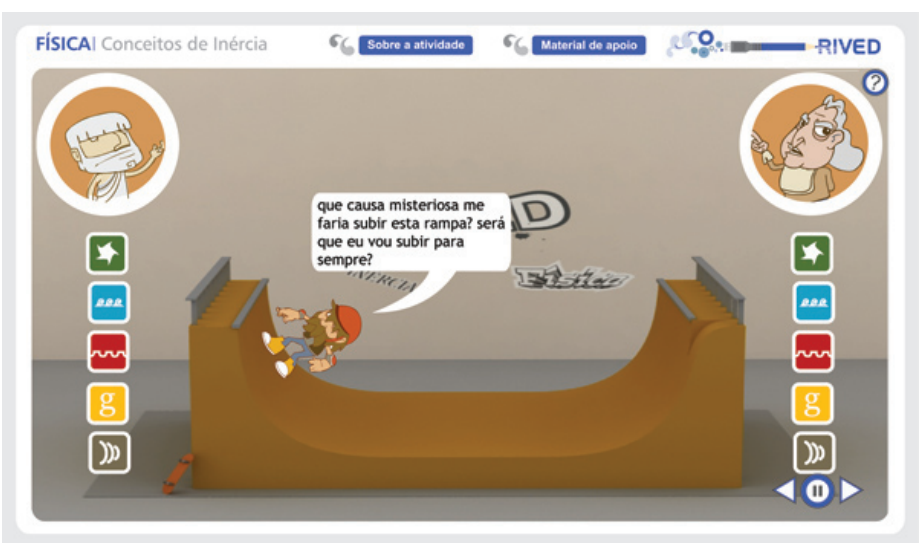

Figura 6.20 - Questão 3

\section{Possibilidades para a questão 4}

Neste caso, a opção "força horizontal" não estará disponível. Inicialmente as opções "inércia" e "antiperístase" serão consideradas corretas, mas a partir deste momento torna-se disponível também o ícone "quantidade de ar", que o aluno então será sugerido a alterar e verificar o que acontece para os dois casos. Finalmente, o aluno será levado a comparar, analisar e concluir sobre a explicação correta para o movimento horizontal, variando o atrito com o chão e a interação com o ar.

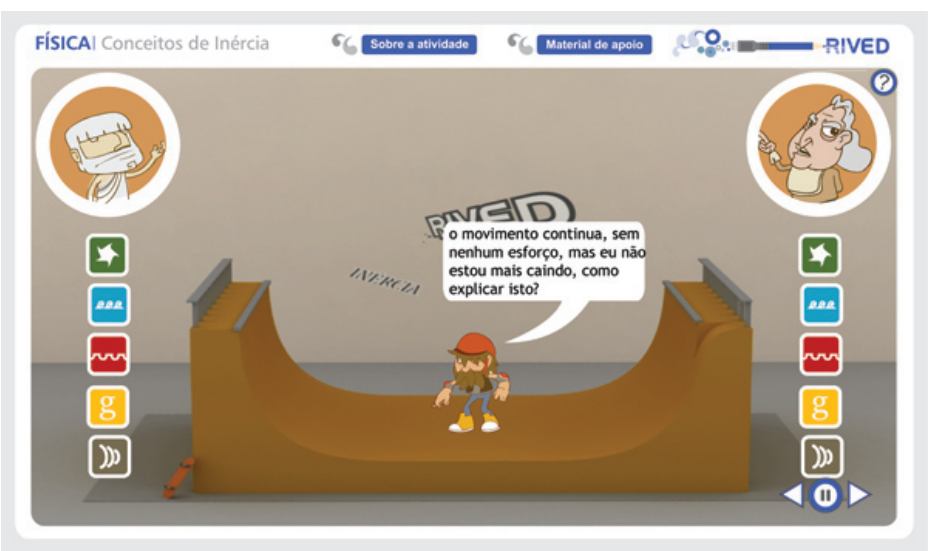

Figura 6.21 - Questão 4 


\section{Conclusão}

O projeto em questão tratou do desenvolvimento de um trabalho de intervenção no design dos padrões dos módulos do RIVED, e criou dois novos objetos de aprendizagem nas áreas de Física e Arte. No entanto, os objetos projetos requerem ainda a validação prática junto ao usuário. Após esta validação o projeto deverá ser apresentado ao RIVED como forma de contribuir com a melhoria da qualidade de seus módulos e objetos de aprendizagem futuros, do ponto de vista da programação visual.

O resultado final do projeto aqui apresentado demonstrou a importância e necessidade do trabalho do designer no desenvolvimento de uma interface gráfica. Torná-la mais atrativa e lúdica para o usuário, assim como eficiente, eficaz e satisfatória do ponto de vista da usabilidade, foram alguns dos objetivos alcançados. O padrão HTML proposto pelo RIVED recebeu a partir da concepção deste projeto um tratamento estético (ilustração coerente com o estilo do usuário e valorização da limpeza visual) juntamente com a valorização de seu aspecto funcional. Todo o conteúdo do módulo foi colocado em apenas uma página, a área do palco para as animações foi maximizada, os dois principais links (sobre a atividade e material de apoio) passaram a ser acessados a qualquer momento da atividade, maior destaque aos links, etc. Da mesma forma, os botões de navegação das animações, além de ficarem mais intuitivos, ocuparam uma área menor do palco. As ilustrações das animações foram concebidas com a preocupação de ficarem de acordo com a faixa etária do usuário. O padrão desenvolvido prevê um maior controle do usuário sobre a navegação, uma vez que pode avançar, voltar e reiniciar a atividade a qualquer momento, o que não ocorria nos objetos analisados neste estudo. Vale ressaltar que as padronizações concebidas estão de acordo com os requisitos estabelecidos pelo projeto.

O resultado satisfatório do trabalho do designer depende do equilíbrio entre os fatores estéticos e funcionais dentro de um contexto definido. Cabe ao designer conhecer este contexto para então definir as ferramentas para a realização do projeto.

Não existe apenas uma solução válida para este projeto, porém qualquer solução baseada nos requisitos aqui estabelecidos tende a produzir resultados eficazes. Um trabalho com esta complexidade dificilmente poderia atingir um resultado satisfatório baseado em decisões arbitrárias. Esta é a falha da metodologia proposta pelo RIVED - não incluir no processo de elaboração de um objeto de aprendizagem um especialista na área de programação visual.

Finalizando, deve-se ressaltar que o Prof. de Física Flávio Ambrósio Campos participou de todo o processo de criação do objeto de aprendizagem juntamente com a equipe de designers e constatou a relevância do trabalho realizado e a necessidade de aperfeiçoamento futuro do programa RIVED. 


\section{Referências bibliográficas}

Abergo. Associação brasileira de ergonomia. Disponível em: < http://www. abergo.org.br/oqueeergonomia.htm > Acesso em: nov. 2006

ABRAHAN, Julia Issy; SARMET, Maurício Miranda; SILVEIRA, Alexandre Magno Dias. Ergonomia, cognição e trabalho informatizado. v.21, n.2, p.163-171. Instituto de Ciências do Trabalho - Universidade de Brasília

BAXTER, Mike.Projeto de Produto. 2.ed. Edgar Blucher, 2003

BRUNETTI, Maria Elizabeth. Sobre um juízo estético peculiar à educação do designer. Revista Diálogo Educacional. v.1, n.1, jun. 2000, p.1-95

BRINGHURST, Robert. Elementos do estilo tipográfico. 3.ed.

FILATRO, Andréia Cristina. Design instrucional contextualizado: educação e tecnologia, Disponível em: < http://icisc.neasist.org/about.html\#is > Acesso em: 1 out. 2006.

FRUTIGER, Adrian. Sinais e símbolos: desenho, projeto e significado. São Paulo: Martins Fontes, 2001.

GAMBARATO, Renira Rampazzo; MALAGUTI, Simone. Objetos do desejo de Win Wenders. Revista Digital Art. ano III, n.4, out. 2005.

GRUSZYNSKI, Ana Cláudia. Design Gráfico: entre o invisível e o ilegível. Rio de Janeiro: PUC, 2000.

KRUSSER, Renata; GEREMIAS, Marco Aurélio. Design de interface para educação on-line Design de interface para educação no ciberespaço. Laboratório de Hipermídia - Universidade do Estado de Santa Catarina, Florianópolis, jun. 2004.

LIMA, Sérgio Luis dos Santos. Ergonomia Cognitiva e a Interação PessoaComputador: Análise da Usabilidade da Urna Eletrônica 2002 e do Módulo Impressor Externo, Dissertação de Mestrado, Florianópolis, 2003.

NASCIMENTO, Anna C; MORGADO, Eduardo. Um projeto de colaboração Internacional na América Latina. DEIED / SEED / MEC. Disponível em: < http://rived.proinfo.mec.gov.br/projeto.php > Acesso em: 28 set. 2006

PETIT, Paul. História antiga, 3.ed. Difel.

RIBEIRO, Milton. Planejamento Visual gráfico. 7.ed. LGE 
PATRICK. Subdivision modeling. Artigos sobre modelagem 3D. Disponível em: < http://www.subdivisionmodeling.com/wiki/tiki-index.php?page=What+is+subdivision+modeling > Acessado em: 10 out. 2006.

WILEY, D. A. Connecting learning objects to instructional design theory: A definition, a metaphor, and a taxonomy. In D. A. Wiley (Ed.), The instructional use of learning objects. p.1-35. 2000 